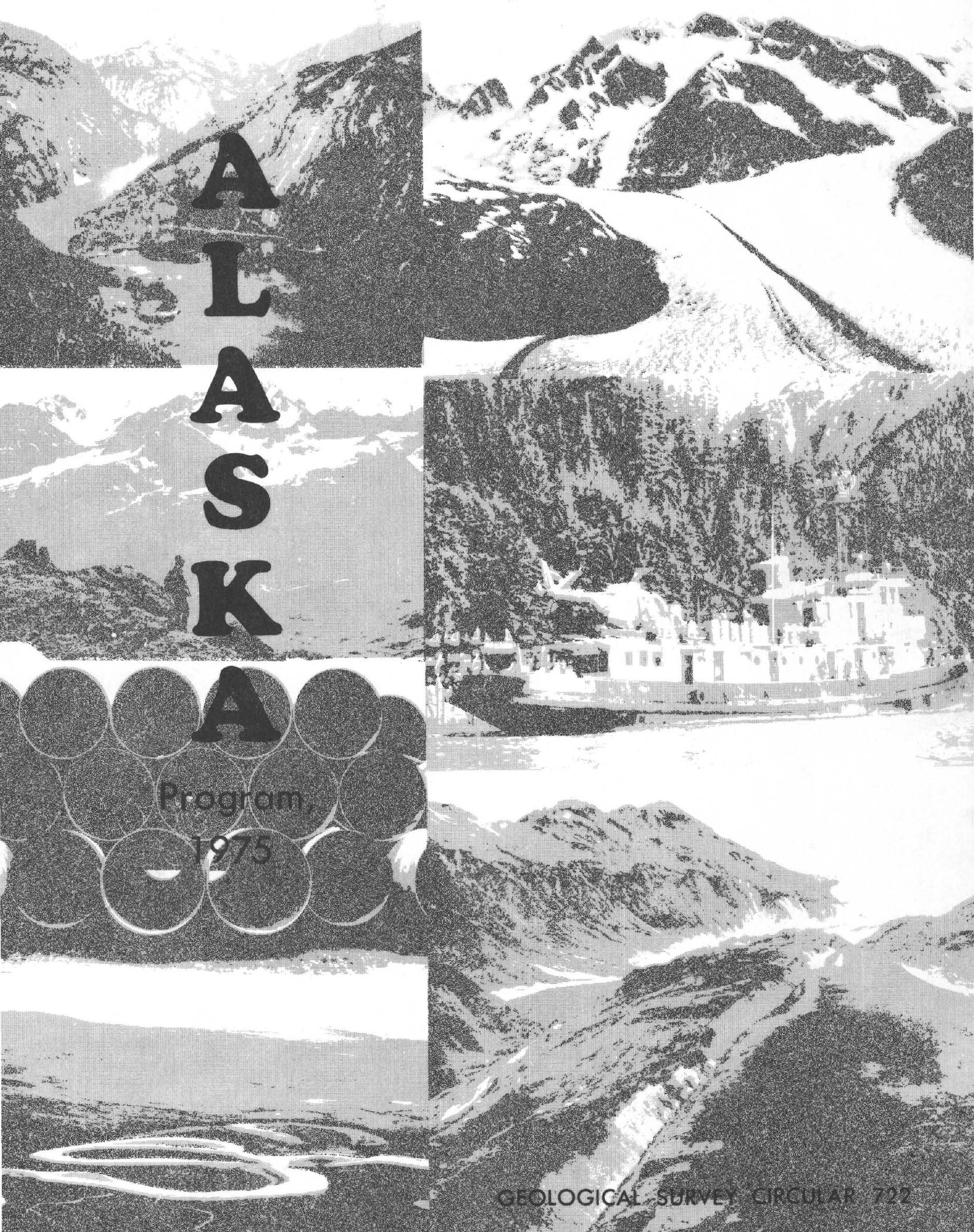





\section{United States Geological Survey Alaska Program, 1975}

By M. E. Yount, Editor

GEOLOGICAL SURVEY CIRCULAR 722 


\section{United States Department of the Interior}

STANLEY K. HATHAWAY, Secretary

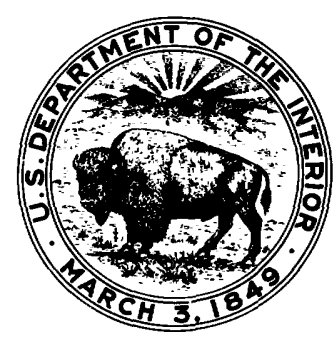

\section{Geological Survey}

V. E. McKelvey, Director

Library of Congress catalog-card No. 75-600064 


\section{CONTENTS}

\begin{tabular}{|c|c|c|c|}
\hline & Page & & \\
\hline & 1 & Alaskan projects of the U.S. Geological Survey-Con. & \\
\hline ervices of the United States Geological Survey & 1 & Projects with regional emphasis-Continued & \\
\hline Introductic & 1 & Southwestern Alaska & \\
\hline ities of the Geological Survey -. & 1 & Southern Alaska & 22 \\
\hline Organizati & 3 & Southeastern Alaska & 27 \\
\hline Orgar & 6 & Cooperative projects with other agencies & \\
\hline ision & 6 & Statewide projects & \\
\hline & 6 & East-central Alaska & \\
\hline sion & 7 & Southern Alaska ...... & \\
\hline Wa & 8 & Alaska & \\
\hline Pub & 8 & Summary of important results, 1974 & \\
\hline Ad & 9 & Statewide & \\
\hline & 9 & $\mathrm{~N}$ & \\
\hline 1 and rescue & 9 & ska... & \\
\hline $\operatorname{Rad}$ & 9 & West-central Alaska & \\
\hline 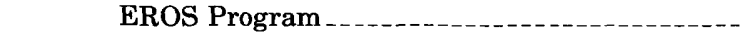 & 9 & Southwestern Alaska & \\
\hline Alaskan proj & 10 & Southern Alaska & \\
\hline Statew & 10 & Southeaster & \\
\hline Projects with regional emphasis & 13 & References cited in summary of important results & \\
\hline Northern Alaska & 13 & 1974 & \\
\hline East-central Alaska & 18 & Reports on Alaska published by U.S. Geological Surve & \\
\hline West-central Alaska & 19 & in 1974 & \\
\hline
\end{tabular}

\section{ILLUSTRATIONS}

1. Organization of the U.S. Geological Survey

2. Organization of the Geo

3. Organization of the Conservation Division

4. Organization of the Water Resources Division

5. Organization of the Topographic Division

6. Map showing locations of 1975 field projects of the U.S. Geological Survey

7-12. Photographs:

7. A well-developed pingo near Inuvik, Canada

8. A wood-stave pipeline in the Seward Peninsula

9. The Alsek-Grand Plateau fault cuts a moraine in the Skagway A-8 quadrangle

10. Field camp on the Juneau Icefield

11. Lack of outcrop on the Juneau Icefield

12. $R / V$ Don J. Miller II provides support for fieldwork in watery southeastern Alaska ______ 29

13. Map showing locations of 1975 field projects of the U.S. Geological Survey and cooperating agencies _-_-_-_-- 30

14. Photograph showing stream gaging in Alaska

15. Map showing locations of studies discussed in the summary of important results, 1974

16-18. Photographs:

16. Valley of the Anaktuvuk River looking southwest to Anaktuvuk Pass _-_ 40

17. Augustine Island approximately 185 miles southwest of Anchorage

18. The Narrows at the entrance to Fords Terror, Tracy Arm-Fords Terror Wilderness Study

area -

19. Map showing aeromagnetic coverage for the State of Alaska 


\section{United States Geological Survey Alaska Program, 1975}

M. E. Yount, Editor

\section{ABSTRACT}

This report on the Alaskan activities of the U.S. Geological Survey contains up-to-date accounts of recent results and summaries of plans for the summer of 1975. It is organized in six parts: (1) responsibilities and services of the Geological Survey; (2) organization of the U.S. Geological Survey; (3) U.S. Geological Survey Alaskan field activities for 1975 ; (4) cooperative projects with State and Federal agencies; (5) summary of important results of geological, hydrological, and geophysical research in 1974; and (6) reports published by Survey authors in 1974 .

\section{SERVICES OF THE UNITED STATES GEOLOGICAL SURVEY}

\section{INTRODUCTION}

This report on the Alaskan activities of the United States Geological Survey is for the many people and groups deeply interested in Alaska. For the professional geologist, hydrologist, or topographer, for example, it contains up-to-date accounts of recent results and summaries of plans for the summer of 1975. For various private groups, the business community, and other Federal and State agencies, there is news of investigations that is intended to assist them in their separate and important tasks. And for the citizen, whose pleasure and livelihood are linked to the natural surroundings, the report is an introduction to our studies of the land and water of the incomparable State of Alaska.

To reach such a complex audience, this circular is organized into six parts. In this introductory section the responsibilities and services of the Geological Survey are discussed. The second section presents the organizational structure of the Survey, as well as a discussion of the organizational segments serving Alaska. The third and fourth sections together are a comprehensive listing of Alaskan summer field activities for 1975, with section three describing Survey projects and section four detailing cooperative projects between the Survey and other Federal and Alaskan state agencies. The fifth section, a summary of the more important results of last year's geological, geophysical, and hydrological research, complements the sixth section, a list of reports put lished by Survey authors in 1974 .

\section{RESPONSIBILITIES OF THE GEOLOGICAL SURVEY}

The U.S. Geological Survey serves the needs of the citizens and their government for information on the land and water of the United States. This information is obtained and analyzed by U.S.G.S. scientists and is distributed to the pul lic in the form of maps and reports. Most maps and reports are published by the government and current publications are announced by means of monthly notices, "New Publications of the Geolorical Survey," which are free on application to th: Geological Survey, Reston, Va. 22092. Book publications may be ordered from either of the following places:

Branch of Distribution
U.S. Geological Survey
1200 South Eads Street
Arlington, Va. 22202

Superintendent of Documents Government Printing Office

Washington, D.C. 20402

Maps may be ordered from the followirg places:

Branch of Distribution, Central Rexion

U.S. Geological Survey

Federal Center

Denver, Colo. 80225 
Alaska Distribution Section

U.S. Geological Survey

310 First Avenue

Fairbanks, Alaska 99701

Maps may also be purchased over the counter from the U.S. Geological Survey, Water Resources Division, 441 Federal Bldg., 710 West Ninth St., Juneau, Alaska 99801 and the U.S. Geological Survey, Public Inquiries Office, 108 Skyline Bldg., 508 Second Ave., Anchorage, Alaska 99501. Book publications on Alaska are also available from the Public Inquiries Office in Anchorage.

Some studies, especially those of high scientific merit, are published in professional journals; these are available at college, industrial, and possibly public libraries.

The scope of Alaskan studies is broad and is probably best illustrated by example. Thus the list that follows contains a selection of recent Geological Survey maps and reports accompanied by a brief explanation of what they disclose and how they may be used.

Reference: Beikman, H. M., 1974, Preliminary geologic map of the southwest quadrant of Alaska: U.S. Geol. Survey Misc.

Field Studies Map MF-611, 2 sheets, scale 1:1,000,000.

Available from: Denver Distribution Section, U.S. Geological

Survey, Federal Center, Denver, Colo. 80225; $\$ 1.00$.

The map shows the distribution of rock types and faults in the entire southwestern quarter of Alaska. It can be used for many purposes, especially as an aid in locating valuable mineral commodities.

Reference: Cobb, E. H., 1974, Geological Survey published reports on Alaska, 1960-1973, indexed by quadrangle: U.S. Geol. Survey open-file report 74-210, $166 \mathrm{p}$.

Available from: Alaskan Technical Data Unit, U.S. Geological Survey, 345 Middlefield Road, Menlo Park, Calif. 94025.

This report is one of a series which indexes all U.S. Geological Survey publications and most U.S. Bureau of Mines and State publications by 1:250,000 quadrangle. These reports greatly facilitate research in the geologic literature of any particular geographic area of Alaska.

Reference: Berg, H. C., 1974, Geology of Gravina Island, Alaska: U.S. Geol. Survey Bull. 1373, 41 p.

Available from: Superintendent of Documents, Government Printing Office, Washington, D.C. 20402; $\$ 1.70$.

Gravina Island sits astride three of the major structural belts of southern Alaska and neighboring parts of Canada. Detailed geologic mapping of this island has led to a better understanding of the makeup of these belts and their role in the evolution of a large part of the North American Cordillera.

Reference: U.S. Geological Survey, 1952, Anchorage A-8 quadrangle, Alaska: U.S. Geol. Survey, Topog. Ser., scale $1: 63,360$.
Available from: Denver Distribution Section, U.S. Geological Survey, Federal Center, Denver, Colo. 80225; $\$ 0.75$.

A standard detailed togographic map at a scale of 1 inch equals 1 mile. In addition to the outlines of land and sea, the map shows streams, most of Anchorage, major roads, and the elevation of the land above sea level. Topographic maps are widely used by outdoor enthusiasts and planning engineers.

Reference: Schmoll, H. R., and Dobrovolny, Ernest, 1974, Foundation and excavation conditions map of Anchorage and vicinity, Alaska: U.S. Geol. Survey Misc. Geol. Inv. Map I-787-D, 1 sheet, scale 1:24,000.

Available from: Denver Distribution Section, U.S. Geological Survey, Federal Center, Denver, Colo. 80225; \$0.75.

A map showing the distribution of surficial deposits in the Anchorage area. It can be profitably be used by city planners in the development of zoning regulations, thus as suring not only future access to construction materials but adsquate foundations for buildings, as well.

Reference: Grantz, Arthur, McHendrie, A. G., Nilsen, T. H., Yorath, C. J., and Phillips, J. D., 1974, Digits l magetic tapes of single channel seismic reflection profiles on the continental shelf and slope between Bering Strait and Barrow, Alaska, and MacKenzie Bay, Canada: Natl. Tech. Inf. Service (U.S. Dept. Commerce) Magnetic Tape No. PB-232 344.

Available from: National Technical Information Service, U.S. Department of Commerce, Springfield, Va. $22161 ; \$ 4.00$.

Seismic reflection profiling is a technique us ad to determine the rocks and geologic structures that are beriec th the sea floor. The method is often the first stage in the search for offshore deposits of petroleum and gas.

Reference: Brew, D. A., 1974, Environmental impact analysis; the example of the proposed trans-Alaska pipeline: U.S. Geol. Survey Circ. 695, 16 p.

Available from: U.S. Geological Survey, Washington, D.C. 20244; copies are distributed free while the supply lasts.

An overview of the analysis that was invclved in the environmental impact statement for the oil pipeline from the scientific viewpoint. This summary can serve as a useful tool to scientists and planners who will be doing anal-'ses of environmental impacts for projects of any size.

Reference: MacKevett, E. M., Jr., and Plafker, George, 1974, The Border Ranges fault in south-central Alaska: U.S. Geol. Survey Jour. Research, v. 2, no. 3, p. 323-329.

Available from: Superintendent of Documents, Government Printing Office, Washington, D.C. 20402; $\$ 3.15$, single copy; $\$ 18.90$ per year.

A discussion of the Valdez and McCarthy quadrangles part of a major fault that can be traced for more than $1,000 \mathrm{~km}$ along the Pacific border of Alaska. The study is scholarly and illustrates recent advances in knowledge of the geologic structure and history in the rugged coastal mountains of southern Alaska.

In addition to its responsibility for obtaining and analyzing land and water resources data, the Geological Survey supervises the extraction of valuable mineral commodities from raany types of 


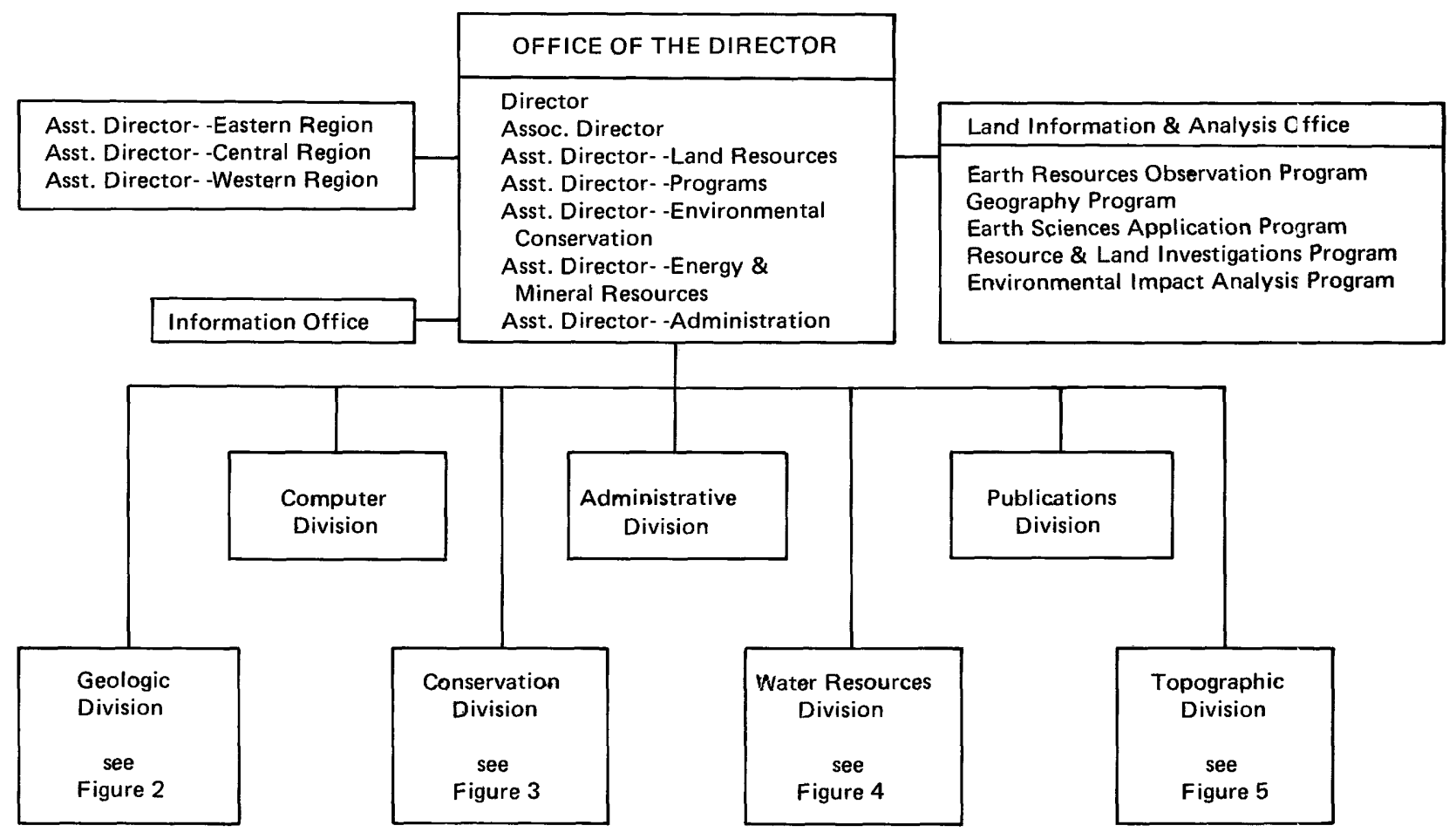

FIgURE 1.-Organization of the U.S. Geological Survey.

federal lands, including the offshore outer continental shelf.

The Alaskan activities of the Geological Survey are carried out through all of its four main operating divisions and by a number of interdivisional programs, committees, and working groups. These are briefly described in the following sections.

\section{ORGANIZATION OF THE U.S. GEOLOGICAL SURVEY}

The organization of the Geological Survey and its four main operating divisions is portrayed in figures 1 through 5 .

The main structure of the Geological Survey (fig. 1) consists of four operating divisions (Geologic, Conservation, Water Resources, and Topographic) and three support divisions (Computer, Administrative, and Publications). Headquarters for all divisions are in Reston, Va.

Investigations of the geology of the United States and certain other countries are mainly conducted in the Geologic Division under the direction of Richard P. Sheldon, Chief Geologist. The
Geologic Division (fig. 2) includes six operating offices (Mineral Resources, Environmental Geology, Geochemistry and Geophysics, Energy Resources and Marine Geology, Earthquake Studies, and International Geology) supported $k \times$ an Office of Scientific Publications. The headquarters of the offices are located in Reston, Va.

The Conservation Division supervis?s oil, gas, and other mineral extraction activities on certain federal lands. The regional responsibilities of the Division are vested in four operational offices: Eastern, Central, and Western Regions, and Gulf of Mexico Outer Continental Shelf. Tre Alaskan activities of the Conservation Division, which are especially emphasized in figure 3 , are supervised by the Western Region Office in Menlo Fark, Calif.

The organization of the Water Reso'urces Division of the Geological Survey is shown in figure 4 (with Alaskan activities emphasized). The main operating units are located under four regional subdivisions (Northeastern, Southeastern, Central, and Western) supported by Assirtant Chief Hydrologist Offices for Scientific Publications and Data Management, Operations, and Research and Technical Coordination. 


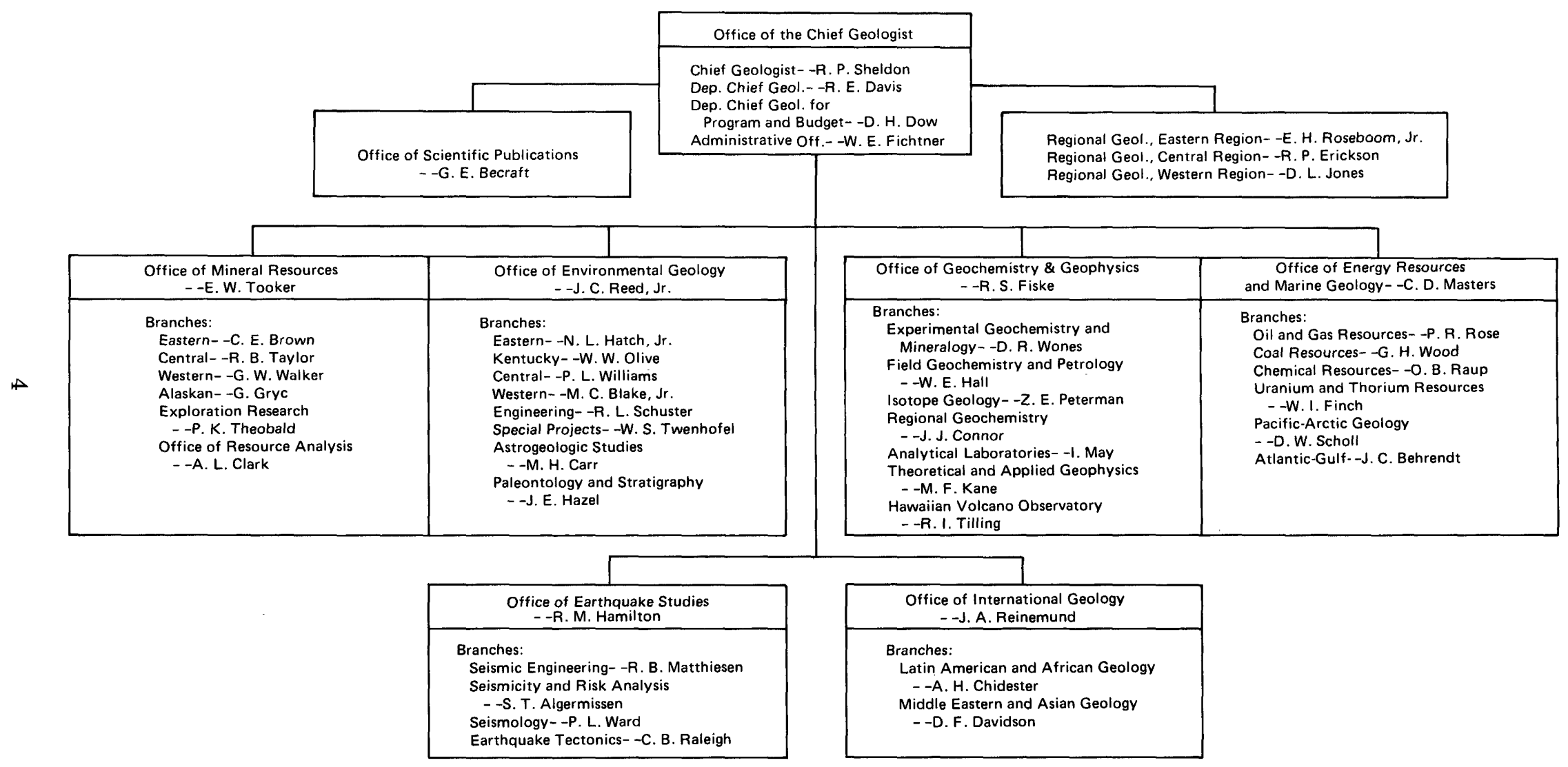

FIGURE 2.-Organization of the Geologic Division. 


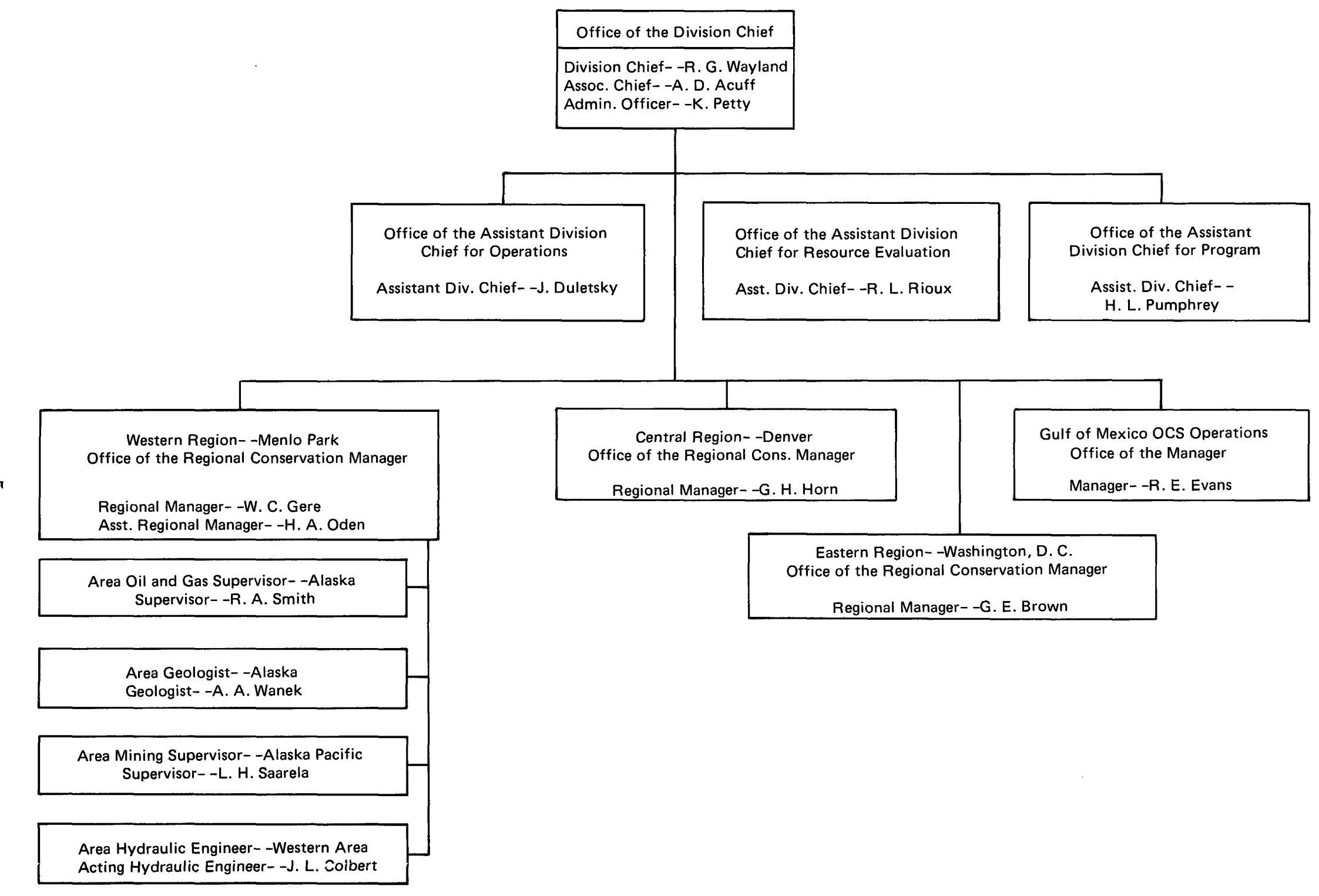

FIGURE 3.-Organization of the Conservation Division. 


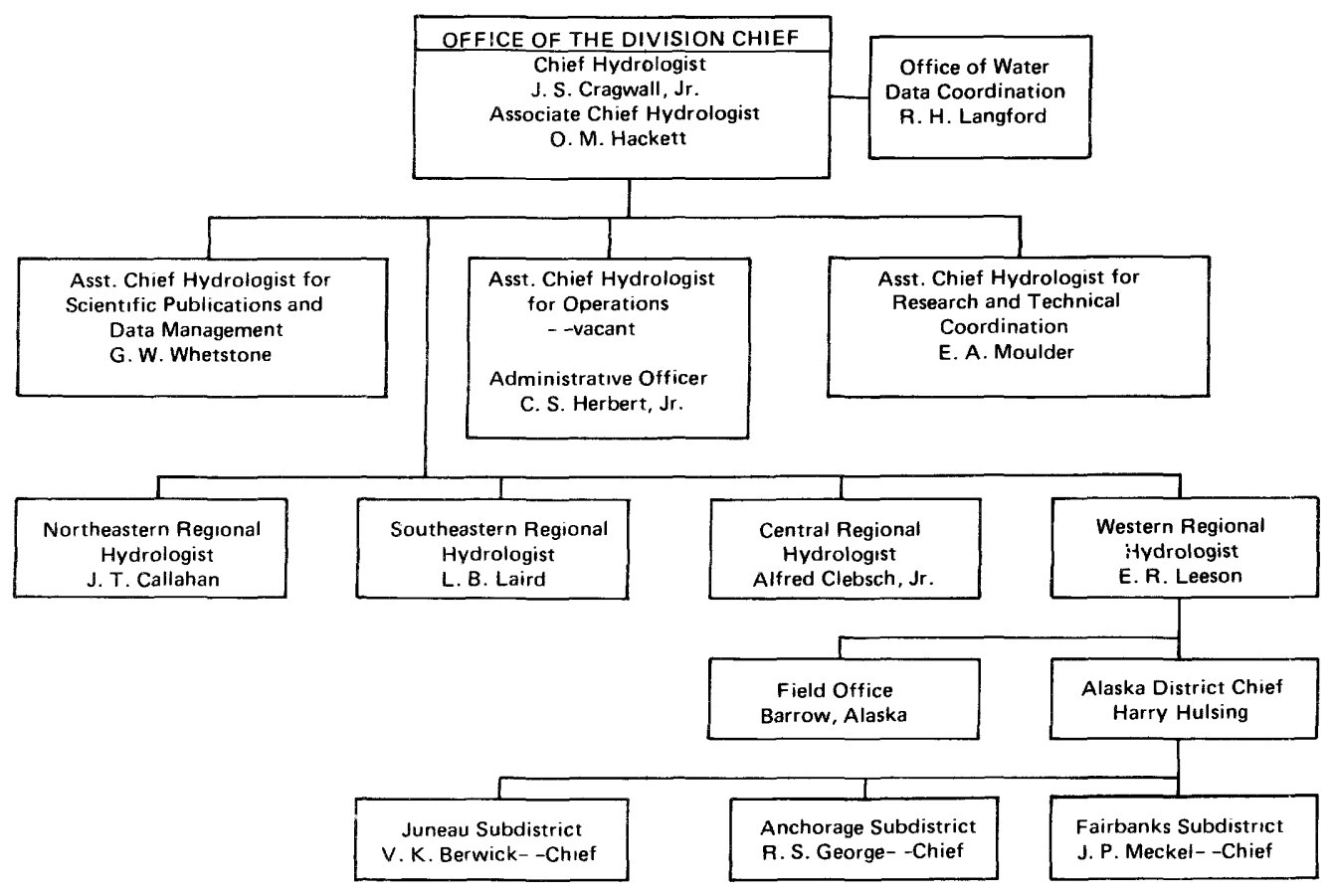

FiguRE 4.-Organization of the Water Resources Division.

The preparation of topographic and other special-purpose geographic maps is accomplished by the Topographic Division (fig. 5). The principal work responsibilities are met by the regional mapping centers (Eastern, Mid-continent, Rocky Mountain, and Western) under the supervision of the Chief of the Topographic Division.

\section{ORGANIZATIONAL SEGMENTS SERVING ALASKA}

All four operational Divisions of the Geological Survey-Conservation, Geologic, Topographic, and Water Resources-function in Alaska and are supported by the Administrative, Publications, and Computer Divisions, as well as other organizational entities of lower than Division rank.

\section{CONSERVATION DIVISION}

The Conservation Division examines and classifies federal lands as to their mineral character and waterpower and water-storage values; determines estimated resource values for onshore and offshore competitive lease sales; supervises exploration and development for leases on Federal, Indian, and certain Naval petroleum reserve land, and the offshore outer continental shelf; and maintains accounts and collects rentals and royalties from related mineral production.

Consistent with the national consern for environmental protection, the Division's regulations and procedures are subject to frequent reappraisal and revision in order to avoid or mitigate consequences that may result from pollution incidents, surface damage resulting from mining, geothermal, and petroleum operations, or other hazards that may be associated with mineral operations conducted under leases and prospecting permits.

These activities are under the general direction of Russell G. Wayland, Chief, Conservation Division, National Center, Mail Stop 600, 12201 Sunrise Valley Drive, Reston, Va. 22092. All Alaskan activities are supervised by W. C. Gore, Western Region Conservation Manager, 345 Middlefield Road, Menlo Park, Calif. 94025. The Office of the Alaska-Pacific Mining Supervisor, Le? H. Saarela, is also located at the Menlo Park address.

J. L. Colbert, the acting Hydraulic Engineer for the Western Region, is located at 830 N.E. Holladay, P.O. Box 3202, Portland, Ore. 97208, and the Alaska waterpower evaluation program is a function of that office. Both the office of the Alaska Area Geologist, Alexander A. Wanek, and that of the Alaska Area Oil and Gas Supervisor, Rodney A. Smith, are located at 800 A St., Anchorage, Alaska 99501. 


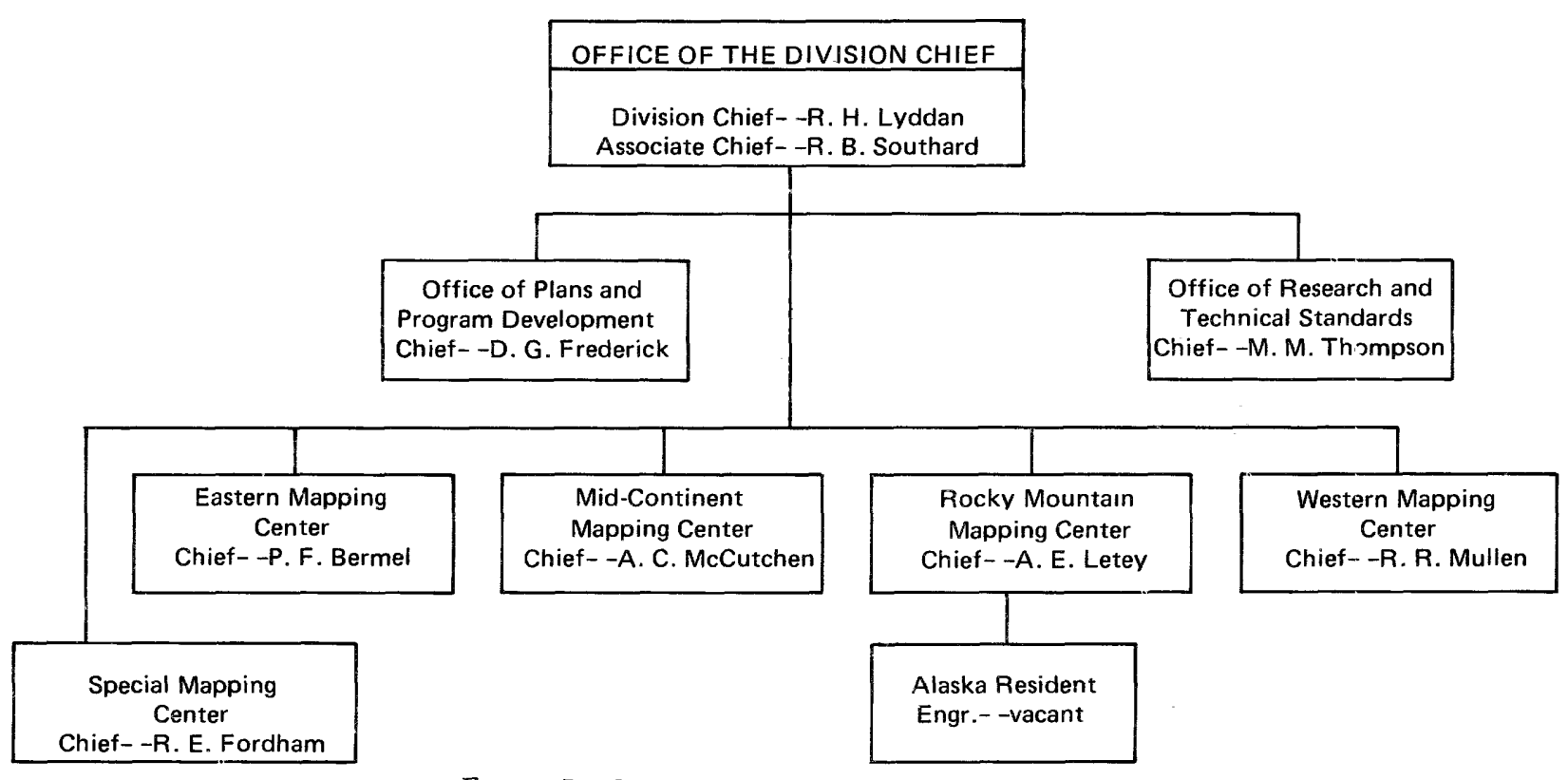

Figure 5.-Organization of the Topographic Division.

\section{GEOLOGIC DIVISION}

The current scientific investigations of the Geologic Division in Alaska include geologic mapping and mineral resource evaluation, principally at scales of $1: 250,000$ and 1:63,360; mineral district mapping and evaluation; mineral reconnaissance; geochemical studies and sampling, particularly related to mineral deposit studies; petroleum resource surveys; aeromagnetic and gravity surveys and interpretation; engineering geology studies in urban areas and transportation routes; earthquake studies; isotope age determination and interpretation; heat flow; and submarine sampling, subbottom profiling, and other geophysical studies of the ocean floor.

The Survey's program of geologic research is under the direction of Richard P. Sheldon, Chief Geologist. Activities in Alaska are the responsibility of several groups within the Geologic Division: The Branch of Alaskan Geology, the Office of Earthquake Studies, and the Office of Energy Resources and Marine Geology at the Pacific Coast Field Center, 345 Middlefield Road, Menlo Park, Calif. 94025; the Branches of Theoretical and Applied Geophysics, Exploration Research, Isotope Geology, and Engineering Geology at the Rocky Mountain Field Center, Denver, Colo. 80225; and the Branch of Paleontology and Stratigraphy at the National Center, Reston, Va. 22092. Several other branches of the Geologic Division provide services or conduct research in cooperation with these units. The Geologic Division maintains two offices in Alaska: the main one at 1209 Orca St., Anchorage, Alaska 99501 ([907] 272-8228), with Thomas P. Miller as the geologist in charge, and the other at the University of Alaska, ([907] 4797245) with Florence R. Weber in charge.

In its study of Alaskan geology, the Survey supports and cooperates with several universities and other public agencies, including the State of Alaska's Geological and Geophysical Survey.

\section{TOPOGRAPHIC DIVISION}

The Topographic Division's main task is the preparation of the National Topographic Map Series, which includes all of the quatrangle maps covering the 50 states of the nation. The topographic mapping program of the Goological Survey is under the direction of Robert $H$. Lyddan, Chief, Topographic Division. The $C$. fice of Plans and Program Development is responsible for initiating and controlling the work of the Division. The chief of this office is D. G. Frec'orick.

Mapping operations in Alaska are the responsibility of A. E. Letey, Chief, Rocky Mountain Mapping Center, who directs the operational functions of the mapping center, including all field and office operations. He may be consulted at the Federal Center, Denver, Colo. 80225 ([303] 234-3131, ext. 2351). 
WATER RESOURCES DIVISION

The Alaskan water resources program includes the collection, analysis, and interpretation of data on the availability and quality of surface and ground water and includes special studies and research that seek to evaluate and increase the effective use of water resources data in the State. This basic water data provides a broad base to support the proper management and protection of the State's water and related land resources.

The network of data collection sites maintained includes the following:

$\begin{array}{lrc}\text { Streamflow } & \begin{array}{c}\text { Daily } \\ \text { sites }\end{array} & \begin{array}{c}\text { Intermittent } \\ \text { or partial } \\ \text { record sites }\end{array} \\ \text { Sediment } & 108 & 82 \\ \text { Chemical } & 0 & 18 \\ \text { Biological } & 1 & 11 \\ \text { Temperature } & 11 & 4 \\ \text { Ground-water observation wells. } & 39 & 151 \\ \end{array}$

The Geological Survey's water resources investigations are under the direction of the Chief $\mathrm{Hy}$ drologist, Water Resources Division, Reston, Va. 22092. The investigations in the western United States, including Alaska, are under the jurisdiction of the Western Region office and are the responsibility of Elwood R. Leeson, Regional Hydrologist, 345 Middlefield Road, Menlo Park, Calif. 94025. The Anchorage District office is in the Skyline Bldg., 218 E St., Anchorage, Alaska 99501 ([907] 277-5526), under the supervision of Harry Hulsing, District Chief. This office is operated on a year-round basis and is responsible for planning and supervising Alaskan activities.

The field activities of the Alaska District are a function of the three Subdistrict offices: Anchorage, Fairbanks, and Juneau. The Anchorage Subdistrict office is responsible for operations in south-central and western Alaska and is under the supervision of Raymond S. George. It is located at 1209 Orca St., Anchorage, Alaska 99501 ([907] 279-1563). The Juneau Subdistrict office, which is responsible for operations in southeastern Alaska, is under the supervision of Vernon $\mathrm{K}$. Berwick and is located at 441 Federal Building, P. O. Box 1568, Juneau, Alaska 99802 ([907] 586-7217). The Fairbanks Subdistrict office is responsible for operations in northern Alaska and is under the supervision of James P. Meckel. It is located at 310 First Ave., Fairbanks, Alaska 99701 ([907] 452-1951, ext. 176).

A field office at Barrow, Alaska, has been estab- lished to support work being done on the Arctic Ice Dynamics Joint Experiment (AIDJEX). The address is U.S. Geological Survey, c/o AIDJEX Naval Arctic Research Laboratory, Barrow, Alaska 99723 ([907] 852-6588; commercial telephone is [907] 852-9245.

\section{PUBLICATIONS DIVISION}

The Publications Division edits scientific and technical manuscripts; reproduces top graphic, geologic, and other maps; prepares exhibits and visual aids; disseminates general Survey program and publications information and distributes maps to the public. These activities are under the direction of Harry D. Wilson, Jr., Chief, Publications Division, National Center, Reston, Va. 22092.

The Division maintains two offices in Alaska for the customers' convenience in obtaining maps, book reports, and other material prepared by the U.S. Geological Survey.

The Alaska Distribution Section at 310 First Ave., Fairbanks, Alaska 99701 ([907] 452-1951, ext. 174) is supervised by Natalie A. Cornforth under the direction of the Publications Division, Western Region, Menlo Park, Calif. It distributes maps and map-related publications by mail and over the counter to the public, to $25 \mathrm{ccmmercial}$ dealers in Alaska, and to Federal and State agencies. A schedule of map prices and discounts is available on request. During calendar year 1974, the Alaska Distribution Section dispensed more than 138,000 items.

A Public Inquiries Office, at 108 Skyline Building, 508 Second Ave., Anchorage, Alaska 99501 ([907] 277-0577), is supervised by Margaret I. Erwin under the direction of the Office of Public Inquiries, Publications Division, National Center, Reston, Va. It maintains a stock of Alaska topographic and geologic maps for over-tl e-counter sale, and, as an agent of the Superintendent of Documents, sells Geological Survey book reports on Alaska. It serves as a public contac ${ }^{+}$point for Survey activities in the State and has a complete library of all Survey publications. The office is a depository for Alaska open-file reports and maintains a browse file containing microfilms of LANDSAT (satellite) images. During tho calendar year 1974, the Anchorage office hac' approximately 26,000 public contacts. 


\section{ADMINISTRATIVE DIVISION}

The Alaska Field Office of the Administrative Division is located at 204 Skyline Building, $218 \mathrm{E}$ Street, Anchorage, Alaska 99501. The phone number for this office is [907] 277-0569. The office is supervised by Betty J. McIntire and provides service and supply support to U.S. Geological Survey offices and personnel in Alaska. For this reason, it is important that itineraries of all transients to Alaska are supplied to the Alaska Field Office to facilitate forwarding of mail and messages.

Arrangements for U.S. Geological Survey personnel to stay at the Alyeska Pipeline Service Company camps, and reservations for transportation to the camps, are made by Mrs. McIntire in Anchorage. Notice in advance is necessary.

The Anchorage Warehouse is under the supervision of Clarence (Buck) Buchanan and is located about 5 miles east of downtown Anchorage, just inside the boundary of Elmendorf Air Force Base ([907] 753-2119). Field equipment and samples may be shipped to the warehouse for storage. The address is: 5500 Oilwell Road, Elmendorf Air Force Base, Anchorage, Alaska 99506. The warehouse for the Fairbanks area is located at Ft. Wainwright but will be staffed only if warranted by the level of field activity. The telephone number at Ft. Wainwright is: [907] 353-3139.

\section{ALASKA SURVEY COMMITTEE}

Discussion and coordination of Alaska activities are provided by the Alaska Survey Committee, a forum in which each of the Divisions of the Geological Survey operating in Alaska is represented. Florence R. Weber, Geologic Division, chairs the group for 1975; other members are Harry Hulsing, Water Resources; Alexander A. Wanek, Conservation; Thomas J. O'Brien, Topographic; Margaret I. Erwin, Publications; and Betty J. McIntire, Administrative.

\section{EMERGENCY SEARCH AND RESCUE}

To initiate search and rescue in cases of emergency, contact the Air Rescue Coordination Center in Anchorage at any time during the day or night. Communications can be made directly to the center, telephone: [907] 277-2131, 752-1106, 7520227, through the Alaska Field Office, either tele- phone or radio (see section on Radis Network), nearest FAA Flight Service Station, military installation, or State Troopers. To the extent possible, specify location and nature of emergency, time of the accident, number of people involved, and the nature of possible injuries.

For the purpose of notifying headquarters and family of any emergency, please contact Betty McIntire (work: [907] 277-0569, home: [907] 2725398) or Buck Buchanan (work: [907] 277-0569, home: [907] 333-9445) as soon as possible.

\section{RADIO NETWORK}

Radio Officer for Alaska is Florence R. Weber, Geologic Divison, College, Alaska 99701 ([907] 479-7245). Two frequencies, $5380(5381.5) \mathrm{kHz}$ and $3211.0(3212.5) \mathrm{kHz}$ (both upper SSB) are the official frequencies for U.S.G.S. personnel.

For the 1975 field season, two base stations will be established through commercial radio service facilities. Alaska Public Fixed $5167.5(5168.9) \mathrm{kHz}$ will be monitored from 6:00 a.m. through 9:00 p.m. daily in Anchorage and from 7:00 a.m. through 10:00 p.m. in Fairbanks. Only emergency calls will be accepted outside of these hours. 3211 (3212.5) $\mathrm{kHz}$ will be monitored in Anchorage and possibly in Fairbanks. Calls of commercial stations are WKD22 in Anchorage and KGA85 "Broadmoor" in Fairbanks.

\section{EROS PROGRAM}

The EROS (Earth Resources Observation Systems) Program was established by the U.S. Department of the Interior in 1966 to as rist in realizing the practical benefits in earth resource and environment inventory and monitoring that can be obtained by use of photography and other remote sensing data acquired by aircraft and space craft, particularly the Earth Resources Technology Satellite (ERTS), now renamed LANDSAT. The EROS Program is managed by the U.S. Geological Survey and directed by John N. DeNoyer, with headquarters at EROS Program, U.S. Geological Survey, 1925 Isaac Newton Square East, Reston, Va. 22090 ([703] 860-7881 to $-78 \varepsilon 5$ ). The representative of EROS Program for Alaska and the Pacific States is Ernest H. Lathram, EROS Applications Assistance Facility, U.S. Geological Survey, 345 Middlefield Road, Menlo Park, Calif. 94025 ([415] 323-8111, ext. 2727). 
EROS Data Center, Sioux Falls, S. Dak. 57198 ([605] 594-6511), is responsible for distributing LANDSAT (formerly ERTS) imagery and other remote sensing data to users throughout the world, as well as developing techniques of application of remote sensing to various resource problems and assisting users in employing these techniques. A large staff of specialists in a variety of disciplines is available to assist in the development of new applications. Information requests ranging from specific problems to future training opportunities may be directed to the Applications Assistance Branch of the Data Center.

In November 1974, an EROS Applications Assistance Facility was established in Alaska to improve the availability of technical assistance to Alaskan users. This facility, located at the Geophysical Institute, University of Alaska, College, Alaska 99701 ([907] 479-7487), was initially established by NASA to provide assistance to Alaskan ERTS-1 investigators, and is now being operated under contract to the EROS Program to provide assistance to the entire Alaskan user community. The facility is supervised by Albert $\mathrm{E}$. Belon, under the general direction of John M. Miller. Both standard and sophisticated interpretation equipment, including a color additive viewer and minicomputer enhancer are available. In addition, files of selected LANDSAT imagery, NASA and other aerial photography, and other remote sensing data on various parts of Alaska are maintained.

The Applications Assistance Facility has arranged for William Stringer of the University of Alaska to spend 1 week each month at the Arctic Environmental Information and Data Center, 707 A St., Anchorage, Alaska 99501 ([907] 279-4523), to answer questions and provide more direct assistance to Anchorage area users.

Alaskan LANDSAT imagery is also available for inspection at the Public Inquiries Office, U.S. Geological Survey, Rm. 102, 800 A St., Anchorage, Alaska 99501.

\section{ALASKAN PROJECTS OF THE U.S. GEOLOGICAL SURVEY}

Much of the work of the Geological Survey is organized and accomplished by projects in which the investigations of one or more scientists, engineers, and technicians are directed by a project chief. Some of the projects are statewide in scope, but most focus on one or more aspects cf topography, geology, or hydrology in particular parts of Alaska. Summarized in this section are the statewide and regional Survey projects planned for the field season of 1975 . Summarized in a subsequent section are the projects undertaken in cooperation with various agencies of the State of Alaska.

\section{STATEWIDE PROJECTS}

Project: Mineral resources of Alaska.

Region: Statewide.

Organizational designation: Geologic I:vision, Office of Mineral Resources, Branch of Alaskan Geology.

Project chief: Edward H. Cobb, U.S. Geological Survey, 345 Middlefield Road, Menlo Park, Calif. 94025; [415] 323-8111, ext. 2213.

Project plans: Office studies of mineral occurrence data will be pursued and metallic mineral commodity maps kept current, enabling p'rblished commodity maps to be brought up to date and republished (if additions would be significant) when present stocks become exhausted. Lists of references to recent Federal and State re norts on the geology and mineral resources of Alaska, indexed by topographic mapping quadrangles (scale 1:250,000), will be issued annually. These data are also being entered in a computerized storage and retrieval bank.

Project: Identification of geostructures of continental crust from space craft imagery.

Region: Statewide.

Organizational designation: EROS Program and Geologic Division, Office of Mineral Resources, Branch of Alaskan Geology.

Project chief: Ernest H. Lathram, U.S. Geological Survey, 345 Middlefield Road, Menlo Park, Calif. 94025; [415] 323-8111, ext. 2231 and 2727.

Project plans: The purpose of this project is to apply LANDSAT, NOAA, and Nimbus satellite imagery in identifying geological structures of regional extent in Alaska and interpreting their significance as guides to the emplacement of mineral and mineral fuel resources, as guides to development of exploration rationales and as controls to theories of the formation ard deformation of the continental crust of Alaska. Results of this project are also contributions to the 


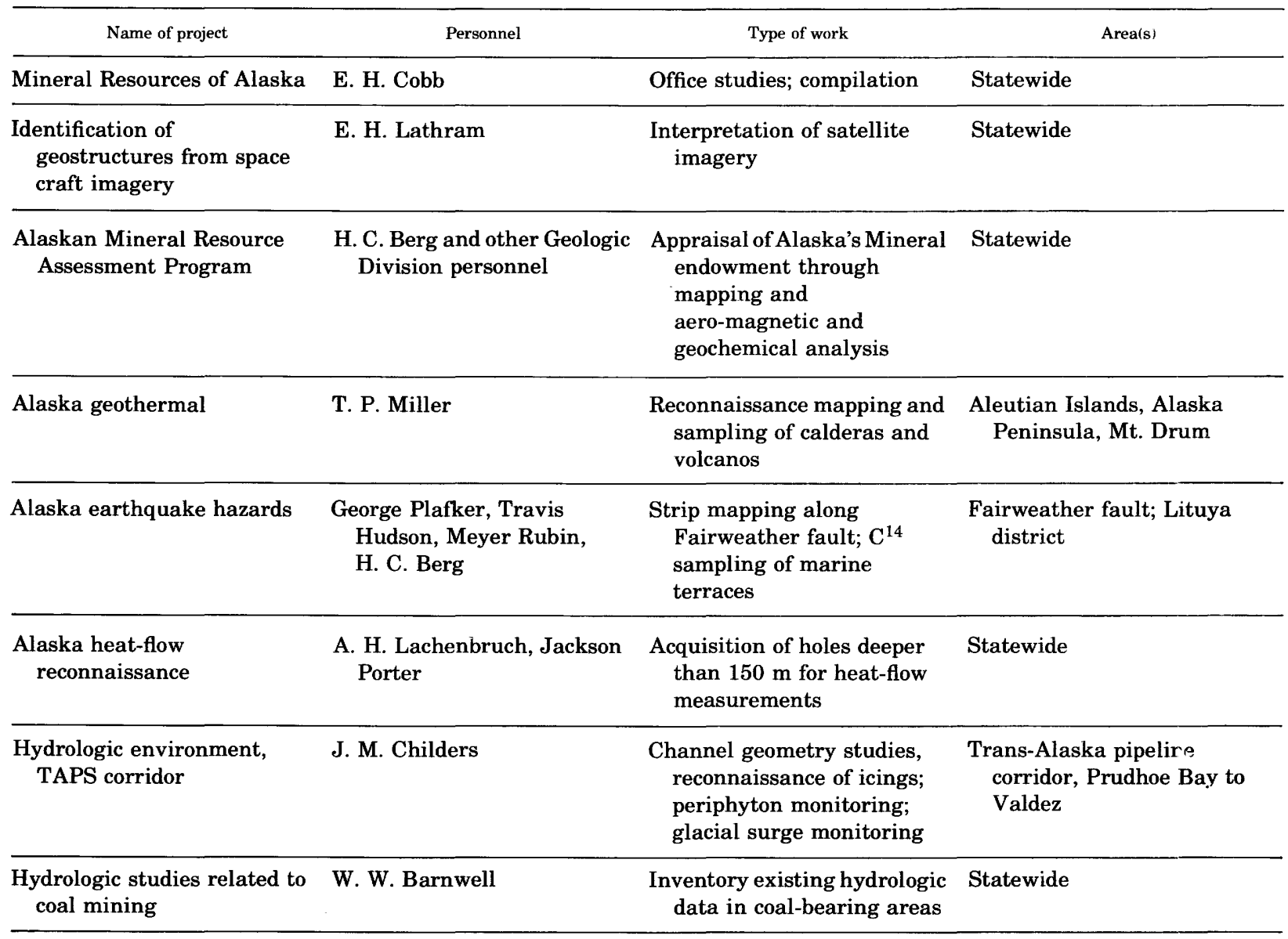

Joint US/USSR Working Group on the Natural Environment.

Project: Alaskan Mineral Resource Assessment Program (PAMRAP and AMRAP).

Region and map keys: Statewide $(6,8,9,15,17$, $18,22,24,31$ ).

Organizational designation: Geologic Division, Office of Mineral Resources, Branch of Alaskan Geology.

Program manager: Henry C. Berg, U.S. Geological Survey, 345 Middlefield Road, Menlo Park, Calif. 94025; [415] 323-8111, ext. 2266.

Project plans: The Alaskan Mineral Resource Assessment Program, authorized by Congress to begin on July 1, 1974, calls for an accurate appraisal of Alaska's mineral endowment within 10 years. A rapid assessment of this vast and potentially mineral-rich region is required both to plan a viable long-range national minerals policy and to assist in decisions on Alaskan land use and development over the next decade.

Because mineral appraisals of such remote and little-known regions as Alaska are still largely experimental, the program was begun with an interdisciplinary (geochemistry, geophysics, telegeology, regional mapping) experiment to develop specific guidelines, techniques, and products as a model for a statewide mineral inventory. Called PAMRAP (Prototype Alaskan Mineral Resource Assessment Program), this two-year program of reconnaissance geologic mapping and other field and laboratory studies will also provide greatly improved mineral resource information for selected prototype study areas.

The four 1:250,000 quadrangles selected for PAMRAP are: Talkeetna, Tanacross, N'abesna, and McCarthy. Each of these is managed by a "team-leader": B. Reed, H. Foster, D. Richter, and E. MacKevett, Jr., respectively. Tore are ten additional quadrangles currently scheduled for appraisal under AMRAP: Big Délta, 
Seward-Blying Sound, Chandalar, Philip Smith Mountains, Goodnews-Hagemeister Island, Ketchikan-Prince Rupert, and Talkeetna Mountains. The team-leaders for these quads are H. Foster, R. Tysdal, W. Brosgé, H. Reiser, W. Coonrad, H. Berg, and B. Csejtey. More detailed project plans may be found in the following section under the individual quadrangles.

The Branch of Exploration Research (BOER) will conduct regional geochemical surveys of the Chandalar quadrangle, and parts of the Talkeetna, Talkeetna Mountains, Goodnews, Big Delta, and Seward quadrangles this summer. These surveys are designed to outline and aid in the classification of areas of mineralized rock for their mineral resource potential. The surveys will be of a reconnaissance nature except in those areas where more specialized geochemical studies are indicated. A special laboratory will be established in Anchorage for the summer to analyze the PAMRAP-AMRAP samples.

Personnel from the Branch of Theoretical and Applied Geophysics will participate in ground geophysical studies in a number of the PAMRAP-AMRAP quadrangles, including Talkeetna Mountains, Goodnews, Chandalar, Philip Smith, Seward, and Blying Sound. Much of the work will consist of gravity surveys but some ground magnetic surveys and sample collection will be conducted in areas of special interest.

Project: Alaska geothermal.

Region and map key: Statewide (14).

Organizational designation: Geologic Division, Office of Mineral Resources, Branch of Alaskan Geology.

Project chief: Thomas P. Miller, U.S. Geological Survey, 1209 Orca St., Anchorage, Alaska 99501; [907] 272-8228.

Project plans: Approximately 2 weeks will be spent in the eastern Aleutian Islands conducting helicopter-supported geologic mapping and sampling of Quaternary calderas, including Fisher, Akutan, Makushin, and Okmok. One week will be spent enroute back to Anchorage completing reconnaissance mapping of calderas on the Alaskan Peninsula and sampling of the precaldera volcanoes for $\mathrm{K} / \mathrm{Ar}$ age dating. Reconnaissance studies in the general area of Mount Spurr will be carried out from Anchorage for about a week.
Following these reconnaissanc? studies, a gravity survey will begin in the western Wrangell Mountains, centering around Mount Drum; a complementary aeromagnetic survey may also be conducted in this region.

Project: Alaska earthquake hazards

Region and map key: Statewide (27).

Organizational designation: Geologic Division, Office of Mineral Resources, Branch of Alaskan Geology.

Project chief: George Plafker, U.S. Geological Survey, 345 Middlefield Road, Menlo Park, Calif. 94025; [415] 323-8111, ext. 2201.

Project plans: The overall objective of this project is to study and evaluate risk in Alaska from tectonic displacement, seismic shaking, and secondary geologic effects. A more general goal is to gain insight into tectonic processes within the seismically active zones of Alaska, with special emphasis on south-central Alaska.

Plans for 1975 involve roughly 15 days of helicopter-supported fieldwork during June in the Lituya district and on Chichagof and Baranof Islands. From June 1 through 21, Plafker, Travis Hudson, and Meyer Rubin will be based on the R/V Don J. Miller in Lituya Bay during which time they plan to carry out detailed strip mapping along the southern segment of the Fairweather fault and will map and sample (for $\mathrm{C}^{14}$ dating) the marine terraces along the Lituya district coast. From June 23 through 30, Plafker, Hudson, and Henry Berg will be based at Sitka while they make a reconnaissance study of the major tectonic features on Chichagof and Baranof Islands.

Project: Alaska heat-flow reconnaisrance.

Region: Statewide.

Organizational designation: Geologic Division, Office of Earthquake Studies, Earthquake Tectonics Branch.

Project chief: Arthur H. Lachenbruch, U.S. Geological Survey, 345 Middlefield Road, Menlo Park, Calif. 94025; [415] 323-8111, ext. 2272. Project representative in Anchorc ge, from approximately June 15: Jackson R. Porter, c/o U.S. Geological Survey, 1209 Orca Street, Anchorage, Alaska 99501; [907] 272-8228.

Project plans: Continued acquisition of holes (deeper than $150 \mathrm{~m}$ ) drilled by mineral and oil 
exploration companies, for temperature measurements. Subject to the approval of the operators, and on a noninterference basis, plastic pipe ( $3 / 4$ inch i.d.) will be taken into the drilling camps for insertion into completed holes to preserve them for later temperature measurements. We will concentrate on extending our coverage of heat flow in intrusive and metamorphic terrains, as part of continuing studies relating to the energetics of earthquakes and to geothermal resource reconnaissance. Persons who know of plans or who have plans to drill to depths greater than $150 \mathrm{~m}$ (500 feet) should contact either the project chief or, after June 15, the project representative in Anchorage. Any information of this type would be greatly appreciated.

Project: Hydrologic environment of the transAlaska pipeline system (TAPS), Alaska.

Region: Statewide, transportation corridor, Arctic Ocean (Prudhoe Bay) to Pacific Ocean (Valdez).

Organizational designation: Water Resources Division, Alaska District Office.

Project chief: J. M. Childers, U.S. Geological Survey, 218 E Street, Anchorage, Alaska 99501; [907] 277-5526.

Project plans: The objective of this project is to assess the hydrologic impact of the trans-Alaska pipeline system. Channel geometry studies will be extended to small steams in order to establish flood risk zones and evaluate erosion potential; reconnaissance of icings along the pipeline route will be continued. ERTS imagery and other remote sensing will be used to inventory large icings. A periphyton (micro-organisms) monitoring system in the northern half of the pipeline route will be established. Monitoring of glacier dammed lakes near the pipeline route and research into the surge mechanics of Black Rapids Glacier will be continued. Aerial photography will be continued in order to monitor glacial streams and icing changes along the pipeline corridor.

Project: Hydrologic studies related to future mining of coal in Alaska.

Region: Statewide.

Organizational designation: Water Resources Division, Alaska District Office.
Project chief: W. W. Barnwell, U.S. Geological Survey, 218 E Street, Anchorage, Alaska 99501; [907] 277-5526.

Project plans: The purpose of this project is to inventory existing data relating to hydrologic conditions in coal-bearing areas and make recommendations for the future collection of hydrologic data in developing the reas.

\section{PROJECTS WITH REGIONAL EMPHASIS}

The major part of the Geological Survey's Alaskan program consists of projects of less than statewide scope. In this summary of 1975 regional project plans, data on the location, $\mathbf{s}^{+}$affing, and plans are presented. The location of each project is also shown by number on the accompanying map (fig. 6), as is the location of the several statewide projects which have a regional focus for the summer's activities.

Many projects are intensive investigations that require several years to complete. As with most technical studies, final formulation $\varepsilon$ nd publication of results are accomplished at the end of the investigation. For some projects, however, interim results and findings are compiled and presented in the section of this report on "S.ummary of Important Results, 1974." Interim accounts of the continuing hydrological investigations are prepared and separately published by the Water Resources Division. Inquiries on the status of the various project should be directed to the project chief at the address listed in the project summary.

\section{NORTHERN ALASKA}

Project: Beaufort-Chukchi Sea continental shelf. Region: Northern Alaska.

Organizational designation: Geolog: Division, Office of Energy Resources, and Marine Geology, Pacific-Arctic Branch.

Project chief: Arthur Grantz, U.S. Geological Survey, 345 Middlefield Road, Menlo Park, Calif. 94025; [415] 323-8111, ext. 2259.

Project plans: No fieldwork is planned on this project during 1975.

Project: Arctic coastal and shelf processes and the environment of the Beaufort Sea.

Region and map key: Northern Alaska (1). 


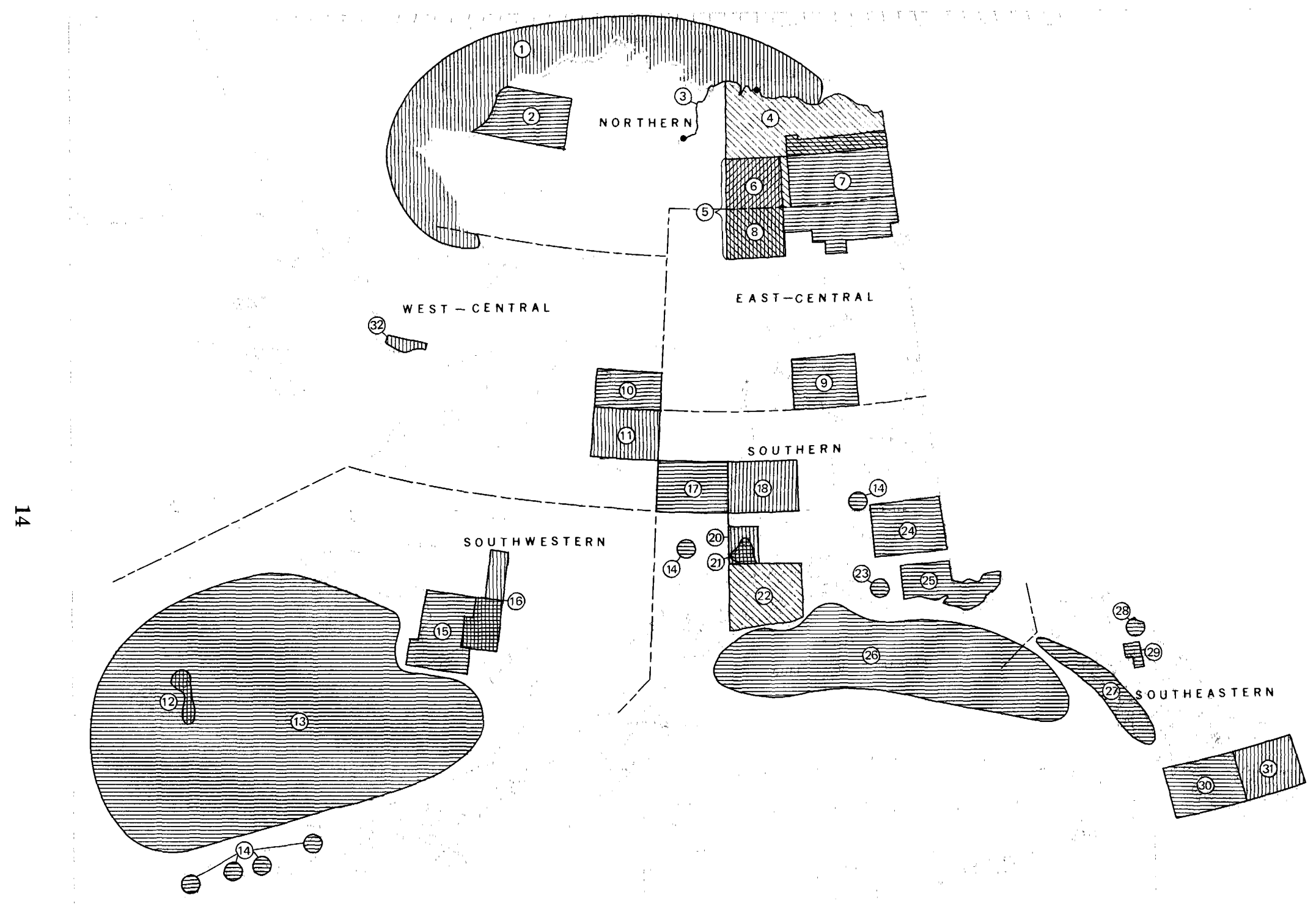

FIGURE 6.-Locations of 1975 field projects of the U.S. Geological Survey. 
Organizational designation: Geologic Division, Office of Marine Geology, Pacific-Arctic Branch.

Project chiefs: Erk Reimnitz, P. W. Barnes, U.S. Geological Survey, 345 Middlefield Road, Menlo Park, Calif. 94025; [415] 323-8111, ext. 2695 and 2114 respectively.

Project plans: Our operations in the next 2 years will focus on the shelf region from the winter shear zone (at 10-30 m of water depth) shoreward to the coast. To accomplish these studies the Geological Survey is constructing a shallow draft research vessel to replace the $\mathrm{R} / \mathrm{V}$ Loon, which was used in the Beaufort Sea during 1971, 1972, and 1973. This new vessel, the R/V Karluk is especially adapted for independent operation on the inner shelf.

The Karluk will be barged to Kotzebue by mid-July 1975 and commence work on the inner shelf, following the retreating ice around Barrow, thence work eastward as far as Flaxman Island.

Equipment operated routinely aboard the vessel includes bottom sampling and coring gear, water salinity-, temperature-, and turbidity sensors, current meters, fathometers, a high resolution seismic system, side scan sonar, and underwater television. This equipment will be used in a reconnaissance survey between Kotzebue and Harrison Bay, broadening the data base of our existing studies in the Prudhoe Bay area and on the outer shelf. Some of the problems we will be studying include (1) distribution, rates, and intensity of ice gouging, (2) potential areas for offshore gravel resources, (3) inner shelf oceanography as it relates to the sedimentary environment, (4) Pleistocene stratigraphy and recent geologic history, and (5) inner shelf sediment transport regime of icerafting, river effluents, and sediment resuspension by ice and benthos.

Between Barrow and Prudhoe Bay, a seismic refraction system will be used in cooperation with the Institute of Geophysics of the University of Alaska, to study offshore permafrost on the inner shelf.

Special problems which have arisen from our earlier studies between Harrison Bay and Flaxman Island will be worked on during the later part of the season. These will involve (1) implanting current meters for observations during freezeup and throughout the ice covered period, (2) repetitive sonar and fathometer surveys, (3) diving (SCUBA) observations and bottom photography, (4) measurements of sediment thicknesses within ice gouges, $(5)$ coring in sands, silts, and gravels, and (6) measurement of river delta sediments and sedimentary processes.

Project: Kokolik-Utokok River Coal Investigations.

Region and map key: Northern Alaska, Point Lay and Utokok River Quadrangles (2).

Organizational designation: Conservation Division, Office of the Area Geologist, Alaska Area. Project chief: J. E. Callahan, P. O. Box 259, Anchorage, Alaska 99510; [907] 277-0570.

Project plans: To prepare for the eventuality that oil and gas in Naval Petroleum Reserve No. 4 will be leased and managed by the Interior Department, it is proposed to extend investigations in the Cretaceous coals of Ncrthwestern Alaska into the western part of the Reserve from previously mapped areas in the Kukpowruk River-Cape Beaufort area. The investigation will include surface geologic mapping between Kukpowruk and Kokolik Rivers and along the Kokolik, with a limited amount of shallow augering in an attempt to stratigraphically project significant coal beds into upland areas away from outcrops along the major streams.

Project: Regional Petroleum Geoloxy, Alaska North Slope.

Region: Northern Alaska, north flank of the Brooks Range to the Arctic Ocean.

Organizational designation: Geologis Division, Office of Energy Resources and Marine Geology, Branch of Oil and Gas Resources.

Project chief: Robert D. Carter and Irvin L. Tailleur, U.S. Geological Survey, 345 Middlefield Road, Menlo Park, Calif. §4025; [415] 323-8111, ext. 2116 and 2254 , respoctively.

Project plans: Reconnaissance geologic investigations and mapping with helicopter support along the north flank of the Brooks Range. Objective is to study Cretaceous and Mississippian facies to determine depositional environments, lateral relationships, and correlations; to gather data on structural relationships, especially thrust sequences; and to collect samples for geochemical and paleontologic studies. Petrographic studies of the Lisburne group directed toward evaluation and documentation of the reservoir 


\begin{tabular}{|c|c|c|c|}
\hline Name of project & Personnel & Type of work & Area(s) \\
\hline $\begin{array}{l}\text { Kokolik-Utokok River coal } \\
\text { investigations }\end{array}$ & J. E. Callahan & $\begin{array}{l}\text { Surface geologic mapping; } \\
\text { shallow augering }\end{array}$ & $\begin{array}{l}\text { NPR-4 between Kukpowruk } \\
\text { and Kokolik Rivers }\end{array}$ \\
\hline $\begin{array}{l}\text { Regional petroleum geology, } \\
\text { North Slope }\end{array}$ & $\begin{array}{l}\text { R. D. Carter, I. L. Tailleur, } \\
\text { K. Bird, B. Kososki, } \\
\text { C. Mayfield, C. G. Mull }\end{array}$ & $\begin{array}{r}\text { Geologic mapping and } \\
\text { depositional studies }\end{array}$ & $\begin{array}{l}\text { Northern flank of Brooks } \\
\text { Range }\end{array}$ \\
\hline Arctic Environmental studies & O. J. Ferrians, Jr. & $\begin{array}{l}\text { Engineering-geologic } \\
\text { mapping }\end{array}$ & $\begin{array}{l}\text { Northern Alaska, Arctic } \\
\text { Coastal Plain }\end{array}$ \\
\hline $\begin{array}{l}\text { Quaternary geology, central } \\
\text { Brooks Range }\end{array}$ & $\begin{array}{c}\text { Thomas Hamilton, } \\
\text { Robert Thorson }\end{array}$ & $\begin{array}{l}\text { Reconnaissance surficial } \\
\text { mapping, stratigraphic } \\
\text { studies }\end{array}$ & $\begin{array}{l}\text { Philip Smith Mourtains and } \\
\text { Chandalar quad angles }\end{array}$ \\
\hline Philip Smith Mts. (AMRAP) & $\begin{array}{l}\text { Hillard N. Reiser, William P. } \\
\text { Brosgé, R. L. Detterman, } \\
\text { J. T. Dutro, Jr., David } \\
\text { Orchard }\end{array}$ & $\begin{array}{l}\text { Geologic mapping, } \\
\text { biostratigraphic studies }\end{array}$ & Philip Smith quad rangle \\
\hline
\end{tabular}

potential. A paleomagnetic study and gravity survey are contemplated if equipment and personnel become available.

Subsurface studies beginning in the Prudhoe Bay area integrating well log and geophysical data. A bibliography of geological literature on the North Slope to be prepared and published as an open-file report.

Project personnel include K. Bird, B. Kososki, C. Mayfield, and C. G. Mull.

Project: Western Alaska Cenozoic Gubik Formation Study.

Region and map key: Northern Alaska; parts of Umiat, Harrison Bay, and Beechey Point quadrangles (3).

Organizational designation: Geologic Division, Office of Mineral Resources, Branch of Alaskan Geology.
Project chief: D. M. Hopkins (pro tem), U.S. Geological Survey, 345 Middlefield Road, Menlo Park, Calif. 94025; [415] 323-8111, ext. 2659. Project plans: Projected field plans call for a party of three, under the leadership of Louis ("Dave") Carter, to enter the Colville River at T.Jmiat on a rubber-raft expedition downriver to the coast, then eastward along the coast to Prudhoe Bay. Focus will be on detailed stratigraphic analysis of the exposures of the Gubik Formation, to determine the maximum extent of the marine transgressions represented by the formation, and sampling for foraminifera, ostr coda, and mollusks at selected localities. Hones are to expand the known fauna, and possibly identify any distinctive faunal zonation that may be present. The project is being oporated in cooperation with the Arctic nearshor? project of Erk Reimnitz and Peter Barnes, to provide 


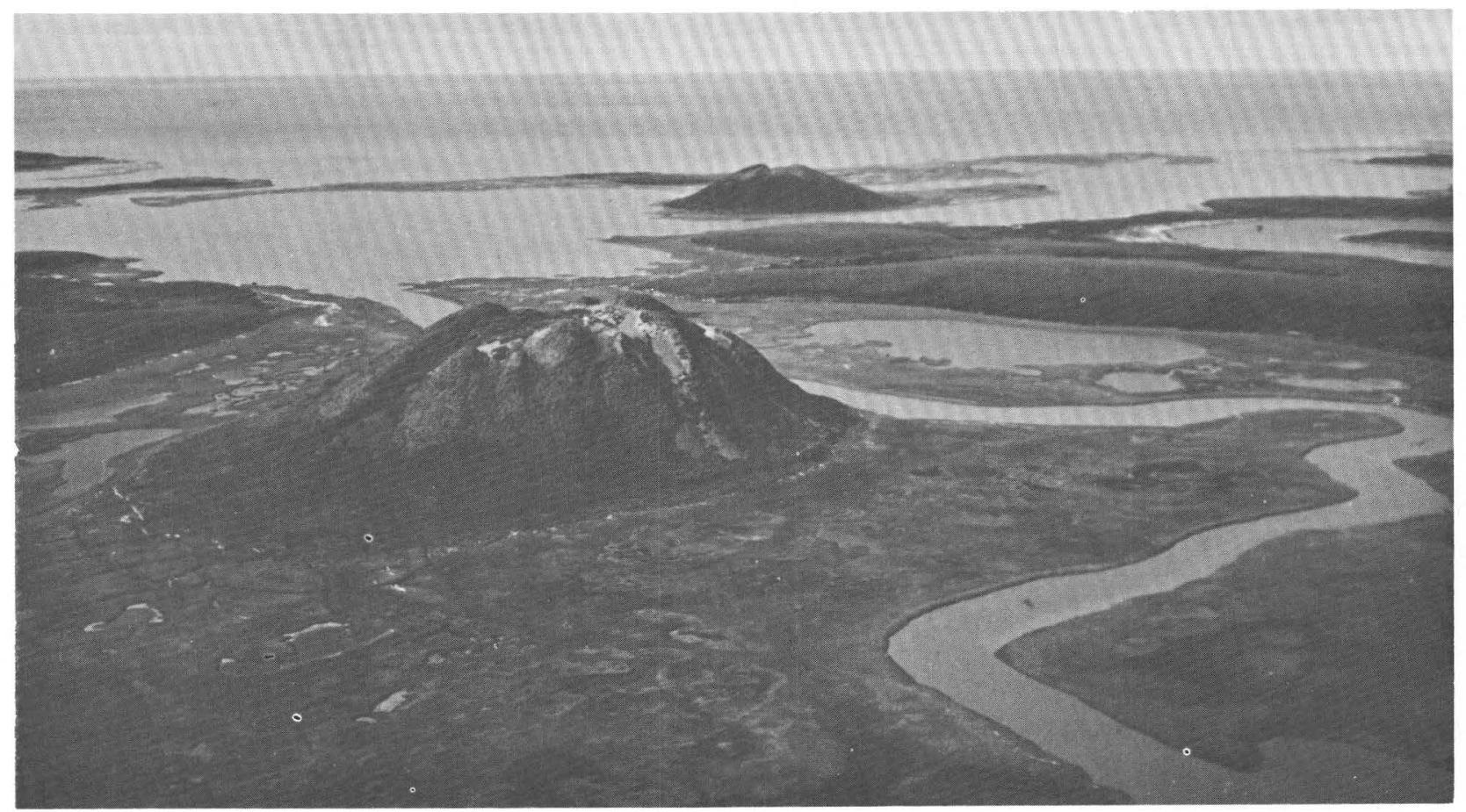

FIGURE 7.-A well-developed pingo (ice-cored hill) near Inuvik, Canada. Pingos occur frequently in the continuous permafrost zone of Alaska.

knowledge of the onshore stratigraphy to assist in interpretation of their seismic records, as well as to expand knowledge of the onshore geclogy and of sea level fluctuations along the Arctic coast. Bob Nelson, Roger Hartz, and Dave Carter expect to spend some 6 to 7 weeks working the river and coastal bluffs along the 200-mile route.

Project: Arctic Environmental Studies.

Region and map key: Northern Alaska, Arctic Coastal Plain-Prudhoe Bay to Alaska-Yukon border; parts of Beechey Point, Sagavanirktok, Flaxman Island, Mt. Michelson, Barter Island, and Demarcation Point quadrangles (4).

Organizational designation: Geologic Division, Office of Mineral Resources, Branch of Alaskan Geology.

Project chief: Oscar J. Ferrians, Jr., U.S. Geological Survey, 345 Middlefield Road, Menlo Park, Calif. 94025; [415] 323-8111, ext. 2247.

Project plans: Engineering-geologic mapping will be carried out with helicopter support from August 6 through August 31. The proposed Arctic Gas Pipeline route crosses this region which is within the continuous permafrost zone.
Engineering-geologic studies are critical because permafrost poses unusual and serious engineering problems relating to the design, construction and maintenance of all types of structures.

In addition, observations will be made along the trans-Alaska oil pipeline route between Prudhoe Bay and the summit of the Brooks Range in order to obtain pertinent geotechnical data relating to the construction and operation of the pipeline and haul road.

Project: Quaternary geology of the central Brooks Range.

Region and map key: Northern Alaska, Philip Smith Mountains and Chandalar quadrangles (5).

Organizational designation: Geologic Division, Office of Mineral Resources, Branch of Alaskan Geology.

Project chief: Thomas D. Hamilton, U.S. Geological Survey, 345 Middlefield Road, Menlo Park, Calif. 94025; [415] 323-8111, ext. 2156.

Project plans: The main objectives of the project 
are the preparation of reconnaissance-scale surficial geologic maps for the central Brooks Range and the development of a stratigraphic framework for the Quaternary deposits of this region.

Mapping of the Philip Smith Mountains and Chandalar 1:250,000 quadrangles will be completed during 1975. Stratigraphic exposures along rivers in these map areas will be studied in detail and, where present, organic remains will be recovered for species identification and radiocarbon dating. Surficial geologic mapping will be extended westward across the central Brooks Range during subsequent summers to cover the following 1:250,000 quadrangles: Chandler Lake, Wiseman, Killik River, Survey Pass, Howard Pass, and Ambler River.

A 6-week helicopter-supported field season is planned for the summer of 1975 . Field headquarters for Thomas Hamilton and his assistant, Robert Thorson, will be at Galbraith Lake and Chandalar Lake.

Project: AMRAP and Philip Smith Mountains Quadrangle.

Region and map key: Northern Alaska, Philip Smith Mountains quadrangle (6).

Organizational designation: Geologic Division, Office of Mineral Resources, Branch of Alaskan Geology.

Team leaders: Hillard N. Reiser and William P. Brosgé, U.S. Geological Survey, 345 Middlefield Road, Menlo Park, Calif. 94025; [415] 323-8111, ext. 2387 and 2316 respectively.

Project plans: Reconnaissance geologic mapping at 1:250,000 scale, coupled with continued detailed biostratigraphic studies of the Lisburne and Sadlerochit Groups, will be conducted with the objective of refining existing paleo- and biostratigraphic interpretations of these rocks. Substantive evidence will also be sought pertaining to the question of large scale tectonic displacement of the rocks which constitute the Central Brooks Range. The mapping to be accomplished will tie to that of the Chandalar quadrangle immediately to the south and will be fundamental to the interpretation of geochemical sampling being conducted there this summer and extended and completed in the Philip Smith quadrangle in 1976. R. L. Detterman will be primarily concerned with stratigraphic studies in the Mississippian and post-Mississippian rocks respectively. $\mathrm{H}$. N. Reiser, W. P. Brosgé, and J. T. Dutro, Jr. will primarily be concerned with the mapping and structural interpretation of the area. The field party, which will be based at the Galbraith Lake pipeline construction camp, will have David Orchard as field assistant. Fieldwork will begin June 1 and continue into August. Communication with the field party may be made through either the U.S. Geological Survey office in Fairbanks or the Alyeska Pipeline Service Company.

\section{Project: Eastern Brooks Range.}

Region and map key: Northern and east-central Alaska, parts of Coleen, Demarcation Point, Table Mountain, Christian, Arctic, Mt. Michelson quadrangles (7).

Organizational designation: Topographic Division, Rocky Mountain Mapping Center.

Project chief: A. E. Letey, Rocky Mountain Mapping Center, Denver, Colo. 80225; [303] 234 3131, ext. 2351.

Project plans: Field control was obtained during the 1972 field season. Sixteen 1:63,360-scale quadrangles have been published and 13 others have advanced manuscript copy available. Twenty-eight additional quadrangles have field control and will be compiled as soon as aerial photography is obtained.

No field operations are scheduled for the 1975 field season.

\section{EAST-CENTRAL ALASKA}

Project: AMRAP and Chandalar quadrangle.

Region and map key: East-central Alaska (8).

Organizational designation: Geologic Division, Office of Mineral Resources, Branch of Exploration Research and Branch of Alaskan Geology. Party chief: Sherman P. Marsh, Branch of Exploration Research, U.S. Geological Survey, Bldg. 25, Federal Center, Denver, Colo. 80225; [303] 234-3131, ext. 3852. (W. P. Brosgé and H. N. Reiser, Branch of Alaskan Geology, Menlo Park, are the team leaders for AMRAP in the Chandalar quadrangle, but will be in the field in the adjacent Philip Smith quadrangle in 1975.)

Project plans: During July and August Sherman P. Marsh, aided by a geochemist and three field assistants, will make a geochemical sample survey of the entire quadrangle. Milton A. Wiltse and a field assistant, both of the State of Alaska 


\begin{tabular}{llll}
\hline \multicolumn{1}{c}{ Name of project } & Personnel & Type of work & Area(s) \\
\hline $\begin{array}{l}\text { Chandalar quad } \\
\text { Wiltse }\end{array}$ & $\begin{array}{l}\text { Sherman P. Marsh, Milton A. } \\
\text { (AMRAP) }\end{array}$ & $\begin{array}{l}\text { Geochemical survey; } \\
\text { sampling of known } \\
\text { prospects }\end{array}$ & Chandalar quadrangle \\
\hline $\begin{array}{l}\text { Yukon-Tanana Upland } \\
\text { Helen Foster, Florence } \\
\text { Weber, Terry Keith, Tom } \\
\text { Hessin }\end{array}$ & $\begin{array}{l}\text { Geologic mapping } \\
\text { geochemical sampling }\end{array}$ & Big Delta quadrangle \\
\hline
\end{tabular}

Division of Geological and Geophysical Surveys, will map and sample some of the known prospects during approximately 3 weeks in July and August. Gravity data will be collected in late August by a U.S. Geological Survey geophysicist. The field party will be supported by a helicopter and will be based at a cabin near the Chandalar Lake airstrip. The mailing address will be U.S.G.S. Chandalar Camp, c/o Betty McIntire, Administrative Division, U.S. Geological Survey, $218 \mathrm{E}$ Street, Anchorage, Alaska 99501. Radio phone-patch communication will be on frequencies 3211 and 5167.5 through [907] 344-9811 (Anchorage).

Project: AMRAP and Yukon-Tanana Upland.

Region and map key: East-central Alaska, Big Delta quadrangle (9).

Organizational designation: Geologic Division, Office of Mineral Resources, Branch of Alaskan Geology.

Team leader: Helen L. Foster, U.S. Geological Survey, 345 Middlefield Road, Menlo Park, Calif. 94025; [415] 323-8111, ext. 2331.

Project plans: Reconnaissance geologic mapping and geochemical sampling will be carried on in the northern half of the Big Delta quadrangle. The field party will headquarter at Chena Hot Springs. During the months of July and August, the geologic party, consisting of Helen Foster,
Florence Weber, Terry Keith, and a field assistant, will be supported by helicopter. During August, Tom Hessin and three assistants will carry on a helicopter-supported geochemical sampling program which will be closely coordinated with the geologic mapping.

\section{WEST-CENTRAL ALASKA}

Project: Ruby quadrangle.

Region and map key: West-central Alaska, chiefly southern three-fourths of the Ruby quadrangle (10).

Organizational designation: Geologic Division, Office of Mineral Resources, Branch of Alaskan Geology.

Project chief: Robert M. Chapman, U.S. Geological Survey, 345 Middlefield Road, Menlo Park, Calif. 94025; [415] 323-8111, ext. 2670.

Project plans: Reconnaissance geologic mapping with helicopter support will be done in the portion of the Ruby quadrangle south of $64^{\circ} 45^{\prime} \mathrm{N}$., during the last 3 weeks in August. The party, consisting of R. M. Chapman and W. W. Patton, Jr., tentatively will be based first at Lake Minchumina and later at Galena.

Investigations will be directed primarily toward identifying the major bedrock units in the Ruby quadrangle, which presently is incom-

West-central Alaska

\begin{tabular}{llll}
\hline Ruby quadrangle & $\begin{array}{c}\text { Robert M. Chapman, W. W. } \\
\text { Patton, Jr. }\end{array}$ & $\begin{array}{c}\text { Geologic mapping, } \\
\text { geochemical sampling }\end{array}$ & Ruby quadrangle \\
\hline $\begin{array}{l}\text { Nixon Fork stratigraphic } \\
\text { studies }\end{array}$ & $\begin{array}{l}\text { W. W. Patton, Jr., J. Thomas } \\
\text { Dutro, Jr., Robert M. } \\
\text { Chapman }\end{array}$ & Stratigraphic studies & Medfra quadrangle \\
\hline Nome & C. L. Hummel & $\begin{array}{c}\text { Compilation to determine } \\
\text { controls of mineralization }\end{array}$ & $\begin{array}{c}\text { Southwestern Seward } \\
\text { Peninsula }\end{array}$ \\
\hline
\end{tabular}




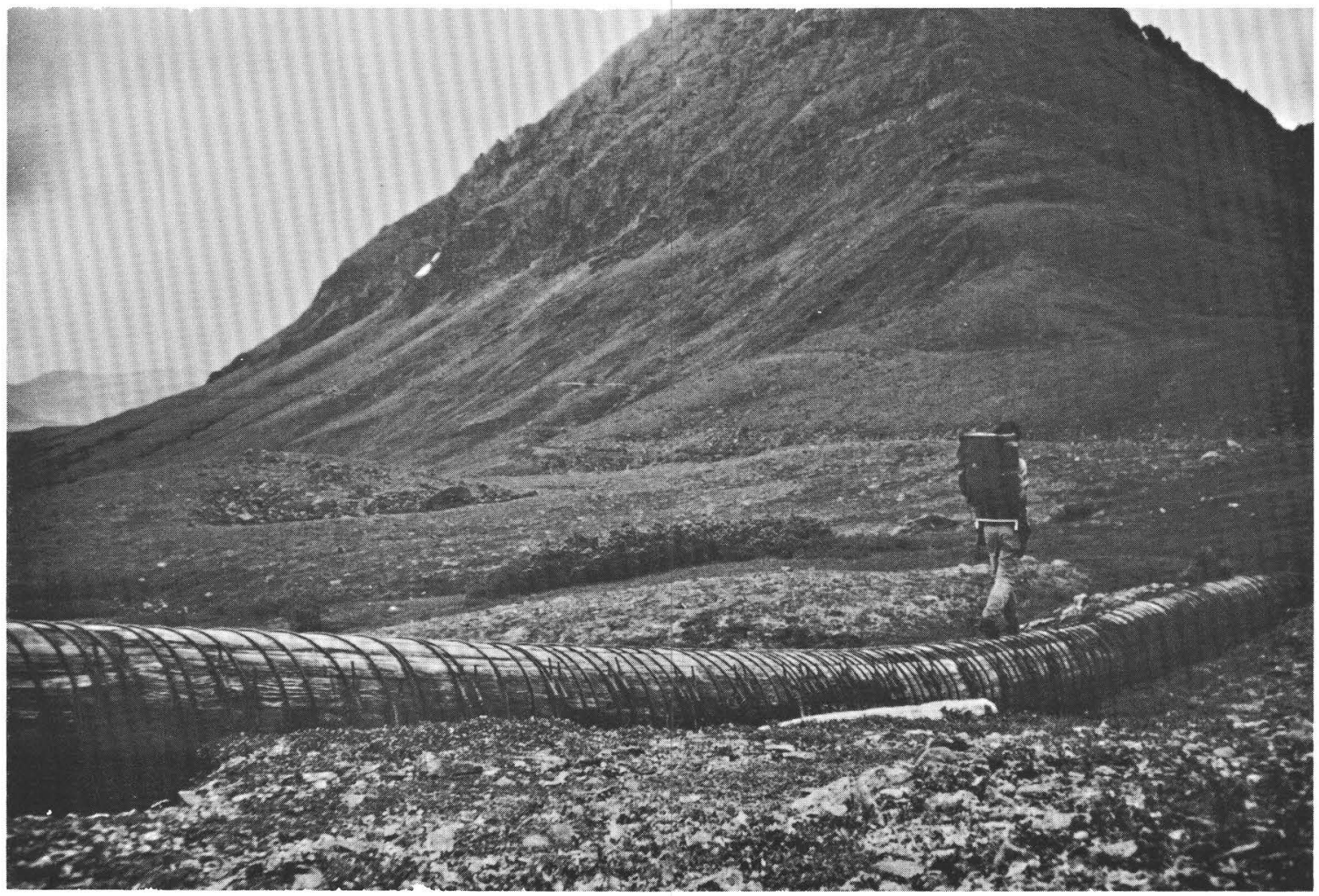

FIGURE 8.-A wood-stave pipeline, constructed for water diversion to mining projects in the Nome River valley, provided easy walking through some parts of the Grand Central River Valley.

pletely known geologically. Pertinent data will be gathered to extend structural trends and rock units along the Ruby geanticline between the Kantishna River and Nulato quadrangles, in which geologic mapping was completed in 1974. Sampling of bedrock and stream sediment for geochemical analysis and mapping of unconsolidated deposits will be done also, as time permits.

Project: Nixon Fork stratigraphic studies (Hughes-Shungnak).

Region and map key: West-central Alaska, Medfra quadrangle (11).

Organizational designation: Geologic Division, Office of Mineral Resources, Branch of Alaskan Geology.

Project chief: William W. Patton, Jr., U.S. Geological Survey, 345 Middlefield Road, Menlo Park, Calif. 94025; [415] 323-8111, ext. 2248.

Project plans: Stratigraphic investigations of the Paleozoic and Mesozoic section in the Nixon Fork region will be undertaken by William W.
Patton, Jr., J. Thomas Dutro, and R. M. Chapman. These investigations are part of a longrange program for geologic mapping and mineral resource evaluation of the Ruby geanticline. The Nixon Fork region is of particular interest because it is one of the few areas in the densely vegetated terrain of the Ruby geanticline with good exposures of the Paleozoic and Mesozoic strata. The exposed sequence is reported to include fossiliferous Ordovician, Silurian, Devonian(?), Permian, and Cretaceous beds. The region is also of interest because it is transected by the Iditarod-Nixon Fork lineament, a suspected strike-slip fault, which has been traced northeasterly across west-central Alaska for more than $400 \mathrm{~km}$.

The field party will operate by helicopter from a base at Medfra during late July and early August.

Project: Nome.

Region and map key: West-Central Alaska (32). 
Organizational designation: Geologic Division, Office of Mineral Resources, Branch of Alaskan Geology.

Project chief: C. L. Hummel, U.S. Geological Survey, 345 Middlefield Road, Menlo Park, Calif. 94025; [415] 323-8111, ext. 2606.

Project plans: General project plans for the coming year are to complete compilation and correlation of all geoscientific information available for the bedrock and lodes of southwest Seward Peninsula in order to determine the regional controls of the primary mineralization. Fieldwork during the summer will comprise mainly detailed investigations of the bedrock geology and mineral deposits and geochemical sampling at numerous localities throughout the area.

\section{SOUTHWESTERN ALASKA}

Project: Western Alaska Cenozoic.

Region and map key: Southwestern Alaska (12).

Organizational designation: Geologic Division, Office of Mineral Resources, Branch of Alaskan Geology.

Project chief: D. M. Hopkins, U.S. Geological Survey, 345 Middlefield Road, Menlo Park, Calif. 94025; [415] 323-8111, ext. 2659.

Project plans: Three weeks in early June will be spent on the Pribilof Islands attempting to date frequency of faulting and volcanic eruptions and stability of the coastline.

Project: Bering Sea.
Region and map key: Southwestern f laska (13).

Organizational designation: Geologic Division, Office of Energy Resources, Branch of PacificArctic Geology.

Project chief: M. S. Marlow, U.S. Gec'logical Survey, 345 Middlefield Road, Menlo Park, Calif. 94025; [415] 323-8111, ext. 2656.

Project plans: Current plans are for $\varepsilon$. two month geophysical and geological survey of the southern Bering Sea shelf and adjacent slope and ba$\sin$. The R/V S.P. Lee will be equiprod to collect 24 channel seismic reflection, gravity, magnetic, bathymetric, and intermediate and high resolution seismic reflection data during the summer of 1975 . Dredge, core, and grab samples will also be taken.

Project: AMRAP Goodnews-Hagemeister Island and Southwestern Alaska.

Region and map key: Southwestern Alaska; Goodnews and Hagemeister Island quadrangles (15).

Organizational designation: Geolog:c Division, Office of Mineral Resources, Branct of Alaskan Geology.

Team leaders: W. L. Coonrad (AMRAP) and J. M. Hoare (Southwestern Alaska), U.S. Geological Survey, 345 Middlefield Road, Menlo Park, Calif. 94025; [415] 323-8111, ext. 2608 and 2372 respectively.

Project plans: The objective of the AMRAP program is to obtain improved mineral resource information and the major objective of the Southwestern Alaska project is to upgrade basic

Southwestern Alaska

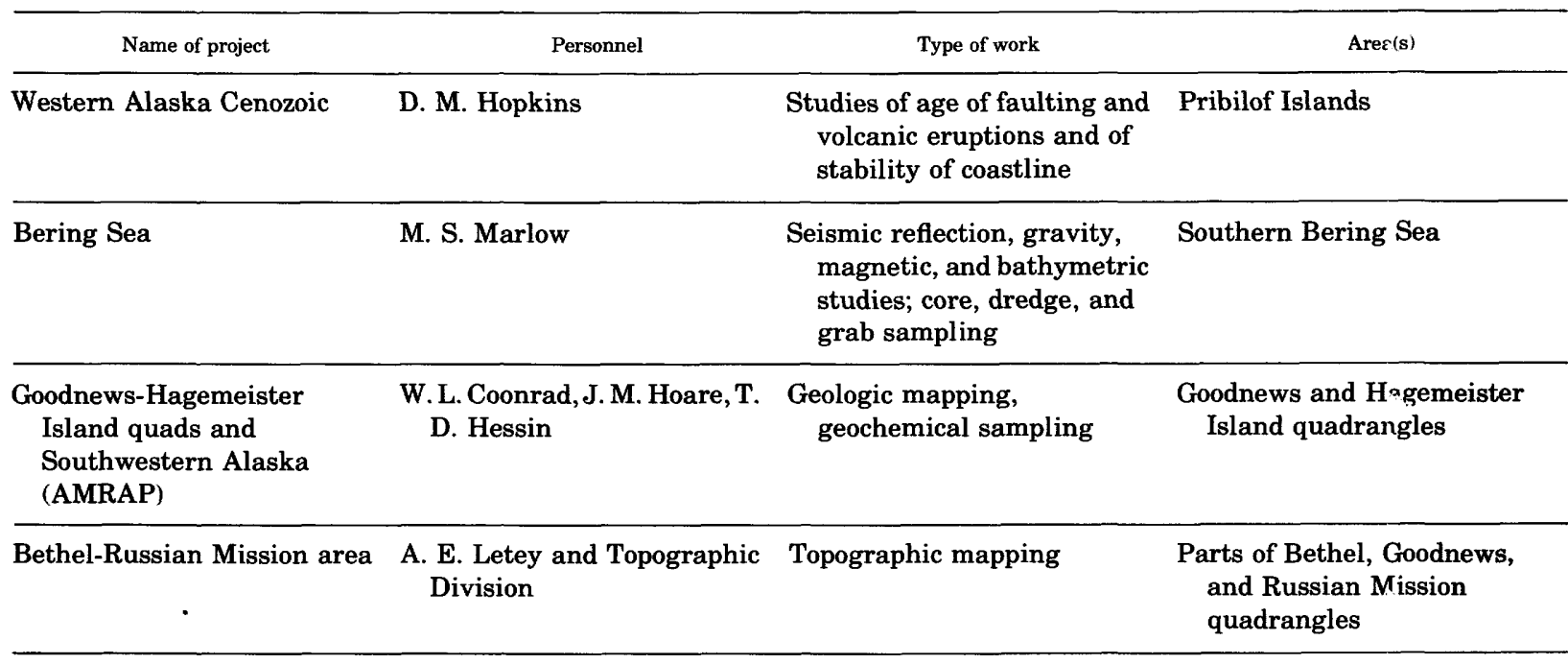


geologic knowledge in the region. Helicopter supported reconnaissance geologic mapping and geochemical sampling will start on July 1 and extend through August in the Goodnews and Hagemeister Island quadrangles. Personnel will include W. L. Coonrad, J. M. Hoare, two assistants, and a cook for the entire period, and during July, a five-person geochemical sampling party headed by T. D. Hessin (BOER, Denver). The field party will be headquartered at Twin Hills Village near the head of Togiak Bay and can be contacted through Kodiak Western Alaska Airlines at Dillingham.

Project: Bethel-Russian Mission area.

Region and map key: Southwestern Alaska, parts of Bethel, Goodnews, and Russian Mission quadrangles (16).

Organizational designation: Topographic Division, Rocky Mountain Mapping Center.

Project chief: A. E. Letey, Rocky Mountain Mapping Center, Denver, Colo. 80225; [303] 234 3131, ext. 2351.

Project plans: This project area consists of mapping 24 1:63,360-scale quadrangles, which are being compiled using Air Force aerial photography and existing control. No field operations are scheduled for this project.

\section{SOUTHERN ALASKA}

Project: PAMRAP and Talkeetna quadrangle.

Region and map key: Southern Alaska, Talkeetna quadrangle (17).

Organizational designation: Geologic Division, Office of Mineral Resources, Branch of Alaskan Geology.

Team leader: Bruce Reed, U.S. Geological Survey, 1209 Orca Street, Anchorage, Alaska 99501; [907] 272-8228.

Project plans: Fieldwork plans for this project were unavailable at press time.

Project: AMRAP and Talkeetna Mountains.

Region and map key: Southern Alaska, Talkeetna Mountains quadrangle (18).

Organizational designation: Geologic Division, Office of Mineral Resources, Branch of Alaskan Geology.

Team leader: Béla Csejtey, Jr., U.S. Geological Survey, 345 Middlefield Road, Menlo Park, Calif. 94025; [415] 323-8111, ext. 2277.
Project plans: Starting July 1, 1975, the ongoing Talkeetna Mountains geological and geochemical mapping project will merge with the recently initiated Alaskan Mineral Resource Assessment Program (AMRAP). The aims cf AMRAP are described elsewhere in this circular.

Field plans call for a helicopter-supported program of reconnaissance geological mapping and detailed mineral resource investigations, and a concurrent program, supported by a second helicopter, of geochemical sampling and research. During the 1975 field season, the two activities will cover the western half of the Talkeetna Mountains quadrangle.

Geologic investigations will be done between July 1 and August 31 on a full-time basis by Béla Csejtey, Jr., and Willis H. Nelson, geologists, and by Robert M. Dean and Michael S. Morris, field assistants. The mineral resource investigations will be conducted by Miles L. Silberman and Edward M. MacKevett, Jr., geoloxists. Consultants and part-time field workers include geologists Nairn R. D. Albert, Paul C. Bateman, David L. Jones, Marvin A. Lanphere, A. Thomas Ovenshine, and James G. Smith, all of the U.S. Geological Survey, and Peter J. Coney of Middlebury College.

The geochemical investigations will be carried out between July 15 and August 15 by Gary C. Curtin, geochemist, and by field assistants Richard C. Karlson, Steven P. Johnson, and Lawrence Garmezy.

Field headquarters for all participants will be in the town of Talkeetna.

Project: Glaciology studies.

Region: Southern Alaska.

Organizational designation: Water Resources Division, Alaska District Office.

Project chief: L. R. Mayo, U.S. Geological Survey, 310 First Avenue, Fairbanks, Alaska, 99701; [907] 452-1951, ext. 176.

Project plans: The overall objective of this project is to monitor the mass balance, ice physics, and motion of representative glaciers in Alaska. Emphasis of work will be changed from detailed annual studies of data collected on Gulkana and Wolverine Glaciers to long-term studies of ice physics, motion, and balance (McCall Glacier may be added to this study). The projent staff will expand aerial photography reconneissance to 


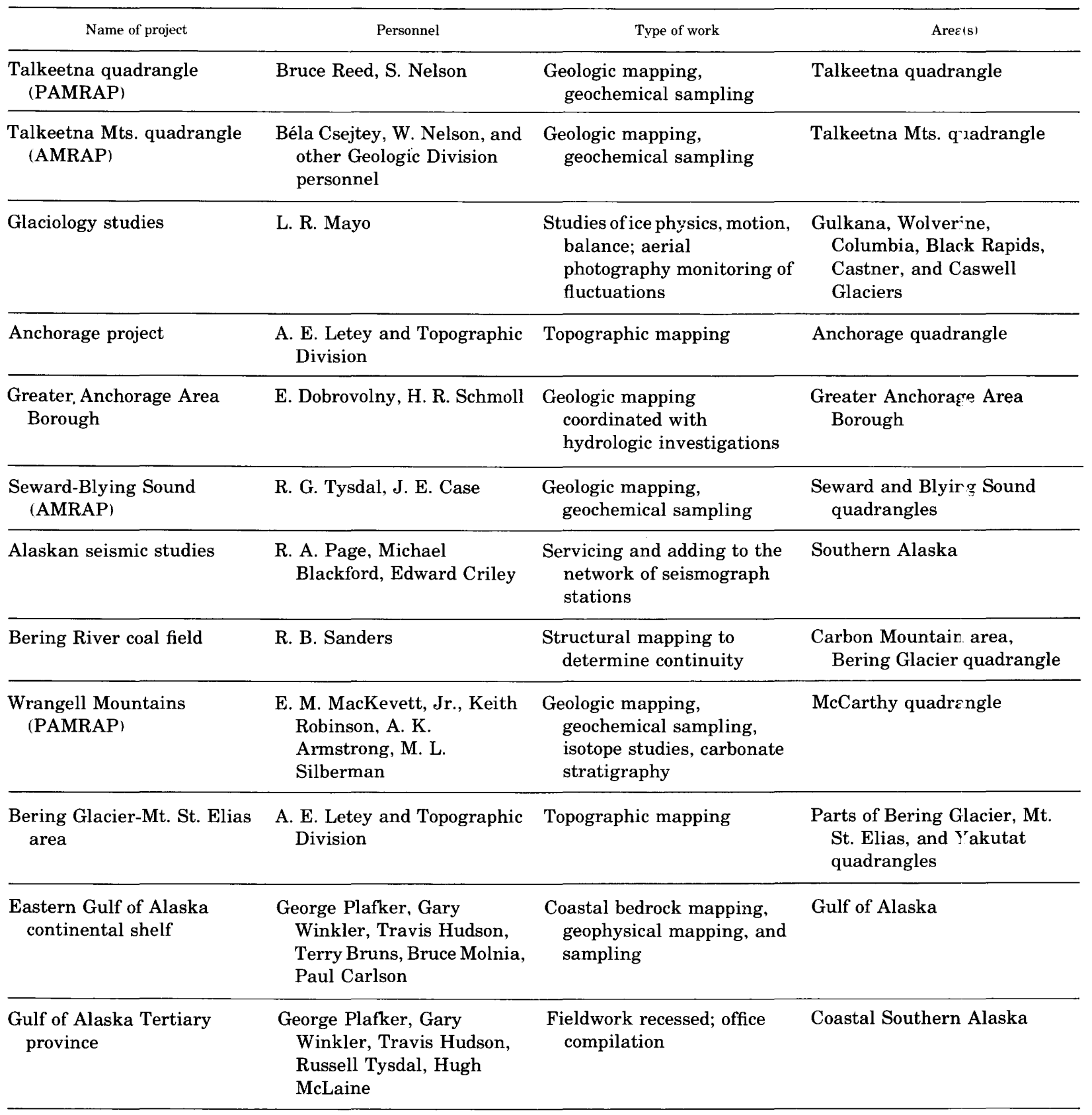

include glaciers of interest to the TAPS program as well as Gulkana, Wolverine, and Columbia Glaciers; study the fluctuations, balance, and regimes of Black Rapids, Castner, and Caswell Glaciers with emphasis on theoretical studies of surging; install instruments for monitoring glacier dammed lakes; collect and examine data from staff readings of aufeis; continue detailed longitudinal profiling on Black Rapids Glaciers; and set up the survey network for similar studies on Castner and Caswell Gleriers.

Project: Anchorage project.

Region and map key: Southern Alaska, Anchorage quadrangle (20).

Organizational designation: Topographic Division, Rocky Mountain Mapping Certer. 
Project chief: A. E. Letey, Rocky Mountain Mapping Center, Denver, Colo. 80225; [303] 2343131, ext. 2351.

Project plans: The Anchorage project consists of topographic mapping of 31 quadrangles at a scale of $1: 25,000$ with contour intervals of 5,10 , or $20 \mathrm{~m}$. The project area includes the city of Anchorage, and extends north to the towns of Willow, Palmer, and Jonesville. Sixteen of these quadrangles are standard line maps for which advance manuscript copy will be available by Spring 1975. The remaining 15 quadrangles are orthophotomaps that will have advance copy (monocolor orthophotoquads) available by mid-Summer 1975.

Field operations are complete, and none are scheduled for the 1975 season.

Project: Greater Anchorage Area Borough, Alaska.

Region and map key: Southern Alaska, Greater Anchorage Area Borough (21).

Organizational designation: Geologic Division, Office of Environmental Geology, Branch of Engineering Geology.

Project chief: E. Dobrovolny, U.S. Geological Survey, Denver Federal Center, Denver, Colo. 80225; [303] 234-3131, ext. 3471.

Project plans: The project involves detailed geologic mapping of the Anchorage and vicinity area, at a scale of $1: 24,000$, and reconnaissance geologic mapping of the remainder of the Greater Anchorage Area Borough, at a scale of 1:63,360, with emphasis on Quaternary deposits. The objective is to provide geologic information needed for citywide and boroughwide land-use planning. The studies were undertaken in response to requests from local government officials and are closely coordinated with hydrologic investigations by the USGS Water Resources Division. Fieldwork has been completed, and maps and reports are in preparation. Special-purpose maps are being prepared from the geologic maps for use by planners and developers. Several interpretive maps have already been released and others are in the process of being completed. Assigned personnel: E. Dobrovolny and $H$. R. Schmoll.

Project: AMRAP and Seward-Blying Sound. Region and map key: Southern Alaska, Seward and Blying Sound quadrangles (22).
Organizational designation: Geologic Division, Office of Mineral Resources, Branch of Alaskan Geology.

Team leader: R. G. Tysdal, U.S. Geological Survey, 345 Middlefield Road, Menlo Park, Calif. 94025; [415] 323-8111, ext. 2613.

Project plans: The project objective for this summer is reconnaissance geologic mapping (at a scale of $1: 250,000$ ) in the central ard western parts of the Seward and Blying Sound quadrangles. Plans also call for about 2 weeks of geochemical sampling in two separate areas within the quadrangles. The helicopter-supported mapping will be conducted by R. G. Tysdal and J. E. Case from mid-June to mid-August. This year's study is the initial effort in making a geologic map and a mineral resource survey of the Seward-Blying Sound area.

Project: Alaskan Seismic studies.

Region: Southern Alaska.

Organizational designation: Geologic Division, Office of Earthquake Studies, Branch of Seismology.

Project chief: Robert A. Page, U.S. Geological Survey, 345 Middlefield Road, Menlo Park, Calif. 94025; [415] 323-8111, ext. 2461.

Project plans: The principal goals of this project are to develop an understanding of the tectonic processes that generate earthquake in southern Alaska, to evaluate seismic hazards in south central Alaska and the Gulf of Alaska region, and to initiate long-term seismic and crustal deformation measurements aimed at documenting premonitory earthquake phenomena.

Earthquakes are recorded by a network of 51 seismograph stations extending from Katmai National Monument north and east through Cook Inlet, the Kenai Peninsula, Northern Prince William Sound, and the Chugach Mountains to Yakutat. The data are recorded at the Palmer Seismological Observatory of the National Oceanic and Atmospheric Administration under a cooperative earthquake recording program. Information and results from this project are published in the form of maps of epicenters, catalogs of earthquakes, and scientific reports and articles. Two biaxial tiltmeters are operating on Middleton Island on the etge of the continental shelf in the Gulf of Alaska.

During the 1975 season, in addition to servicing current stations, up to 11 additional 
stations will be added to the network to improve coverage around northern Cook Inlet, west of Valdez, and east of Cordova. Michael Blackford and Edward Criley will supervise this work out of Anchorage.

Project: Bering River Coal Field.

Region and map key: Southern Alaska (23).

Organizational designation: Conservation Division, Office of the Area Geologist, Alaska Area. Project chief: R. B. Sanders, U.S. Geological
Survey, P. O. Box 259, Anchorage, Alaska 99501.

Project plans: The Carbon Mountain area at the eastern end of the coal field will be mapped at $1: 48,000$ with emphasis on coal occurrences. It is predicted that the structure is less complex in this area.

The Carbon Mountain area on the eastern limit of the known extent of the Bering River Coal Field will be mapped at 1:63,360. Coal exposures will be studied to ascertain coal seam

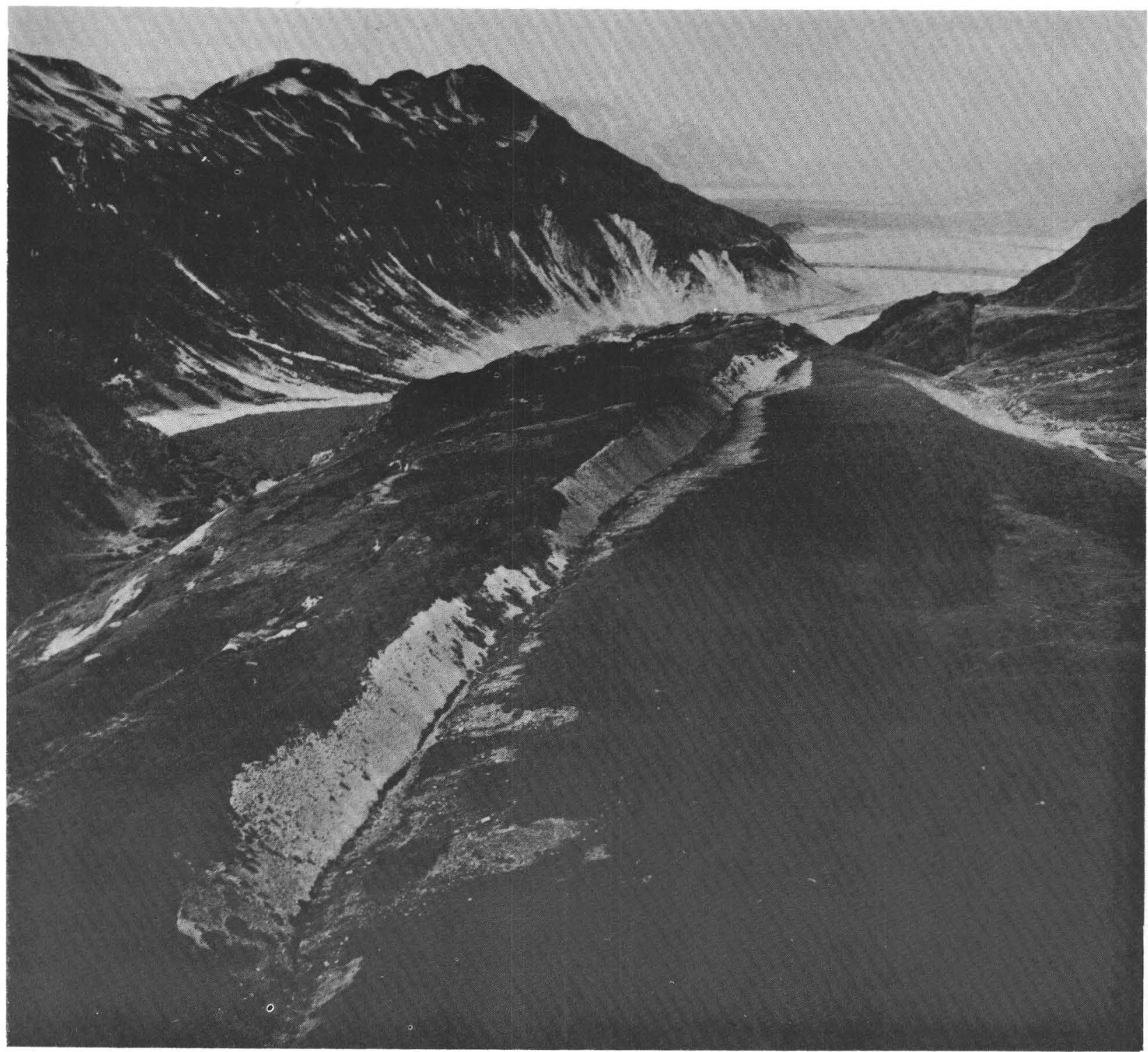

Figure 9.-The Alsek-Grand Plateau fault cuts a moraine in the Skagway A-8 quadrangle; looking to the northwest up the Alsek River valley. 
continuity and persistence. Because current stratigraphic nomenclature does not meet the needs of field workers, the region shall be studied in hopes of establishing a more suitable stratigraphy in the lower Tertiary sequences.

Project: Wrangell Mountains.

Region and map key: Southern Alaska (24).

Organizational designation: Geologic Division, Office of Mineral Resources, Branch of Alaskan Geology.

Project chief: E. M. MacKevett, Jr., U.S. Geological Survey, 345 Middlefield Road, Menlo Park, Calif. 94025; [415] 323-8111, ext. 2216.

Project plans: Fieldwork on the project was completed during the 1974 season under the aegis of PAMRAP. The fieldwork comprised: (1) completing reconnaissance geologic mapping of the McCarthy 1:250,000 quadrangle, (2) completing a reconnaissance geochemical survey of the quadrangle (under the direction of Keith Robinson, BOER), (3) studies by A. K. Armstrong that focused on the roles of carbonate stratigraphy and petrology in the genesis of the Kennecott-type copper deposits, and (4) investigations by $M$. L. Silberman that involved collecting rock and ore samples for isotope studies.

The project's objectives, which have been largely fulfilled, include providing modern multi-purpose geologic maps of the McCarthy quadrangle, a sound understanding of the quadrangle's geology and its relationship to regional geologic and tectonic settings, and a basis for judicious mineral resource appraisal. Many of the results of this project have been published as maps and reports during the past several years; additional results will be conveyed in reports and maps that are in preparation or in those that are planned. The latter will incorporate results of current laboratory and office investigations.

Project: Bering Glacier-Mount St. Elias area.

Region and map key: Southern Alaska, parts of Bering Glacier, Mt. St. Elias and Yakutat quadrangles (25).

Organizational designation: Topographic Division, Rocky Mountain Mapping Center.

Project Chief: A. E. Letey, Rocky Mountain Mapping Center, Denver, Colo. 80225; [303] 234-3131, ext. 2351.
Project plans: This project area consists of mapping 50 1:63,360-scale quadrangles, which will be compiled using Air Force aerial photography and existing control. No field operations are scheduled for this project.

Project: Eastern Gulf of Alaska continental shelf. Region: Southern Alaska (26).

Organizational designation: Geologic Division, Office of Energy Resources and Marine Geology, Pacific-Arctic Branch.

Project chief: George Plafker, U.S. Geological Survey, 345 Middlefield Road, Menlo Park, Calif. 94025; [415] 323-8111, ext. 2201.

Project plans: For 2 weeks during June, George Plafker, Gary Winkler, and Travis Hudson will carry out reconnaissance studies of pre-Tertiary bedrock along the coast of the Lituya district and will measure and sample selected Tertiary sections. The party will be helicopter-supported and based on the R/V Don J. Miller. The geologic work is planned to help identify geophysicallydefined units on the adjacent continental shelf.

During the summer of 1975, approximately 3,000 line miles of 48-channel seismic reflection data will be obtained with a contract ship and equipment, as part of the Geological Survey's program for evaluating the resource potential of the Gulf of Alaska outer continental shelf(OCS). Terry Bruns, George Plafker, and other Survey personnel will participate in the cruise. In addition, during the period April 1 through June 10, Bruce Molnia, Paul Carlson, and others will spend approximately 40 days aboard the NOAA ship Surveyor and 17 days aboard the NOAA ship Cromwell to carry out environmentallyoriented geologic research on the eastern Gulf of Alaska OCS. As part of this research, they plan to obtain detailed high-resolution seismic profiles and related geophysical data, and will collect a suite of bottom sediment samples.

Project: Gulf of Alaska Tertiary province.

Region: Southern Alaska.

Organizational designation: Geologic Division, Office of Mineral Resources, Branch of Alaskan Geology.

Project chief: George Plafker, U.S. Geological Survey, 345 Middlefield Road, Menlo Park, Calif. 94025; [415] 323-8111, ext. 2201.

Project plans: This is an ongoing project aimed at delineation of the major geologic features of the 
Tertiary basin, evaluation of its resources, and study of the adjacent pre-Tertiary terranes. Fieldwork has been recessed for the 1975 season. Work in preparation for publication includes (1) an analysis of Tertiary sandstone reservoir characteristics, (2) a paper on the Paleogene Orca Group, (3) a paper on intrusive igneous rocks of the Saint Elias Mountains, (4) a $1: 31,680$-scale geologic map of Kayak and Wingham Islands, (5) a 1:63,360 geologic map and report on the central Katalla district, (6) a geologic map of the Ragged Mountains (Cordova A2, B2 quads), and (7) reconnaissance geologic maps of the Yakutat, Mt. Saint Elias, Bering Glacier, Icy Bay, Cordova, and Middleton Island 1:250,000 quadrangles. In addition to George Plafker, personnel involved in this project are Gary Winkler, Travis Hudson, Russell Tysdal, Hugh MacLaine, and Marvin Lanphere.

\section{SOUTHEASTERN ALASKA}

Project: Juneau, Alaska, regional mapping and related geologic investigations.

Region and map key: Southeastern Alaska, Juneau and Taku River quadrangles (28).

Organizational designation: Geologic Division, Office of Mineral Resources, Branch of Alaskan Geology.

Project chief: D. A. Brew, U.S. Geological Survey, 345 Middlefield Road, Menlo Park, Calif. 94025; [415] 323-8111, ext. 2178.

Project plans: During the middle part of June, geologists D. A. Brew, A. B. Ford, C. J. Nutt, and C. Carlson will be engaged in field studies of granitic and metamorphic rocks in the upper

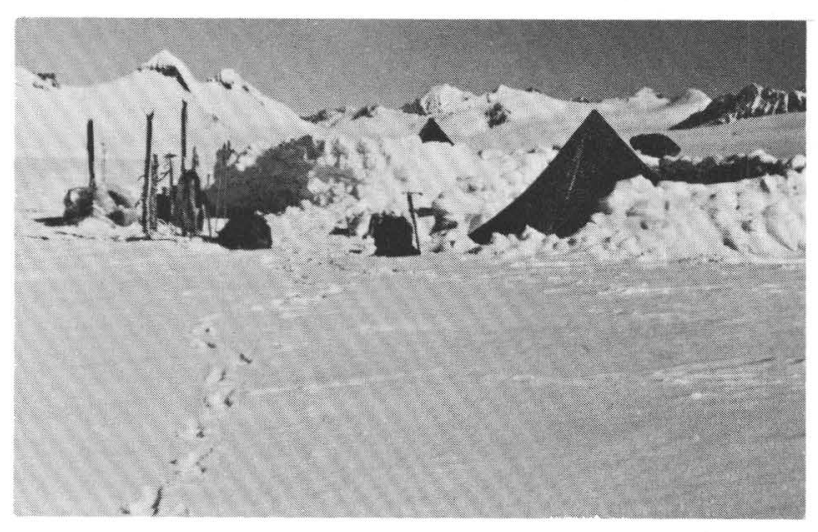

Figure 10.-Field camp on the Juneau Icefield.
Gilkey Glacier area immediately adjacent to the Juneau Icefield proper. These studies are part of the continuing effort to complete the geologic mapping and mineral resource survey of this part of the Coast Range.

The field party will operate from Camp 18A of the Juneau Icefield Research Program and from spike camps, using skis when possible. The party will be placed in the field by helicopter. Radio contact will be through Livingston 'Copters, Inc., Juneau [907] 586-2030. The mailing address will be \% General Delivery, Juneau, Alaska 99801.

Project: Surficial geology of the Juneau urban area and vicinity, Alaska.

Region and map key: Southeastern Alaska, part of Juneau A-2, B-2, and B-3 quadrangles, $1: 63,360$ (29).

Organizational designation: Geologic Division, Office of Environmental Geology, Branch of Engineering Geology.

Project chief: R. D. Miller, U.S. Geological Survey, Denver Federal Center, Denver, Colo. 80225; [303] 234-3131, ext. 2960.

Project plans: Fieldwork has been completed. A geologic map has been transmitted for publication in the Miscellaneous Geologic Investigations Map series, and preparation has started on the final report, to be published as a U.S. Geological Survey Professional Paper. Assigned personnel: R. D. Miller.

Project: Reconnaissance engineering geology of the Sitka area and certain other coastal communities in Alaska including Metlakatla, Hoonah, Yakutat, Naknek, Dillingham, Bethel, and Unalakleet.

Regions: Southeastern, southwestern, and western Alaska.

Organizational designation: Geologic Division, Office of Environmental Geology, Branch of Engineering Geology.

Project chief: L. A. Yehle, U.S. Geological Survey, Denver Federal Center, Denver, Colo. 80225; [303] 234-3131, ext. 2999.

Project plans: The main objective of the project is to evaluate by reconnaissance field studies, geologic hazards, including earthquakes, that affect Sitka and certain other communities in southeastern, southwestern, and western Alas- 


\begin{tabular}{|c|c|c|c|}
\hline Name of project & Personnel & Type of work & Area(s) \\
\hline Juneau regional mapping & $\begin{array}{l}\text { D. A. Brew, A. B. Ford, C. J. } \\
\text { Nutt, C. Carlson }\end{array}$ & $\begin{array}{l}\text { Geologic mapping and } \\
\text { mineral resource survey. }\end{array}$ & $\begin{array}{l}\text { Gilkey Glacier area, Juneau } \\
\text { and Taku River } \\
\text { quadrangles }\end{array}$ \\
\hline Surficial geology, Juneau & R. D. Miller & $\begin{array}{l}\text { Fieldwork complete; } \\
\text { compilation in progress }\end{array}$ & Juneau area \\
\hline Craig quadrangle & $\begin{array}{l}\text { G. Donald Eberlein, Michael } \\
\text { Churkin, Jr., Norman M. } \\
\text { Savage, H. C. Berg, R. L. } \\
\text { Elliott }\end{array}$ & $\begin{array}{l}\text { Geologic mapping, } \\
\text { paleontologic, and } \\
\text { paleomagnetic studies }\end{array}$ & Craig quadrangle \\
\hline Ketchikan quad (AMRAP) & $\begin{array}{l}\text { H. C. Berg, R. L. Elliott, J. G. } \\
\text { Smith, B. D. Wiggins, R. J. } \\
\text { Rudser, R. B. Carten, R. D. } \\
\text { Koch }\end{array}$ & $\begin{array}{l}\text { Geologic mapping, mineral } \\
\text { resource evaluation }\end{array}$ & Ketchikan quadrangle \\
\hline
\end{tabular}

ka. Limited physical properties tests have been performed in the laboratory. Fieldwork has been completed. An open-file report on the engineering of the Sitka area was released in 1974. An open-file report on Metlakatla is in preparation and planned for submittal in 1975. Preparation of reports on other communities will follow. Assigned personnel: L. A. Yehle.

Project: Craig quadrangle.

Region and map key: Southeastern Alaska, Craig quadrangle (30).

Organizational designation: Geologic Division, Office of Mineral Resources, Branch of Alaskan Geology.

Project chiefs: G. Donald Eberlein and Michael Churkin, Jr., 345 Middlefield Road, Menlo Park, Calif. 94025; [415] 323-8111, ext. 2210 and 2256 respectively.

Project plans: From August 18 through September 17 geologists G. Donald Eberlein and Michael Churkin, Jr., accompanied by two assistants, plan to complete field geologic mapping of previously unmapped parts of the Craig 1:250,000 quadrangle (mainly interior Prince of Wales, Suemez and Sukkwan Islands) using the $\mathrm{R} / \mathrm{V}$ Don J. Miller II as a base for helicoptersupported operations. They will be joined during part of that period by Dr. Norman M. Savage (operating under contract, University of Oregon), who will make additional collections from selected limestone localities in connection with his continuing detailed studies of Silurian and Devonian conodont and brachiopod faunas from the Prince of Wales Island area. The field party will also be joined by Dr. R. VanderVoo (University of Michigan), who will initiate

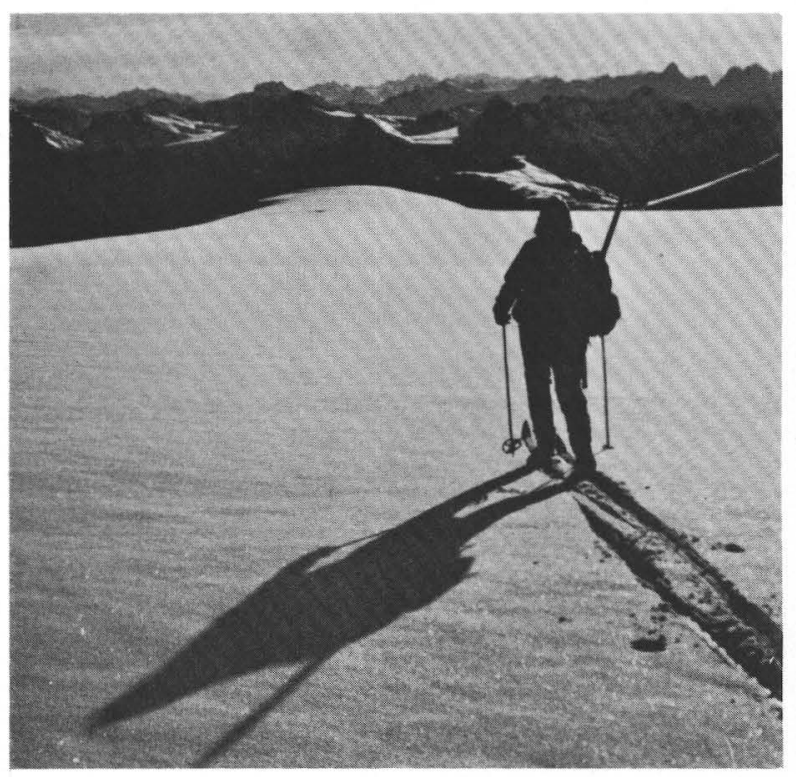

FIGURE 11.-Heading for outcrops on the Juneau Icefield. 
paleomagnetic studies of paleontologically dated units ranging from Precambrian to Permian in age.

In addition, from July 1 to July 10, geologists H. C. Berg, R. L. Elliott and two field assistants, working with a helicopter and a 40 -foot chartered vessel, will extend previously completed mapping of the Annette-Gravina Islands area into the Cleveland Peninsula-Etolin Island area to provide necessary geologic coverage of the Craig C-1, D-1 and D-2 1:63,360 quadrangles. Elliott and the helicopter will be released on July 10 to fulfill other commitments, but Berg and two assistants will continue to work in the area from a second chartered vessel until the end of July.

Project: AMRAP and Ketchikan quadrangle.

Region and map key: Southeastern Alaska, Ketchikan and Craig quadrangles (31).

Organizational designation: Geologic Division, Office of Mineral Resources, Branch of Alaskan Geology.

Team leader: Henry C. Berg, U.S. Geological Survey, 345 Middlefield Road, Menlo Park, Calif. 94025; [415] 323-8111, ext. 2266.

Project plans: From about July 1 to July 10, H. C. Berg and R. L. Elliott, assisted by B. D. Wiggins and R. J. Rudser, will conduct helicoptersupported mapping of the inland areas of western Cleveland Peninsula and southern Etolin Island. During the remainder of July, Berg, assisted by R. B. Carten and R. D. Koch, will complete the mapping of this area with shoreline traverses in outboard skiffs. The Cleveland Peninsula-Etolin Island area lies 30-90 km northwest of Ketchikan and Craig

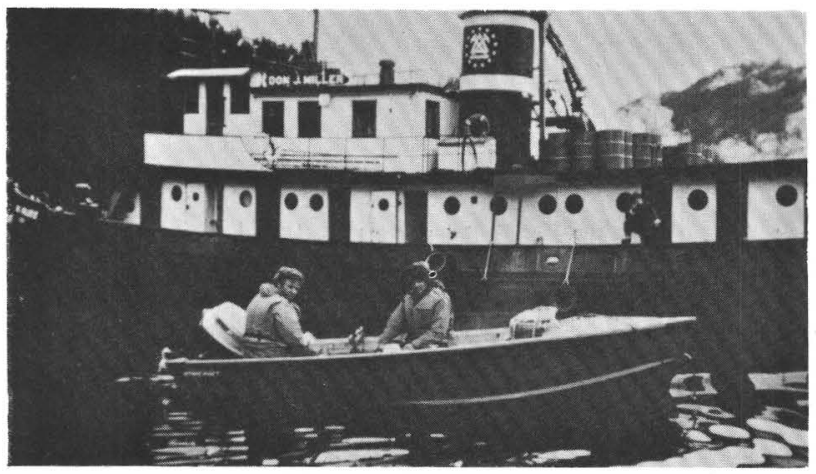

Figure 12.- $R / V$ Don J. Miller $I I$ provides support for fieldwork in watery southeastern Alaska.
1:250,000 scale quadrangles. The study of this area is part of the continuing effort to complete a geologic map and mineral resource survey of the Craig area and also will contribute significantly to a similar understanding of the Ketchikan region.

During August, Berg, Carten, and Koch will conduct shoreline and near-shore mapping on southern Revillagigedo Island, east of Ketchikan.

From approximately July 11 to August 31, Elliott, Rudser and Wiggins will continue helicopter-supported mapping in the eastern part of the Ketchikan quadrangle between East Behm Canal and Portland Canal, about 40-100 $\mathrm{km}$ east of Ketchikan. Mapping will proceed southward from the southern boundary of the previously mapped Granite Fiords Wilderness Study Area.

J. G. Smith will join the field parties for approximately 2 weeks in mid-July to continue his work with K/Ar age determinations of the Coast Range batholithic complex, and to complete mapping of the Ketchikan A-3 quadrangle.

Field parties will operate from chartered boats with weekly supply and mail flights by fixed-wing aircraft from Ketchikan. The mailing address will be: U.S. Geological Survey, P. O. Box 1618, Ketchikan, Alaska 99901.

\section{COOPERATIVE PROJECTS WITH OTHER AGENCIES}

Certain projects of the Geological Survey are undertaken to meet the specific needs of city or state governments or to provide scientific and technical data required by other federal agencies. These projects are funded jointly and are termed cooperative projects. In addition to joint funding, cooperative projects may include combined participation in the scientific work by members of the various participatory agencies.

Listed in this section are the cooperative projects of the U.S. Geological Survey. Most cooperative projects concern the hydrology of Alaska and are statewide in scope. Other cooperative projects have a particular regional focus; the locations of these are shown on the accompanying map (fig. 13).

\section{STATEWIDE PROJECTS}

Project: Statewide water inventory. 


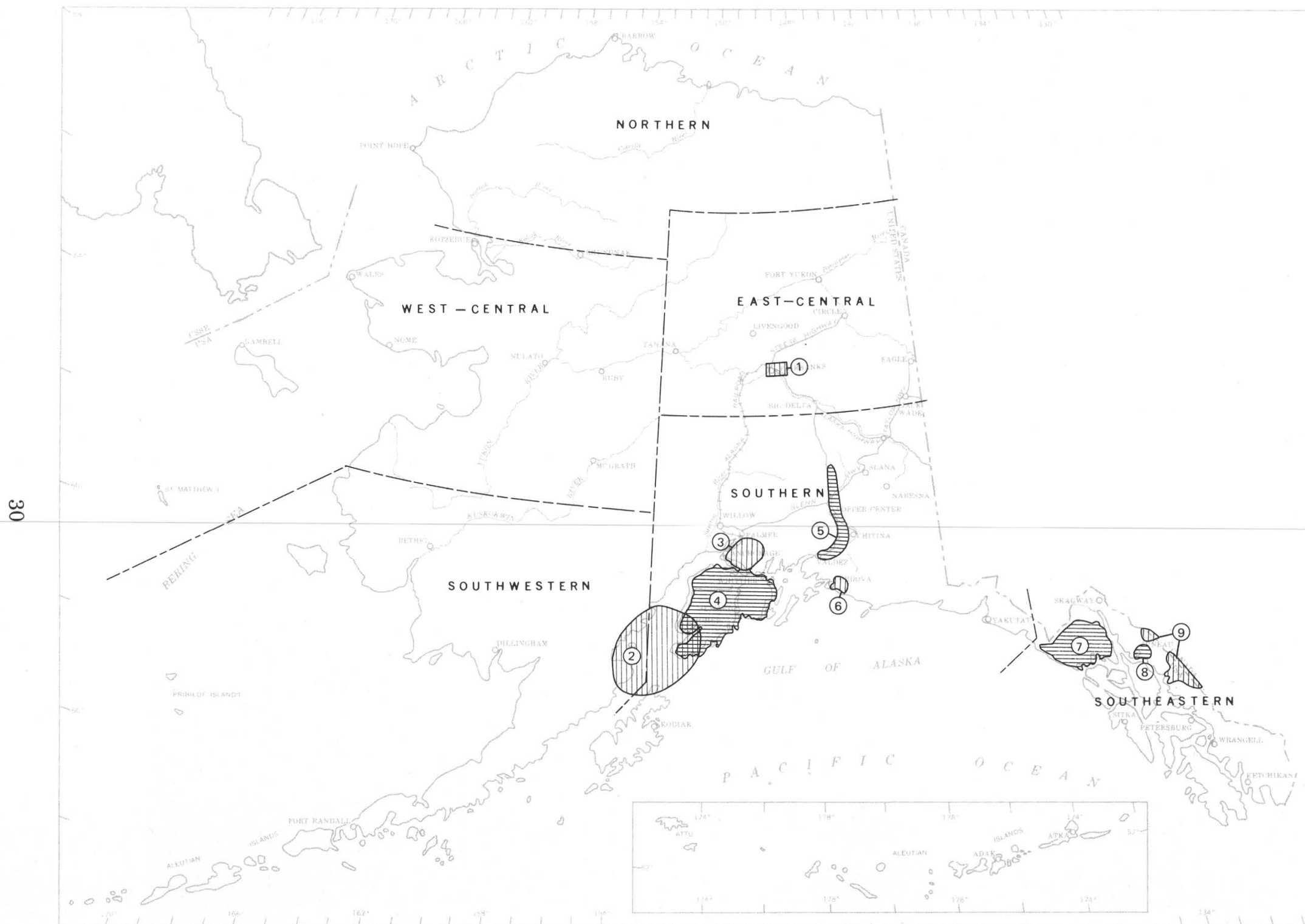

FIGURE 13.-Locations of 1975 field projects of the U.S. Geological Survey and cooperating agencies. 


\begin{tabular}{|c|c|c|c|c|}
\hline Name of project & Project chief & Type of work & Area(s) & Cooperating agencies \\
\hline $\begin{array}{l}\text { Statewide water } \\
\text { inventory }\end{array}$ & G. S. Anderson & $\begin{array}{l}\text { Surface and ground-water } \\
\text { data collection, } \\
\text { processing, filing, and } \\
\text { tabulation }\end{array}$ & Statewide & $\begin{array}{l}\text { State of Alaska, Division of } \\
\text { Geological and Geophysical } \\
\text { Surveys }\end{array}$ \\
\hline $\begin{array}{l}\text { Quality-of-water } \\
\text { stations }\end{array}$ & R. J. Madison & $\begin{array}{l}\text { Monitoring a network of } \\
\text { water-quality stations. }\end{array}$ & Statewide & $\begin{array}{l}\text { U.S. Army Corps of Engineers, U.S. } \\
\text { Forest Service }\end{array}$ \\
\hline $\begin{array}{l}\text { Quality-of-water } \\
\text { analysis }\end{array}$ & R. J. Madison & $\begin{array}{l}\text { Chemical analysis of } \\
\text { water }\end{array}$ & Statewide & $\begin{array}{l}\text { Bureau of Indian Affairs, U.S. Air } \\
\text { Force, U.S. Army, U.S. Public } \\
\text { Health Service, State of Alaska, } \\
\text { Dept. of Environmental } \\
\text { Conservation }\end{array}$ \\
\hline $\begin{array}{l}\text { Surface-water } \\
\text { stations }\end{array}$ & R. D. Lamke & $\begin{array}{l}\text { Monitoring a network of } \\
\text { stream, lake, and } \\
\text { estuary gaging stations }\end{array}$ & Statewide & $\begin{array}{l}\text { Alaska Power Administration, } \\
\text { National Marine Fisheries } \\
\text { Service, U.S. Air Force, U.S. Army } \\
\text { Corps of Engineers, U.S. Forest } \\
\text { Service, State of Alaska, Dept. of } \\
\text { Fish and Game, Dept. of } \\
\text { Highways, Dept. of Natural } \\
\text { Resources }\end{array}$ \\
\hline $\begin{array}{l}\text { Ground-water } \\
\text { stations }\end{array}$ & W. W. Barnwell & $\begin{array}{l}\text { Monitoring a network of } \\
\text { ground-water } \\
\text { observation wells }\end{array}$ & Statewidf & $\begin{array}{l}\text { Kenai Peninsula Borough, State of } \\
\text { Alaska, Dept. of Natural } \\
\text { Resources, Greater Anchorage } \\
\text { Area Borough, U.S. Air Force }\end{array}$ \\
\hline $\begin{array}{l}\text { Hydrological } \\
\text { studies for } \\
\text { Alaskan Air } \\
\text { Command }\end{array}$ & G. A. McCoy & $\begin{array}{l}\text { Limnological } \\
\text { investigations, gas } \\
\text { saturation studies, and } \\
\text { quality of water } \\
\text { resource studies }\end{array}$ & Statewide & $\begin{array}{l}\text { State of Alaska, Dept. of Fish and } \\
\text { Game }\end{array}$ \\
\hline
\end{tabular}

Region: Statewide.

Organizational designation: Water Resources Division, Alaska District Office.

Project chief: G. S. Anderson, U.S. Geological Survey, 1209 Orca Street, Anchorage, Alaska 99501; [907] 279-1563.

Project plans: The objective of this project is to obtain and publish basic data on ground water. Collection of information on ground-water development in Alaska will continue. Work in- cludes aquifer tests and geophysical logging of selected localities.

Cooperating agency: State of Alaska, Division of Geological and Geophysical Surveys.

Project: Quality-of-water stations.

Region: Statewide.

Organizational designation: Water Resources Division, Alaska District Office.

Project chief: R. J. Madison, U.S. Geological 
Survey, 218 E Street, Anchorage, Alaska 99501; [907] 277-5526.

Project plans: The objective of this project is to provide information on physical and chemical properties of water by (1) determining the mineral content and biological aspects of water to establish a base line from which the changes can be evaluated; and (2) determining mineral composition of water to evaluate its use for domestic, municipal, and industrial water supplies. This will be accomplished by operation of a network of water-quality stations.

Cooperating agencies: U.S. Army Corps of Engineers; U.S. Forest Service.

Project: Quality-of-water analysis.

Region: Statewide.

Organizational designation: Water Resources Division, Alaska District Office.

Project chief: R. J. Madison, U.S. Geological Survey, 218 E Street, Anchorage, Alaska 99501 [907] 277-5526.

Project plans: The objective is to make periodic chemical analyses of water collected at Native communities, Air Force sites, and other public water supplies to assess the quality of water and changes in the quality.

Cooperating agencies: Bureau of Indian Affairs; U.S. Air Force; U.S. Army; U.S. Public Health

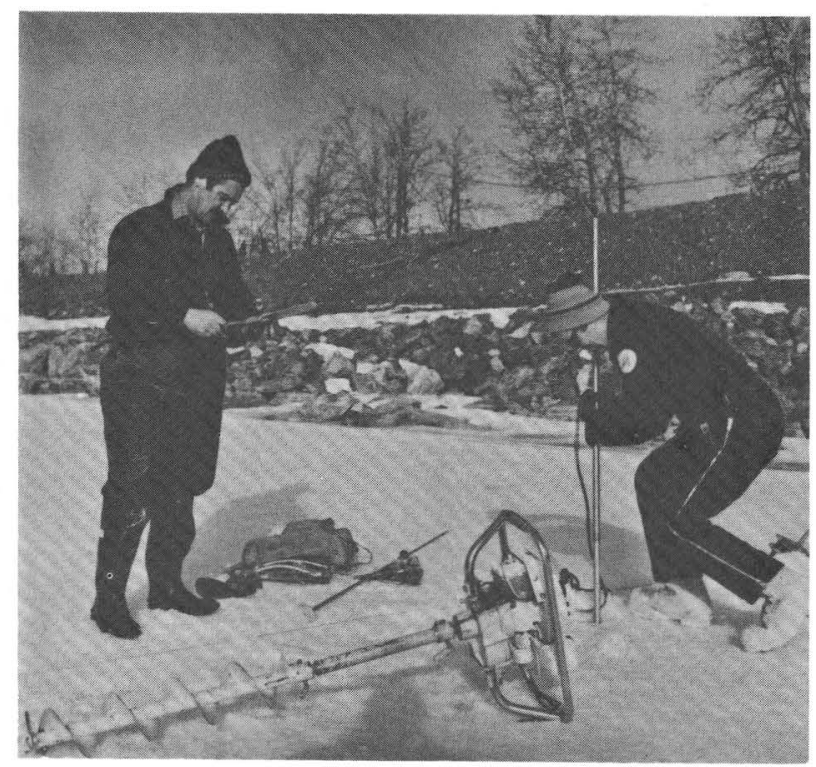

Figure 14.- Stream gaging in Alaska.
Service; and State of Alaska, Department of Environmental Conservation.

Project: Sediment stations.

Region: Statewide.

Organizational designation: Water Resources Division, Alaska District Office.

Project chief: P. J. Still, U.S. Geological Survey, 1209 Orca Street, Anchorage, Alaska 99501; [907] 279-1563.

Project plans: A network of sediment stations is maintained to provide information on sediment in streams, lakes, and estuaries by determining (1) seasonal normal concentrations and particle-size distribution of suspended sediments; (2) sediment yields; (3) particle-size distribution of bed and bank material; (4) bedload transport; and (5) ranges in turbidity.

Cooperating agencies: U.S. Forest Service; U.S Army Corps of Engineers.

Project: Surface-water stations.

Region: Statewide.

Organization designation: Water Resources Division, Alaska District Office.

Project chief: R. D. Lamke, U.S. Geological Survey, 218 E Street, Anchorage, Alaska 99501; [907] 277-5526.

Project plans: The Geological Survey operates a network of complete- and partial-record stations to provide historic and current year data on (1) streamflow, (2) lake stage and contents, and (3) estuary flow conditions. This program is part of an ongoing national assessment of the nation's water resources and is also for use in design and planning of water supply and waste-disposal systems and in the assessment of environmental impacts.

Cooperating agencies: Alaska Power Administration; National Marine Fisheries Service; U.S. Air Force; U.S. Army Corps of Engineers; U.S. Forest Service; State of Alaska, Department of Fish and Game, Department of Highways, and Department of Natural Resources.

Project: Ground-water stations.

Region: Statewide.

Organizational designation: Water Resources Division, Alaska District Office.

Project chief: W. W. Barnwell, U.S. Geological 
Survey, 218 E Street, Anchorage, Alaska 99501 [907] 277-5526.

Project plans: A network of ground-water observation wells is maintained to provide information on water levels throughout Alaska. These wells indicate ground water in storage or in transit, the availability of supplies, show changes in ground-water storage, and are used in estimating base flow of streams. They provide long-term records for basin or watershed studies by means of which shorter records can be correlated.

Cooperating agencies: Kenai Peninsula Borough; State of Alaska, Department of National Resources; Greater Anchorage Area Borough; and U.S. Air Force.

Project: Municipal water-supply investigations.

Region: Statewide.

Organizational designation: Water Resources Division, Alaska District Office.

Project chief: G. S. Anderson, U.S. Geological Survey, 1209 Orca Street, Anchorage, Alaska 99501; [907] 279-1563.

Project plans: The objective of this project is to assess the water resources of small communities in Alaska. Work during 1975 will include continuation of streamflow measurements at Seldovia, Homer, and Cordova. Interpretive geohydrological studies will continue in Cordova and the Pribilof Islands.

Cooperating agencies: State of Alaska, Department of Natural Resources, Division of Geological and Geophysical Surveys, and Division of Lands; City of Cordova; National Oceanic Atmospheric Administration; and National Marine Fisheries Service.

Project: Hydrological studies for Alaskan Air Command.

Region: Statewide.

Organizational designation: Water Resources Division, Alaska District Office.

Project chief: R. J. Madison, U.S. Geological Survey, 218 E Street, Anchorage, Alaska 99501; [907] 277-5526.

Project plans: The objective of this project is to assist the Alaskan Air Command by conducting special hydrological studies on problems relating to their operations in Alaska. Continuing cooperative work with the Alaskan Air Command will include temperature studies of the water in Ship Creek near the powerplant and miscellaneous hydrologic studies as requested.

Cooperating agency: Alaskan Air Command.

Project: Water-quality, water-resources, and limnological investigations at various sites for Alaska Department of Fish and Game.

Region: Statewide.

Organizational designation: Water Resources Division, Alaska District Office.

Project chief: G. A. McCoy, U.S. Geological Survey, 1209 Orca Street, Anchorage, Alaska 99501; [907] 279-1563.

Project plans: The object of this study is to provide basic hydrologic data for use by the Alaska Department of Fish and Game. Limnological investigations of Redoubt, Blue, and Green Lakes near Petersburg will be continued to determine suitability for restocking these lakes with fish. Water quality of the Salcha River near Fairbanks during and after pipeline construction will be monitored. The hydrologic regime of Karluk Lake Basin on Kodiak Island will be described. Gas saturation in hatcheries and fish-rearing sites will be determined. Basic water-quality data on approximately 60 Alaska lakes will be collected to assist in managing the fisheries resources.

Cooperating agency: State of Alaska, Department of Fish and Game.

\section{EAST-CENTRAL ALASKA}

Project: Ground-water studies in the Fairbanks area.

Region and map key: East-central Alaska, metropolitan Fairbanks area (1).

Organizational designation: Water Resources Division, Alaska District Office.

Project chief: J. P. Meckel, U.S. Geological Survey, 310 First Avenue, Fairbanks, Alaska 99701; [907] 452-1951, ext. 176.

Project plans: The purpose of this project is (1) to inventory existing data and collect additional data on wells and springs in the Fairbanks area and (2) to compile and prepare a renort on basic water data in the area.

Cooperating agency: Fairbanks North Star Borough. 


\section{SOUTHERN ALASKA}

Project: Petroleum geology of Cook Inlet Basin. Region and map key: Southern Alaska, parts of Iliamna, Seldovia, Katmai, and Afognak quadrangles (2).

Organizational designation: Geologic Division, Office of Energy Resources, Branch of Oil and Gas Resources.

Project chief: Leslie B. Magoon, U.S. Geological Survey, 345 Middlefield Road, Menlo Park, Calif. 94025; [415] 323-8111, ext. 2116.

Project plans: The onshore and offshore areas from Kalgin Island south to Cape Douglas will be investigated in the following manner. First, up to 500 miles of deep penetration $2,400 \%-$ $4,800 \% \mathrm{CDP}$ and shallow penetration high resolution seismic data will be acquired. Gravity and magnetic data will also be acquired along these lines. Second, geologic field parties will map the Kenai Peninsula around Seldovia and the area from Bruin Bay to Cape Douglas with the express purpose of connecting offshore geophysical data to onshore geology. Stratigraphic sections will be measured, and regional geologic cross sections will be constructed using all this data. This work will include sampling for organic rich rocks capable of generating oil and gas, seals, and reservoir rocks that may be important drilling objectives.

This work will be compiled and distributed in the sections pertaining to the framework geology, petroleum geology, and resource appraisal estimates in the final environmental impact statement for the Lower Cook Inlet sale.

Cooperating agency: State of Alaska, Division of Geological and Geophysical Surveys.

Project: Geohydrology of the Anchorage area, Alaska.

Region and map key: Southern Alaska, Anchorage, Alaska, the Greater Anchorage area extending from Cook Inlet on the west to the crest of the Chugach Mountains and Lake George on the east and from Turnagain Arm on the south to Knik Arm on the north, (3).

Organizational designation: Water Resources Division, Alaska District Office.

Project chief: Chester Zenone, U.S. Geological Survey, 1209 Orca Street, Anchorage, Alaska 99501; [907] 279-1563.

Project plans: The purpose of this project is to monitor the hydrologic impact of urban development and to assess water availability in the Anchorage area. Hydrologic studies include test drilling preparatory to construction of production wells in the Anchorage area, continued study of artificial recharge using infiltration ponds or wells, continued collection of basic data on surface and ground water, continued study of the quality of water underlying sanitary landfill sites, and updating and ut lization of analog and digital models of the Anchorage hydrologic system.

Cooperating agencies: City of Anchorage and the Greater Anchorage Area Borough.

Project: Water-resources investigations of the Kenai Peninsula Borough area, Alaska.

Region and map key: Southern Alasla (4), the Kenai Peninsula Borough.

Organizational designation: Water Resources Division, Alaska District Office.

Project chief: G. S. Anderson, U.S. Geological Survey, 1209 Orca Street, Anchorage, Alaska 99501; [907] 279-1563.

Project plans: The purpose of the project is to monitor the long-term effects of grc rnd-water development by means of measurements of observation wells, stream-gaging stations, and lakes and to continue to inventory industrial and municipal ground-water withdrawals.

In addition, the Geological Survey will cooperate in the continuing test-drilling program to define further the extent of the Beaver Creek aquifer.

Cooperating agencies: City of Kenai and the Kenai Peninsula Borough.

Project: Water-resources investigations of the Valdez-Summit Lake area, south-central Alaska.

Region and map key: Southern Alaska (5).

Organizational designation: Water Resources Division, Alaska District Office.

Project chief: C. E. Sloan, U.S. Geological Survey, 218 E Street, Anchorage, Alaska 9 9501; [907] 277-5526.

Project plans: The purpose of this project is to make a hydrologic appraisal of water availability and quality as related to the industrialization and urbanization activities in and along the trans-Alaska pipeline corridor. During 1975, trips will be made to sample the quality of streams and lakes. An inventory of sources and quality of ground water will also be conducted. Cooperating agency: State of Alaska, Dopartment of Environmental Conservation. 
Project: Hydrology of the Cordova area, Alaska. Region and map key: Southern Alaska (6), Cordova area.

Organizational designation: Water Resources Division, Alaska District Office.

Project chief: G. S. Anderson, U.S. Geological Survey, 1209 Orca Street, Anchorage, Alaska 99501; [907] 279-1563.

Project plans: The purpose of this project is to evaluate the water quality of Eyak Lake and assess water availability in the Cordova area. A digital model of the Cordova water-supply well field has been constructed.

Cooperating agency: City of Cordova.

\section{SOUTHEASTERN ALASKA}

Project: Tracy Arm-Fords Térror Wilderness Study Area.

Region and map key: Southeastern Alaska, parts of Taku River and Sumdum quadrangles (9).

Organizational designation: Geologic Division, Office of Mineral Resources, Wilderness Study Program and Branch of Alaskan Geology.

Project chief: D. A. Brew, U.S. Geological Survey, 345 Middlefield Road, Menlo Park, Calif. 94025; [415] 323-8111, ext. 2178.

Project plans: During late June and most of July, a joint Geological Survey-Bureau of Mines team will complete the field part of the mineral resource potential evaluation of the 1,800 square-mile study area and adjacent "add-on" areas. The evaluation, which was started in 1973, includes reconnaissance geologic mapping, intensive geochemical sampling of bedrock and stream sediments, mapping and sampling of known prospects, aeromagnetic mapping, analysis of the results of these efforts, and preparation of a report of the findings. The evaluation is part of the U.S. Forest Service study of the suitability of the project area for classification in the National Wilderness System established by the Wilderness Act of 1964 .

The team will include D. A. Brew, A. B. Ford, D. Grybeck, and one other geologist, together with assistants C. J. Nutt and C. Carlson from the Geological Survey and A. L. Kimball and J. Still, mining engineers, assistant J. Ratté and one other assistant from the Bureau of Mines. The work will be based on the U.S.G.S. R/V Don $J$. Miller $I I$ and will be supported by contract helicopter.
Radio contact will be through Juneau Marine radiotelephone operator to the Don J. Miller, call letters WZ 2103. The mailing address will be: U.S. Geological Survey, \% Channel Flying, Inc., R. R. 3, Box 3577, Juneau, Alaska 99801. Cooperating agen $y$ : U.S. Bureau of Mines.

Project: Water resources of the City and Borough of Juneau, Alaska.

Region and map key: Southeastern Alaska (8), Juneau, Alaska.

Organizational designation: Water Resources Division, Alaska District Office.

Project chief: G. O. Balding, U.S. Geological Survey, 441 Federal Building, 710 West 9th Street, P.O. Box 1568, Juneau, Alaska 99802; [907] 586-7216.

Project plans: The purpose of this project is to evaluate the water resources of the Juneau area with special emphasis on the Mendenhall Valley. Test drilling will be continued to assess the reported high potential yield of ground water.

Cooperating agencies: City and Borough of Juneau, Alaska.

Project: Glacier Bay National Monument Wilderness Study Area.

Region and map key: Southeastern Alaska, parts of Skagway, Mount Fairweather, and Juneau quadrangles (7).

Organizational designation: Geologic Division, Office of Mineral Resources, Wilderness Study Program and Branch of Alaska Geolngy.

Project chief: D. A. Brew, U.S. Geological Survey, 345 Middlefield Road, Menlo Park, Calif. 94025; [415] 323-8111, ext. 2178.

Project plans: During late July and the first part of August, a joint Geological Survey-Bureau of Mines team will start a mineral resource potential evaluation of the 3,910 sxuare-mile National Monument. The field studies will continue in the summers of 1976 ard 1977. In addition to verifying and updating data gathered by the Geological Survey in 1966 (published as U.S. Geological Survey Professional Paper 632) the evaluation includes further reconnaissance geologic mapping, intensive geochemical sampling of bedrock and stream sediments, mapping and sampling of known prospects, aeromagnetic mapping, analysis of the results of these efforts, and preparation of a report of the findings. The 


\begin{tabular}{|c|c|c|c|c|}
\hline Name of project & Project chief & Type of work & Area(s) & Cooperating agencies \\
\hline $\begin{array}{l}\text { Ground-water } \\
\text { studies in the } \\
\text { Fairbanks area }\end{array}$ & J. P. Meckel & $\begin{array}{l}\text { Inventory, compile, and } \\
\text { t tabulate data on } \\
\text { ground-water, various } \\
\text { hydrologic studies }\end{array}$ & Fairbanks area & Fairbanks North Star Borough \\
\hline $\begin{array}{l}\text { Petroleum geology } \\
\text { of Cook Inlet } \\
\text { basin }\end{array}$ & $\begin{array}{l}\text { L. B. Magoon, W. L. } \\
\text { Adkison, M. A. } \\
\text { Fisher }\end{array}$ & $\begin{array}{l}\text { Geologic framework using } \\
\text { geophysics and geology }\end{array}$ & $\begin{array}{l}\text { Parts of } \\
\text { Iliamna, } \\
\text { Seldovia, } \\
\text { Katmai, and } \\
\text { Afognak } \\
\text { quadrangles }\end{array}$ & $\begin{array}{l}\text { State of Alaska, Division of } \\
\text { Geological and Geophysical } \\
\text { Surveys }\end{array}$ \\
\hline $\begin{array}{l}\text { Geohydrology of the } \\
\text { Anchorage area, } \\
\text { Alaska }\end{array}$ & Chester Zenone & $\begin{array}{l}\text { Test drilling, various } \\
\text { hydrologic studies }\end{array}$ & Anchorage area & $\begin{array}{l}\text { City of Anchorage and the Greater } \\
\text { Anchorage Area Borough }\end{array}$ \\
\hline $\begin{array}{l}\text { Water-resources } \\
\text { investigations of } \\
\text { the Kenai } \\
\text { Peninsula } \\
\text { Borough area, } \\
\text { Alaska }\end{array}$ & G. S. Anderson & $\begin{array}{l}\text { Monitoring observation } \\
\text { wells, stream-gaging } \\
\text { stations and lakes, } \\
\text { geohydrologic studies }\end{array}$ & $\begin{array}{l}\text { Kenai Peninsula } \\
\text { Borough }\end{array}$ & $\begin{array}{l}\text { City of Kenai and the Kenai } \\
\text { Peninsula Borough }\end{array}$ \\
\hline $\begin{array}{l}\text { Watè-resources } \\
\text { investigations of } \\
\text { the Copper } \\
\text { Center-Summit } \\
\text { Lake area, } \\
\text { south-central } \\
\text { Alaska }\end{array}$ & C. E. Sloan & $\begin{array}{l}\text { Water-quality sampling, } \\
\text { ground-water } \\
\text { inventorying, } \\
\text { geohydrologic studies }\end{array}$ & $\begin{array}{l}\text { Copper Center } \\
\text { area }\end{array}$ & $\begin{array}{l}\text { State of Alaska, Department of } \\
\text { Environmental Conservation }\end{array}$ \\
\hline $\begin{array}{l}\text { Hydrology of the } \\
\text { Cordova area, } \\
\text { Alaska }\end{array}$ & G. S. Anderson & $\begin{array}{l}\text { Water-quality } \\
\text { studies, } \\
\text { geohydrologic } \\
\text { studies }\end{array}$ & $\begin{array}{l}\text { Cordova, Eyak } \\
\text { Lake }\end{array}$ & City of Cordova \\
\hline $\begin{array}{l}\text { Tracy Arm-Fords } \\
\text { Terror } \\
\text { Wilderness Study } \\
\text { Area }\end{array}$ & $\begin{array}{l}\text { D. A. Brew, A. B. } \\
\text { Ford, D. Grybeck, } \\
\text { C. J. Nutt, C. } \\
\text { Carlson, A. L. } \\
\text { Kimball, J. Still, } \\
\text { J. Ratté }\end{array}$ & $\begin{array}{l}\text { Geologic mapping, } \\
\text { geochemical } \\
\text { sampling, } \\
\text { aero-magnetic } \\
\text { mapping }\end{array}$ & $\begin{array}{l}\text { Parts of Taku } \\
\text { River } \\
\text { and Sumdum } \\
\text { quadrangles }\end{array}$ & U.S. Bureau of Mines \\
\hline $\begin{array}{l}\text { Water resources } \\
\text { City and Borough } \\
\text { of Juneau }\end{array}$ & G. O. Balding & $\begin{array}{l}\text { Water-resources } \\
\text { data compilation, } \\
\text { aquifer tests }\end{array}$ & Juneau area & City and Borough of June`u \\
\hline $\begin{array}{l}\text { Glacier Bay } \\
\text { National } \\
\text { Monument } \\
\text { Wilderness Study } \\
\text { Area }\end{array}$ & $\begin{array}{l}\text { D. A. Brew, A. T. } \\
\text { Ovenshine, D. } \\
\text { Grybeck, C. J. } \\
\text { Nutt, C. Carlson, } \\
\text { A. L. Kimball, J. } \\
\text { Still, J. Ratté, R. } \\
\text { A. Loney, G. A. } \\
\text { Himmelberg }\end{array}$ & $\begin{array}{l}\text { Geologic mapping, } \\
\text { geochemical sampling, } \\
\text { aero-magnetic mapping }\end{array}$ & $\begin{array}{l}\text { Parts of Skagway, } \\
\text { Mt. } \\
\text { Fairweather, } \\
\text { and Juneau } \\
\text { quadrangles }\end{array}$ & U.S. Bureau of Mines \\
\hline
\end{tabular}

evaluation is part of the U.S. National Park Service study of the suitability of the project area for classfication in the National Wilderness
System established by the Wildernes' Act of 1964.

The team will include D. A. Brew, A. T. 
Ovenshine, D. Grybeck, and one other geologist, together with assistants C. J. Nutt and C. Carlson from the Geological Survey and A. L. Kimball and J. Still, mining engineers, assistant J. Ratté and one other from the Bureau of Mines. R. A. Loney and G. A. Himmelberg of the Geological Survey will join the party for specific studies during part of the time. The work will be based on the U.S.G.S. R/V Don J. Miller II and will be supported by contract helicopter.

Radio contact will be through Juneau Marine radiotelephone operator to the Don J. Miller, call letters WZ 2103. The mailing address will be: U.S. Geological Survey, \% Channel Flying, Inc., R. R. 3, Box 3577, Juneau, Alaska 99801. Cooperating agency: U.S. Bureau of Mines.

\section{SUMMARY OF IMPORTANT RESULTS, 1974}

The Geological Survey prepares annual summaries of the principal technical results of its investigations, and about a year after preparation these summaries are published in the Professional Paper series under the title, "Geological Survey Research." Many of the summaries appearing in this section are taken from the material prepared for the coming Professional Paper. Some are original for this publication.

Significant new scientific and economic geologic information has resulted from many field and topical investigations in Alaska during the past year. Discussions of the findings are grouped under seven subdivisions corresponding to six major geographic regions and a general, statewide category. Locations of the study areas are shown in the accompanying index map of Alaska (fig. 15).

\section{STATEWIDE}

New geological map of Alaska

by Helen M. Beikman

A new geologic map of Alaska at a scale of $1: 2,500,000$ ( 1 inch equals about 40 miles), which will supersede the map previously published in 1957 , is being prepared by Helen M. Beikman. The map will be an entirely new compilation that will synthesize and summarize all available data from Federal, State, and other agencies. Uncolored geologic maps at a scale of $1: 1,000,000$, which are preliminary compilations upon which the final multicolor map will be based, are being published as soon as they are completed. Interim maps at this scale thus far have been published as MF-611, covering the southwestern part of the State, and MF-612, covering the south-central part. Interim maps of the Alaska Peninsula-Aleutian Islands and of the southeastern panhandle are completed and will be published during 1975. Compilation of the geology of the northern part of the State is now in progress. It is anticipated that a preliminary compilation of the entire State at 1:2,000,000 will be completed during 1975 .

\section{Mineral resources of Alaska}

By Edward H. Cobb

Products of this office project during 1974 comprised a short synopsis of the mineral resources and geology of Alaska (Cobb; 1974a); lists of Federal and State and Territory of Alaska reports and maps on the geology and mineral resources of Alaska from 1884 through 1973, indexed by topographic mapping quadrangles (scale 1:250,000) (Cobb, 1974b-i); and an index of metallic mineral deposits of Alaska (Cobb, 1974j).

Progress toward a metamorphic facies map of Alaska By David A. Brew

A Branch of Alaskan Geology committee (D. A. Brew, B. Csejtey, A. B. Ford, H. L. Foster, T. P. Miller, and H. N. Reiser) is compiling a $1: 2,500,000$-scale metamorphic facies map of Alaska from existing information and from current Alaskan Branch field studies. Metamorphic mineral locality information is being collected in machine-processable form and will be available for retrieval according to several criteria. The map is intended as a contribution to (1) a Map of the Metamorphic Belts of the World sponsored by the Commission for the Geological Map of the World of the International Geological Congress and the International Union of Geological Sciences, and to (2) the joint U.S. Geological Survey-State of Alaska Division of Geological and Geophysical Surveys publication on the Geology cf Alaska. The map shows metamorphic facies, facies groups, facies series, selected isograds, and granitic rock bodies in the style of the IUGS suggested metamorphic facies map explanation (1967). Preliminary compilation of regional metamorphic facies maps at 1:1,000,000 scale is essentially complete for the state, as is coding of background metamorphic mineral locality information. The $1: 1,000,000$ regional maps are being combined. 

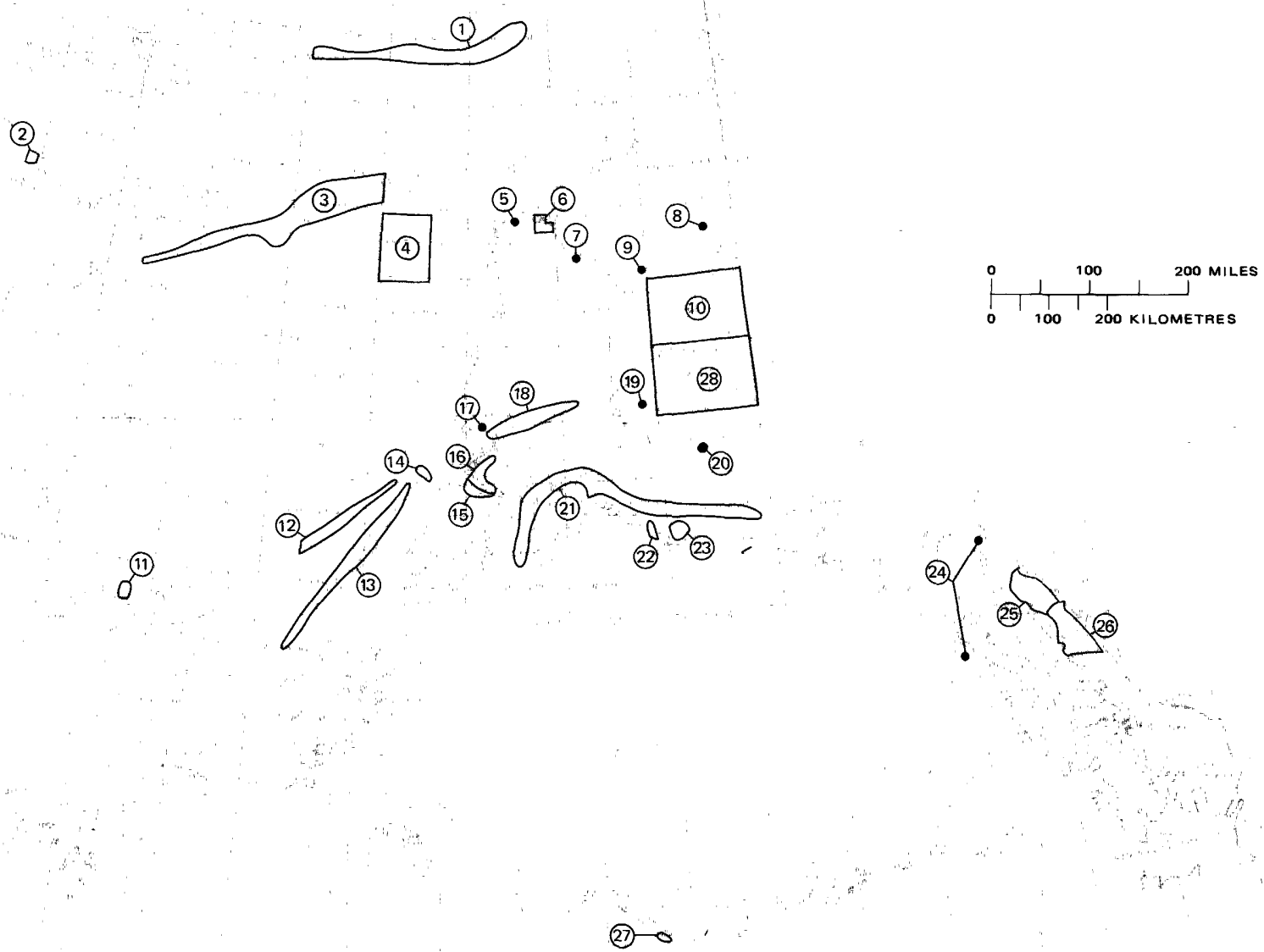

Figure 15.-Locations of studies discussed in the summary of important results, 1974 . The circled numbers key to project discussions in text. 
Tectonic significance of giant linears in Alaska By E. H. Lathram and N. R. D. Albert

Preliminary analysis of space image linears in northern and central Alaska by E. H. Lathram and N. R. D. Albert (1975) indicates that many reflect subsurface geologic structures of varying ages, some quite old. The correlation of geology, geophysics, and possibly metallogenic terranes with giant linears $(>1,000 \mathrm{~km}$ long), coupled with the existence of definite sets having nearly orthogonal trends suggests that giant linears indicate more fundamental structures than do shorter ones. The trends of giant linears correspond closely with trends of Precambrian, early and late Paleozoic, and Mesozoic orogenic belts in northern and central Alaska as described by Brosgé and Dutro (1973) and Lathram (1973). Grantz (1966, p. 72) suggested that a conjugate system of faults or lineaments may lie within the crust of Alaska, disguised by Mesozoic and Cenozoic formations, along which large blocks have moved differentially, a conclusion later shared by Churkin (1973) and Lathram (1973). The giant linears seem to mark the sites of such major, old crustal fractures or structures. The giant linears may be related to a global "regmatic shear pattern," but since several northeast- and northwest-trending nearly orthogonal sets of giant linears are present, the relationship is not a simple one.

Preliminary analysis of an ERTS mosaic of the western conterminous states revealed a number of giant linears similar to those in Alaska. These linears have trends near the azimuth of both the Alaskan linears and the partially concealed structures of Precambian age that transect the Cordillera in Alberta, British Columbia, and the Yukon Territory (Sikabonyi and Rodgers, 1959; Haites, 1960), many of which are marked by physiographic linears (Haites, 1960) that would appear on ERTS imagery. They are also similar in trend to linears described by Thomas (1974) in Montana, Wyoming, and Colorado, which he believes are basement weakness zones along which transcurrent movement has occurred.

The occurrence of giant linears of similar nature and trend throughout the North American Cordillera suggest that they reflect fundamental crustal structures that are not peculiar to Alaska. Many of these linears traverse postulated continental and oceanic crustal areas of various ages, transecting the supposed boundaries with little or no deviation. If these linears do reflect very old or crustal structures, these structures have apparently been unperturbed by plate tectonic movement. Clearly, an understanding of the origin and age of these linears is significant in un lerstanding the tectonic history of Alaska, and cf the North American Cordillera, and in develcning viable tectonic hypotheses that explain features of the formational and deformational histcry of continental blocks.

\section{Alaska geothermal study}

By Thomas P. Miller and Robert L. Smith

Studies were begun on the Quaternary volcanic centers on the tip of the Alaska Penirsula and on Unimak Island in the eastern Aleutian Islands. Reconnaissance mapping and samplirg of most of the calderas between Cold Bay and Katmai National Monument was essentially completed during 1974. Particular attention has been given to the distribution, composition, and age of the ash flows surrounding the calderas, along with studies of the nature of postcaldera volcarism. These studies together with ongoing laboratory investigations should provide a basis for evaluating the geothermal potential of these young volcanic centers.

Fieldwork in the Mount Drum area (loc. 19)of the western Wrangell Mountains was completed by D. H. Richter, R. L. Smith, and T. F. Miller and an extensive sampling program for: K/Ar age dating of critical samples will help provide a unique understanding of this volce no and its potential for geothermal energy.

Hydrological studies for Alaskan Air Commard

By R. J. Madison

A report on the water supply potential at Murphy Dome (loc. 5) based on geophysical techniques (magnetic, seismic, and resistency) is in preparation. A proposed well location near the present production well offers the highest potential for future expansion.

Hydrologic environment of the Trans-Alaska P: meline System (TAPS) Alaska

By J. M. Childers

Channel surveys at 26 sites in Alaska along TAPS route were used to measure erosion and causative factors. Vertical aerial stereophotography at the sites was compared with rreconstruction photography to assess changes caused by the 


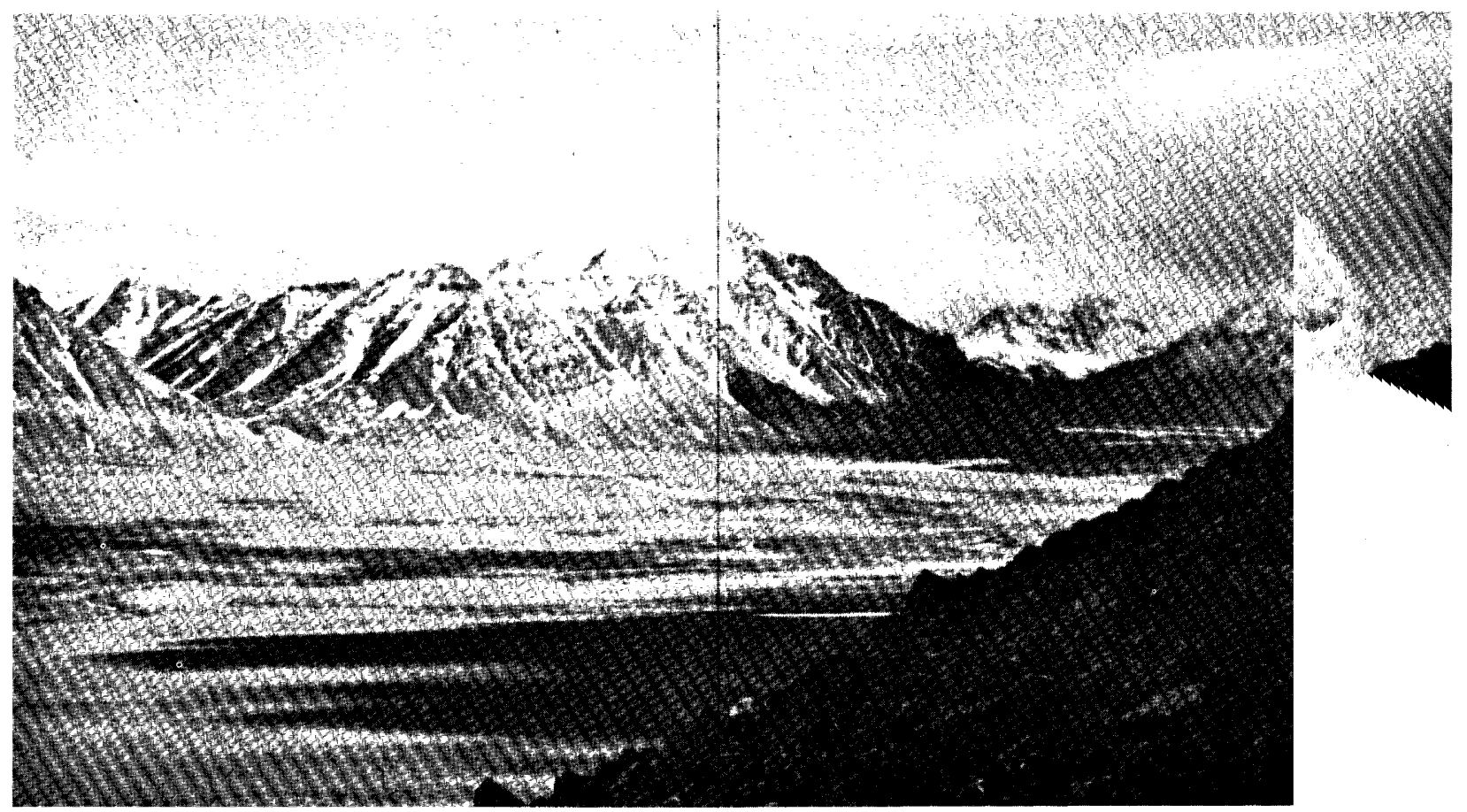

FIgURE 16.-Valley of the Anaktuvuk River looking southwest to Anaktuvuk Pass.

construction of camp pads, airstrips, and the Kamikaze haul road to Prudhoe Bay. This work is part of a continuing study of the interactions of floods, ice, and construction on the stream channels along TAPS route.

Preconstruction base line biological water quality of the Chena and Little Chena Rivers, or water quality of a subarctic stream system

By G. A. McCoy

Water-quality studies of the Chena and Little Chena Rivers indicate that the streams are clean and have high dissolved oxygen content. Iron content increases downstream. Fauna and flora are diverse. The study provides a base line for noting changes during or after construction of the Moose Creek and Little Chena dams.

\section{NORTHERN ALASKA}

Metamorphic belts in the southern Brooks Range By W. P. Brosgé

Previous work has shown that garnet and amphibole rocks, including both blueschist and amphibolite, occur in a zone about $10 \mathrm{~km}$ wide within the pelitic schists that form the south edge of the Brooks Range in the southeast part of Ambler River quadrangle (Forbes and others,
1971; Pessel and others, 1973). Petrographic data from collections by the Alaska Division of Geological and Geophysical Surveys and the U.S. Geological Survey have recently been compiled by W. P. Brosgé, H. N. Reiser, I. L. Tailleur, R. B. Forbes, and C. F. Mayfield, and by G. H. Pessel of the Alaska Division of Geological and Geophysical Surveys, for the adjacent Survey Pass, Wiseman, and Chandalar quadrangles to be used in preparing a small-scale metamorphic facies map of Alaska. These data show that within the schists of lower greenschist facies which characterize most of the southern Brooks Range, a zone of garnetbearing schist extends eastward almost continuously for about $340 \mathrm{~km}$ from the southeast Ambler River quadrangle to the northeast part of Chandalar quadrangle (loc. 1). The present width of this garnet zone is about $5-15 \mathrm{~km}$, but it may originally have been wider; helycitic garnets completely retrograded to chlorite occur locally in lower greenschist facies rocks about $4 \mathrm{~km}$ south of the garnet zone in central Wiseman quac'rangle. In the western $150 \mathrm{~km}$ of this zone chlcritoid and biotite are also common, and glaucophane was found every 15 or $30 \mathrm{~km}$ in samples from metasedimentary as well as mafic rocks. Kyanite occurs east of the last known glaucophane locality, 
in samples from eastern Survey Pass and western Wiseman quadrangles. In most of the Wiseman and Chandalar quadrangles, glaucophane and kyanite are absent in the garnet zone, chloritoid is rare, and biotite is common, but at the east end of the zone in the Chandalar quadrangle, glaucophane occurs again as almost completely chloritized relics in retrograded amphibole schist. Elsewhere in the zone the glaucophane is fresh to partly chloritized.

Granitic plutons crop out a few $\mathrm{km}$ north of the zone in Survey Pass quadrangle, where the partially altered glaucophane and garnet and local biotite in the west half of the zone indicate a thermal overprint on an earlier high-pressure assemblage as previously described in the southeast Ambler River quadrangle (Alaska Division of Geological and Geophysical Surveys, 1973). Granitic plutons lie within the zone in Chandalar quadrangle, and the garnet-biotite assemblage in Wiseman and Chandalar quadrangles indicates that most of the east half of the zone is the product of low-pressure thermal metamorphism. However, the rare occurrence of almost completely altered glaucophane and garnet near the granite at the east end of the zone suggests that the highpressure assemblage may originally have extended throughout the zone. In any case it seems that a long narrow zone of thermal metamorphism either coincided with or was in linear continuity with a long narrow zone of high-pressure metamorphism.

\section{EAST-CENTRAL ALASKA}

Geology of western half of the Kantishna River quadrangle By Robert M. Chapman

Bedrock and unconsolidated deposits were mapped in the western half of the Kantishna River quadrangle (loc. 4) by R. M. Chapman, W. W. Patton, Jr., and W. E. Yeend during 10 days of helicopter-supported reconnaissance in July 1974. Some of this area was mapped in 1915 by H. M. Eakin (1918), and parts of it were previously unmapped. A better geologic map of this area will be compiled from the information gathered in 1974, but owing to relatively few exposures, accessibility problems, extensive vegetation cover, and insufficient time for detailed mapping, the following geologic interpretations are tentative.

Seven major bedrock units are distinguished, ranging in age from early Paleozoic to Tertiary.
The apparently oldest unit is quartzite, metasiltstone, and phyllite, probably of Ordovician or older age, that lies in the Bitzshtini Mountains and extends southwest to Haystack I Tountain. A unit of chert and slate forms the northern end of the Kuskokwim Mountains between the head of the Zitziana River and Lake Minchumina, and is tentatively correlated with similar chert units in the Dugan Hills and Livengood quadrangle that recently have been identified as Ordovician. A unit of chloritic calcareous schist, mafic rocks, and some limestone forms the hills at the heads of the Big Mud and Chitanana Rivers and north of the Titna River. The age of this unit is uncertain but probably is Ordovician, Silurian, or Devonian. A sparsely-fossiliferous limestone and dolomite unit, which for $\mathrm{ns}$ a southwest-trending bel ${ }^{+}$of semibarren, light-colored hills between the Redlands Lake area and Sischu Mountain, is Dovonian, or possibly Silurian and Devonian, in age, and may be correlative with the Tolovana Limestone. A unit of graywacke, siltstone, and shale forms the low hills between Bitzshtini and Chitanatala Mountains. These rocks strongly resemble those of Jurassic(?) and Cretaceous age in the Tanana and Livengood quadrangles.

A unit of mafic rocks, chiefly diabas? and basalt, forms the highest part of the Chitanatala Mountains and a southwest-trending belt of hills 4-7 miles north of Sischu Mountain. ".?his unit is apparently of Mesozoic age, or might be in part correlative with the Permian(?) Rampart Group. Granitic and monzonitic rocks form part of the hills between Redlands Lake and the Cosna River, and crop out on two hills on the upper Chitanana River. Similar rocks form the top of Haystack Mountain and a large part of Sischu Mountain. These rocks are probably of Late Cretaceous or early Tertiary age. Rhyolitic and tuffaceous rocks, which appear to cap the hills, extend southwest from the Chitanatala Mountains to tl o south side of Sischu Mountain. These rocks are apparently the youngest in the area and presumably are of Tertiary age.

Several units of unconsolidated deposits are differentiated from field observations and aerial photograph interpretation. A large part of the area west of the Cosna River and north of the Chitanana River is covered by an eolian sand and silt unit that is characterized by east-northeast trending elongate dunes, which are stabilized by vegetation. A bedded clay, silt, sand, and gravel 
unit of apparent lacustrine origin covers a large portion of the lowlands along the middle and upper portions of the Chitanana River. A silty unit, consisting of loess and solifluction mantle material, is widespread in the southern two-thirds of the area and occurs largely below altitudes of 1,200 feet. Recent and older alluvium deposits are significantly large only along the largest streams.

Environmental geology and land utilization of the Fairbanks area, Alaska

By Troy L. Péwé

New geologic maps and derivative environmental maps for land use planning on the scale of 1:24,000 were completed for the Fairbanks area in 1974. Field data obtained in 1972, plus information from earlier surveys, were compiled and interpreted by Troy L. Péwé and John W. Bell to produce geology, permafrost, construction materials, foundation conditions, and ground-water maps of the Fairbanks D2-SW, D2-NW, D2-SE, D2-NE, and D1-SW quadrangles covering the Fairbanks area (loc. 6), a total of 25 maps. Robert B. Forbes and Florence R. Weber were consulted on the pre-Cenozoic geology on the D2 geologic maps.

The five geologic maps (in press) are colored maps of the Miscellaneous Geologic Investigation Series. The D2-SW is number 829-A, D2-NW is 907, and D2-NE, D2-SE, and D1-SW have not been assigned numbers as yet. The set of environmental maps for the D2-SW quadrangle is also in color and is in press as Permafrost Map 829-B, Construction Materials Map 829-C, Foundation Conditions Map 829-D, and Ground-Water Map 829-E.

The 16 other environmental geology maps describe distribution, thickness, and character of permafrost; location of ground-water resources; location of construction materials; and types of foundation problems. They are completed and assigned to the Miscellaneous Field Maps Series; they are in press to be published without color.

New Pleistocene vertebrate fossil site in the Big Delta quadrangle

By F. R. Weber

Vertebrate fossils were discovered on Canyon Creek (loc. 7), in the Big Delta quadrangle, $105 \mathrm{~km}$. southeast of Fairbanks, Alaska, in 1974 by Florence Weber. The locality was also later examined by D. M. Hopkins, and T. D. Hamilton.
Bones of a small horse, Camelops, bism, mammoth, Saiga, wolf, rabbit, and caribou(?) from the same stream channel fill were idertified by Charles Repenning. Although remains of these animals are common in Alaskan P'eistocene deposits, they are seldom found in stretigraphic context and this may be the first authentic association of Camelops, an extinct Nor ${ }^{+} h$ American camel, with Saiga, an extant Asiatic antelope. This association suggests a mixing of major faunal types across the Bering Straits lant bridge, probably in late Pleistocene time.

The fossil-bearing gravels are overlain unconformably by approximately $15 \mathrm{~m}$ of eolian sand and silt. Some of the overlying material is ventifact-bearing colluvium marked ly rodent burrows and fossil ice wedges. An organic horizon in the eolian deposits $5 \mathrm{~m}$ above the unconformity has given a $\mathrm{C}^{14}$ date of approximately 9500 b.p. (before present) but no suitable dating material has been found associated with the bones.

Metamorphosed peridotite in the Big Delta A-1 quadrangle By Helen L. Foster

Several small metamorphosed peridotite bodies were found during the course of reconnaissance geologic mapping in the Big Delta A-1 quadrangle (loc. 9). The ultramafic rock is foliated and folded and has been subjected to the same regional metamorphism as the surrounding country rock. The ultramafic rocks appear to have $\varepsilon$ different history than those recently described in the Eagle quadrangle, except for one similar body south of Mt. Harper in the Eagle A-6 quadrangle.

The several separate small bodies may have been part of one or more larger bodies which have been tectonically broken up and separated.

Significant platinum values confirmed in ultramaf rock of the Eagle C-3 quadrangle

By Helen L. Foster

A small ultramafic body in the Eagle C-3 quadrangle (loc. 8) yielded a significant value for platinum group metals from two samples that were collected in 1969 and analyzed in 1973 (Keith and Foster, 1973, sample No. 69AFr748B). This was the only ultramafic body in the Eagle quadrangle yielding values above $0.03 \mathrm{ppm} \mathrm{Pt}$. (Rocks from 32 different bodies were analyzed for platinum group metals.) In the summer of 1974 , more material was collected from this body and 12 additional analyses made. One specimen yielded 3 
ppm Pt and $1.5 \mathrm{ppm} \mathrm{Pd}$, and $0.030 \mathrm{ppm} \mathrm{Rh}$. Other specimens in the group gave values ranging from not detected to $0.200 \mathrm{ppm} \mathrm{Pt}$ and not detected to 0.015 ppm Pd.

\section{WEST-CENTRAL ALASKA}

Holocene glaciation in the Kigluaik Mountains, Seward Peninsula

By R. E. Nelson

Field studies conducted during August of 1974 in the Grand Central River Valley (loc. 2) by R. E. Nelson, assisted by M. L. Throckmorton, provide geomorphic evidence that indicates the Mount Osborn Glaciation may be of Neoglacial age. Field mapping of the maximum extent of glacial ice of Mount Osborn age, and of a subhistoric advance of the past few centuries, has been completed for the valley. This is the first such mapping of Holocene glaciations in western Alaska.

Tentative correlations have been drawn between the Mount Osborn Glaciation and the Alapah Mountain Glaciation of the Brooks Range, and between the subhistoric advance in the Kigluaik Mountains and the Fan Mountain Glaciation of the Brooks Range.

Studies of the altitudes of cirque floors in the Kigluaik Mountains, utilizing aerial photographs, topographic maps, and field data, indicate that modern snowline lies at or above $660 \mathrm{~m}$ elevation. A net lowering of snowline of $75 \mathrm{~m}$ resulted in the subhistoric advance, while the Mount Osborn advance was accompanied by a snowline depression of $150 \mathrm{~m}$. Preliminary results indicate that Wisconsin snowline probably lay at about $360 \mathrm{~m}$ elevation, or $300 \mathrm{~m}$ below modern snowline, in the Kigluaik Mountains and vicinity.

\section{New information on the Kaltag fault} By William W. Patton, Jr.

Ground and aerial inspection of the Kaltag fault between Tanana and Unalakleet (loc. 3) was carried out by W. W. Patton, Jr., R. M. Chapman, George Plafker, and Warren Yeend in August 1974. No fresh breaks or other evidences of modern activity were found along this part of the fault. However, offset streams, ponded drainages, and slice and shutter ridges of bedrock and gravel along the fault zone attest to significant movement in late Cenozoic time. Tilted nonmarine coalbearing deposits of probable late Tertiary age were observed at three localities within the fault zone.
In the Melozitna quadrangle "blue-schist facies" rocks were discovered in Precamlrian(?) and Paleozoic metamorphic assemblages north of the fault. These blue amphibole-bearing rocks appear to represent the offset extension of the "blue-schist facies" terrane in the Kaiyuh Hills (Forbes and others, 1971) and provide additional support for previously published estimates (Patton and Hoare, 1968) of about $140 \mathrm{~km}$ of right-lateral offset along this segment of the Kaltag since. Cretaceous.

\section{SOUTHWESTERN ALASKA}

Lower Cretaceous rocks and tectonic activity north of Bristol Bay

By J. M. Hoare, W. L. Coonrad, R. L. Dettermar, and D. L. Jones

An unusually interesting section of sedimentary rocks of Cretaceous age was found between the Ungalikthluk and Kulukak Rivers in the Goodnews Bay quadrangle (loc. 11) in t]e 1974 field season. On the geologic map of the Goodnews Bay quadrangle (Hoare and Coonrad, 19:1) the rocks were assigned a Late Cretaceous age. But new fossil collections show that they were deposited in Early Cretaceous (Valanginian and Hauterivian) time.

The section is at least $2,500 \mathrm{~m}(7,500$ feet $)$ thick and may be as much as $3,500 \mathrm{~m}$ (10,500 feet) thick. The rocks are only mildly deformed. Except for minor irregularities, they strike N. $40^{\circ}$ E. and dip consistently southeastward. They prc bably are the least deformed thick section of Lower Cretaceous rocks in southwest Alaska. They are overlain to the east by volcanic rocks of Early Jurassic age which have been thrust northwestward on the Kulukak fault. The fault trends about N. $25^{\circ} \mathrm{E}$. along the east wall of the Kulukak valley.

The Lower Cretaceous rocks occur in an area of about $325 \mathrm{~km}^{2}$ between the Kulukak and Ungalikthluk faults and are surrounded by older, chiefly volcanic, rocks of Early Jurassic age. The isolated occurrence, thickness, and their relative susceptibility to erosion suggest that the Lower Cretaceous rocks were preserved beneath a thrust, sheet which was transported northwestward on the Kulukak fault in post-Early Cretaceous time.

The Lower Cretaceous strata include lithologically distinct coeval facies that must have been deposited some distance apart. However, the coeval facies now form converging belts of outcrop $1.5-5 \mathrm{~km}$ apart on either side of the Buchia Ridge fault. They must have been telescoped at least a few kilometres by northwest transport. 
Volcanic rocks of Early Jurassic age are locally metamorphosed to phyllite and schist in the vicinity of faults. The Lower Cretaceous rocks contain clasts of these metamorphosed rocks. This, and the lack of Upper Jurassic rocks, indicates that the area north of Bristol Bay was emergent and tectonically active in Late Jurassic time.

Thus the Lower Cretaceous rocks not only provide evidence for two periods of tectonic activity but they also suggest that the style of deformation in Mesozoic time included low angle thrust faults.

Bathymetry of Cannikin Lake, Amchitka Island, Alaska, with an evaluation of computer-mapping techniques

By Diego Gonzalez, Leonard E. Wollitz, and G. E. Brethauer

A bathymetric map, the basic geometry of Cannikin Lake (loc. 27), and the stage-areavolume relationship were derived from data produced by a sonic survey of the lake (Gonzalez and others, 1974). This was done as part of a study to define the characteristics of the lake to determine the effect of a subsurface nuclear detonation on the hydrologic and biologic environment. At the lake's highest level, the maximum depth is 31 feet $(9.45 \mathrm{~m})$, it has a volume of 325 acre-feet $\left(401 \times 10^{3} \mathrm{~m}^{3}\right)$ and covers a surface area of 30 acres (12.1 hectares). A computermapping technique utilizing two different computer programs (WET and Calcomp GPCP) was used to evaluate the usefulness of the programs as mapping tools. The two bathymetric maps of the lake bottom produced by this method show a high degree of reliability when compared with the hand-drawn version.

Energy resources beneath the Bering Sea shelf

By M. S. Marlow, D. W. Scholl, A. K. Cooper, and E. C. Buffington

Reconnaissance geologic surveys of the eastern Bering Sea margin have revealed 14 geologic basins and three geologic ridges beneath the shelf. The Mesozoic foldbelt of southern Alaska has been traced from the Alaska Peninsula through the shelf to eastern Siberia. Beneath the shelf, two of the largest basins, Navarin and St. George, contain an estimated $8-10 \mathrm{~km}$ of Late Cretaceous(?) and Cenozoic strata. The basin fill is extensionally deformed along the flanks of these grabens and half grabens by high-angle normal, "growth-type" faults. Within the sedimentary section there is a divergence or disconformity of probable Miocene age. This basinwart-dipping divergence may represent a major change in sedimentation rates over the shelf as a result of a change in the drainage of the Yukon River from the Pacific to the Bering Sea. The basin fill and the thick sedimentary section beneath the shelf are immediate petroleum prospects.

Bright spots and magnetic lineations in the Berin r Sea basin By M. S. Marlow, D. W. Scholl, A. K. Cooper, and E. C. Buffington

A study of seismic reflection records collected by the U.S. Naval Oceanographic Office revealed a number of strong reflectors or "bright spots" within the sedimentary section of the northern Aleutian Basin. Beneath these spots of brightness there are anomalous, deformed structur?s. While in deep water, these structures may be indicative of significant hydrocarbon deposits. Alan K. Cooper assembled all of the magnetic data in the deep Bering Sea Basin as part of a doctorsl study at Stanford University. His study revealed a series of north-south, oceanic-type magnetic anomalies. These anomalies have been provisionally dated as 117 to 132 m.y. in age; the crust from which the anomalies originate is thought to be the "trapped" Kula plate, which formerly collided with eastern Siberia and the eastern Bering Sea margin during the Mesozic.

Energy resources along the Aleutian Ridge

By M. S. Marlow, D. W. Scholl, A. K. Cooper, and E. C. Buffington

The Aleutian Islands rise above ar arcuate submarine mountain range, the Aleutian Ridge, that separates the north Pacific from tho Bering Sea. Along the crest of this ridge are roughly rectangular shaped basins that are as lerge as 35 by $90 \mathrm{~km}$. The floors of these basins, such as Amukta and Amlia Basins and Pratt Depression, are overlain by about $1,000 \mathrm{~m}$ of water, but they are underlain by as much as $4,000 \mathrm{~m}$ of late Miocene and younger sedimentary beds. Greatly deformed and faulted, these strata are likely prospects for energy resources.

New data on the displacement history of the Lake Clark fault By George Plafker, R. L. Detterman, and Travis Hudson

As part of the Alaska Geologic Earthquake Hazards Project, a reconnaissance investigation was made of the Lake Clark fault (loc. 12) during 1974. 
The prominent topographic trench that marks the fault, for $125 \mathrm{~km}$ from Lake Clark on the southwest to Blockade Glacier on the northeast, appears to be developed along northeast-trending shear zones and foliation in granitic rocks and the Jurassic Talkeetna Formation. This shear zone is at least $20 \mathrm{~m}$ wide and locally may be as much as $275 \mathrm{~m}$ wide where examined near the divide between Blockade Lake and the Tlikakila River valley.

There is no evidence along the fault trace of offset topographic features or glacial deposits suggestive of Quaternary displacement. In the vicinity of Little Lake Clark, offset of the contact between the Talkeetna Formation and an older metamorphic sequence to the southwest and of the contact between a granitic pluton and the enclosing Talkeetna Formation indicate a total dextral displacement of $5 \mathrm{~km} \pm 1 \mathrm{~km}$. The indicated displacement is considerably smaller than the 16 $\mathrm{km}$ that was postulated previously by Ivanhoe (1962). Strike-slip movement of $5 \mathrm{~km}$ occurred on the Lake Clark fault after emplacement of the granitic intrusive, which has yielded a single K/Ar age of 38.6 m.y. (Reed and Lanphere, 1972). The close similarity in lithology and metamorphic grade of rocks on either side of the Lake Clark fault along its entire mapped length suggests that there is no significant vertical component of displacement.

\section{SOUTHERN ALASKA}

West Foreland and Tyonek Formations at Capps Glacier By W. L. Adkison

Exposures of Tertiary rocks on the northwest flank of the Cook Inlet basin near Capps Glacier and along Chuitna River (loc. 14) were measured, described, and sampled in detail for heavy-mineral and palynological studies. The rocks are assigned to the West Foreland and Tyonek Formations. The West Foreland consists of a conglomerate $366 \mathrm{~m}$ thick and lies unconformably on Mesozoic rocks. In the basin to the southeast, the Hemlock Conglomerate overlies the West Foreland and is the most important oil reservoir. At the exposures near Capps Glacier, the Hemlock is missing because of erosion or nondeposition. This conclusion is based on the palynological determinations by $K$. R. Newman (Colorado School of Mines) and on a heavy-minerals study of Kelley (in preparation).
The Tyonek Formation, which unconformably overlies the West Foreland, consists of conglomerates and sandstone in the lower part and sandstone, siltstone, and coal in tre remainder. The total thickness exceeds $671 \mathrm{~m}$, the aggregate thickness of four widely separated measured sections. Stratigraphic relationslips between these sections were only partly determined because of major faulting or the lack of exposures in large areas. This measured section provides valuable surface control for subsurface stratigraphic units that produce oil and gas in the Cook Inlet Tertiary basin.

Bruin Bay fault inactive during the Holocere

By R. L. Detterman, Travis Hudson, and J. M. Hoare

The Bruin Bay fault (loc. 13), one of the many large linear faults in Alaska, extend $₫ 500 \mathrm{~km}$ from Becharof Lake, on the Alaska Peninsula, to near Mt. Susitna, at the head of Cook Inlet. For most of this distance it parallels Cook Inlet and in the Cook Inlet Basin petroleum provirce marks the point between the productive and nonproductive parts of the basin. As part of the Alaska Geologic Earthquake Hazards Project, investigations were carried out in 1974 between Kamishak Bay and Mt. Susitna to determine whether the fault, which is near the population center of Alaska, has been recently active. Stratigraphic displacement of as much as 3,000 had previously been mapped south of Tuxedni Bay (Detterman and Hertsock, 1966). The fault continues north of Tuxedni Bay as a highly sheared and crushed zone $10 \mathrm{C}$ to $300 \mathrm{~m}$ wide in Jurassic intrusive and volcanic rock. Displacement is difficult to determine, but apparently decreases northward as the fault enters Redoubt Bay Flats, and is probably no more than a few hundred metres west of Tyonek where beds of the late Tertiary Kenai Formation $\varepsilon$ re offset. No evidence of displacement could be found in any of the Holocene or Pleistocene surficial deposits that cover many parts of the fault and it is considered to have been inactive since late Tertiary time. The Bruin Bay fault may be a splay of the Castle Mountain fault system, but a positive link with that system cannot be obtained from surface geologic work due to a thick mantle of surficial materials in the probable area of conjunction.

Geohydrology of the Anchorage area, Alasla

By Chester Zenone

Continued urban hydrology studies in the 
Anchorage area (loc. 16) have defined the hydrology of the marshes, swamps, and associated lakes in the western part of the area and outlined the drainage and pollution problems in the Hillside area southeast of Anchorage.

A report on the geology and hydrology of the Eagle River-Chugiak area notes that groundwater supplies adequate for domestic use are of limited extent. The water is of good quality for this purpose.

Ground-water supplies are generally available within 100 feet of the land surface in Glacier Creek valley, Girdwood. Ground- and surface-water quality is acceptable for domestic use, but until a community sewer system is constructed, the potential for pollution of water supplies by septic tank effluent is high. The flood plains of California and Glacier Creeks are flood-prone areas.

A map showing the depth to water in the Anchorage area and an atlas of water-quality data on the Anchorage Borough sanitary landfill have been published.

Water from Ship Creek, diverted at a rate of 4 million gallons a day, was recharged to groundwater aquifers at a test facility located on the Ship Creek alluvial fan. Water levels in the vicinity of the recharge pond have risen as much as 18 feet. Studies related to artificial recharge are continuing.

Turnagain Arm is flood-dominant

By A. T. Ovenshine, Susan Bartsch-Winkler, Neil R. O'Brien, and Daniel E. Lawson

Evidence is accumulating that Turnagain Arm (loc. 15), a 70-km-long estuary near Anchorage, Alaska, is flood-dominant with respect to its long-term sedimentation budget. The principal results leading to this conclusion are:

(1) The sand that fills most of the Arm includes significant quantities of mineral (andalusite, staurolite, garnet, biotite, muscovite, and chlorite) and rock (pumice, coal) fragments that could not have come from the bedrock surrounding Turnagain Arm. These probably were derived from the drainage basin of the Susitna River and have been transported by tidal currents across Knik Arm, upper Cook Inlet, and into Turnagain Arm.

(2) Clast size and imbrication directions of gravel exposed on Girdwood Bar in 1974 indicate predominance of eastward transport, toward the head of the Arm.
(3) A transgressive deposit of intertital sediment has formed at Portage in response to subsidence caused by the Alaskan Earthquake of March 27, 1964. Minerals and rock fragments in the deposit indicate its source was serward in Turnagain Arm and not in the streams that flow from the surrounding mountains into the Portage area.

The flood-dominant character is environmentally significant in wetland management in the upper Cook Inlet area: there seems a high probability that a portion of any solid cr liquid wastes discharged into Cook Inlet near Archorage would be driven by tidal currents into Turnagain Arm.

Geologic discontinuities along two giant linears in southern Alaska

By E. H. Lathram and R. G. H. Raynolds

Major geologic discontinuities occur along the trace of two previously unrecognized giant linears $(>1,000 \mathrm{~km}$ long) identified on the Soil Conservation Services ERTS mosaic. One trends $\varepsilon$ bout N. $85^{\circ} \mathrm{W}$. between latitudes $60^{\circ}$ and $62^{\circ} \mathrm{N}$. from the Alaska-Canada boundary to the delta of the Yukon River. In the Chugach Mounteins the linear is approximately parallel with and just north of the boundary of the area of maximum uplift resulting from the 1964 great Alaska earthquake. In the Cook Inlet area, the linear is the southern margin of an approximately $50 \mathrm{~km}$ zone of linears which coincides with (1) the junction of the Cook Inlet, Susitna and Matanuska lowlands, (2) a deflection in trend of the Border Ranges fault, and (3) a zone of disruption and change in strike in aeromagnetic anomalies. Although the Castle Mountain fault is not offset by the linear, recent movement on the fault is confined to the area north of the linear (R. L. Detterman, oral commun., 1975). In the western Alaska Range, the chain of Holocene volcanoes along the Alaska Peninsula terminates at the linear, as do known Jurassic intrusive bodies. In the lower Kuskokwim and Yukon Rivers area, the linear and the northern margin of the zone coincide with straight courses of the two rivers, and the zone marks the northern extent of a lowland that terminates a northeast trending ridge formed by exposures of the Gemul Group. Other geologic features, including the great faults, are apparently undisturbed by the linear.

The second linear trends northwest from the 


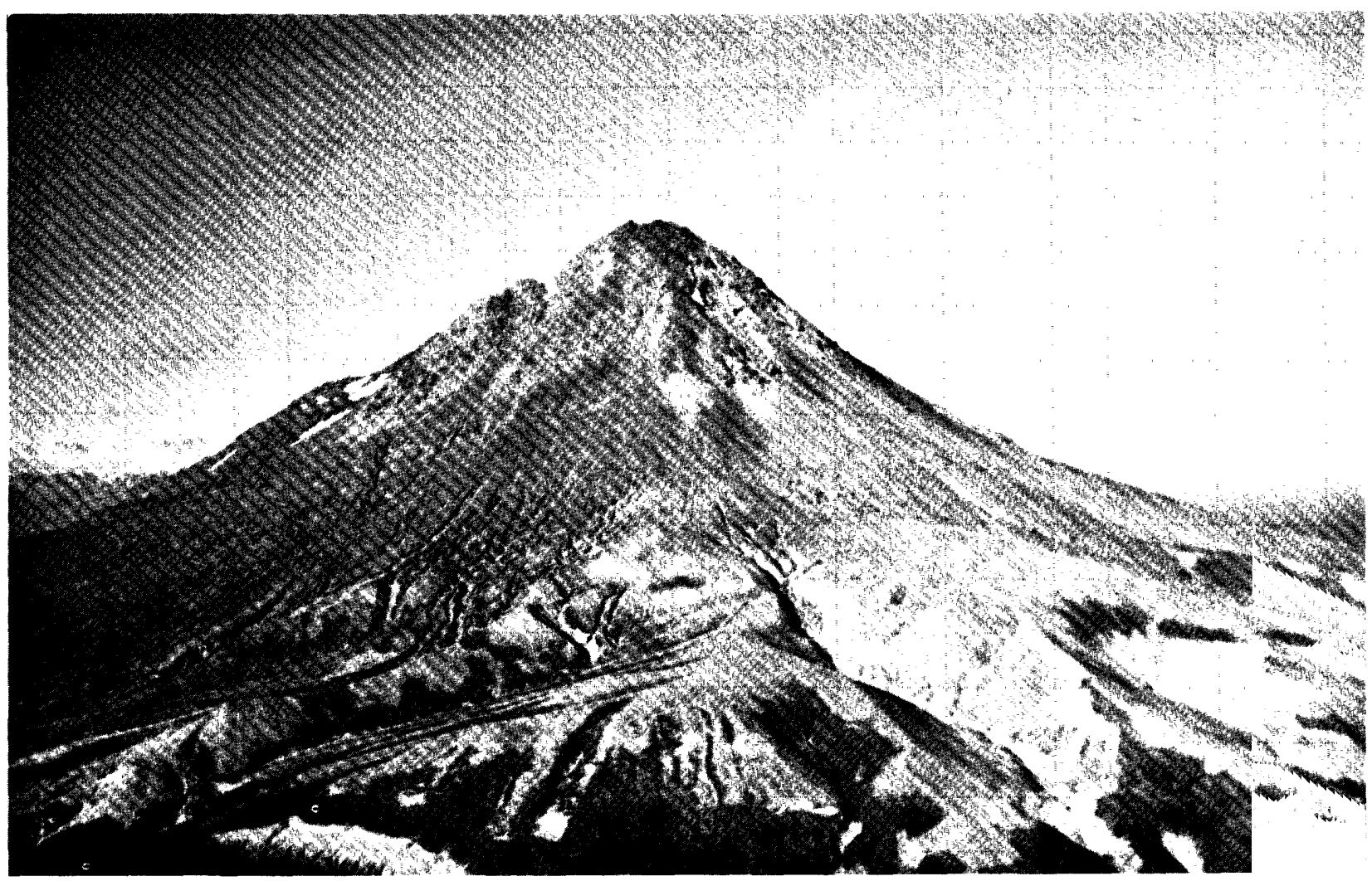

FIGURE 17.-Augustine Island, approximately 185 miles southwest of Anchorage, is closely monitored to warn of impending volcanic activity.

southern terminus of Bering Glacier to near Shaktoolik on Norton Sound. Northwest of the Alaska Range, the position of the linear is ambiguous, and no major geologic discontinuities seem to occur. In the Cook Inlet area, the linear crosses the previously described one, and discontinuities previously described could equally well be ascribed to the second linear. In the area from Anchorage to the edge of the continental shelf, the linear coincides with the boundary between Tertiary and Mesozoic strata in the Prince William Sound region, and with the change in trend of structures on land from northeast to east. On the continental shelf, continuation of the linear coincides with the northeast margin of the "St. Elias transition" of Von Huene and Shor (1969) a zone between the northeast-trending structural regime of the Kodiak-Aleutian area and the east-trending structural regime of the ChugachSt. Elias region, in which both northeast- and east-trending structures occur and are superimposed.
Investigation of earthquakes below the Cook Inlet region of Alaska

By John C. Lahr and Robert A. Page

The southern Alaska seismograph network provides excellent data for resolving the configuration of the Benioff zone in the vicinity of Cook Inlet (Lahr and others, 1974). The apparent thickness of the dipping seismic zone is about 15 $\mathrm{km}$ when projected for $300 \mathrm{~km}$ alons strike. Subdivision of the zone into segments extending $50 \mathrm{~km}$ along strike indicates that, in many areas, earthquakes are concentrated within a zone less than $5 \mathrm{~km}$ thick. Because the locations are based on a flat-layered velocity model, some systematic mislocation is expected due to latera] velocity changes. Thirty-seven events were relocated using a high-velocity dipping plate model, and systematic shifts in epicenters of 0-25 km and in depths of 3-10 km were obtained. The suggested bias in locations, which increases with depth, is tentative because the actual three-dimensional velocity structure is not currently known. Separate focal 
mechanism solutions for about 25 events and composite solutions for more than 100 events reveal that the least compressive stress axis in the intermediate-depth shocks is typically oriented approximately downdip.

Earthquake hazards investigated along Castle Mountain fault in Matanuska Valley

By R. L. Detterman, George Plafker, Travis Hudson, and R. G. Tysdal

Continued investigations by the Alaska Geologic Earthquake Hazards Project in 1974 along the $85 \mathrm{~km}$ Talkeetna segment of the Castle Mountain fault system (loc. 18) indicate a considerable potential for destructive landslides between the Little Susitna River and Caribou Creek. A total of 183 landslides, some of them active, were mapped and about 80 additional areas are considered to be potential slides. They occur in all rock types including surficial materials, but the largest and most abundant are in poorly consolidated Cretaceous and Tertiary sedimentary rock. The size, number, and recency of slides increases greatly east of the Chickaloon River and may correlate with seismic activity within the block between the Castle Mountain and Caribou fault, which is probably the main splay of the Castle Mountain fault system in the eastern Talkeetna Mountains. No conclusive evidence of Holocene offset was found on any of the faults mapped, but many of the landslides are believed to represent Holocene events that could have been initiated by seismic activity on the Castle Mountain system. The westward extension of the Castle Mountain fault system, in the Susitna lowland, is known to have had late Holocene movement (Detterman and others, 1974).

Petrography, tentative age, and correlation of schist, Willow Creek, Talkeetna Mountains, Southern Alaska

By Béla Csejtey, Jr., and James G. Smith

Detailed geologic investigations and K/Ar age determinations on the enigmatic schist at Willow Creek in the Talkeetna Mountains of southern Alaska suggest that the schist underwent a complex and still not fully understood geologic history.

The schist crops out in an approximately $16 \mathrm{~km}$ by $6 \mathrm{~km}$ block in the southwestern Talkeetna Mountains (loc. 17). The block was intruded on the north by Late Cretaceous and early Tertiary plutons and is bounded on the south by the Cenozoic Castle Mountain fault. Rocks lithologi- cally similar to the schist at Willow Creek have not been found in nearby regions.

Lithologically, the schist at Willow Creek is a highly schistose medium-grained ronk with uniform lithology thoughout its exposure area. Its ubiquitous constituents are quartz, muscovite, albite, chlorite, numerous chloritize d crystals of garnet and subordinate biotite, and sparse carbonaceous stringers. Small open fold's and crenulations are common throughout the schist block. The axial planes of these crenulations form an incipient slip cleavage at a large angle to the primary schistosity.

The present mineral assemblage is indicative of the greenschist metamorphic facies (Turner, 1968). However, it is retrograde from higher metamorphism, possibly the amphibolite facies. Evidence is the chloritized garnet and biotite crystals and sparse mineral outlines consisting now of chlorite which are probably pseudomorphs after hornblende. The time relation between this retrograde metamorphism and the incipient slip cleavage is unknown, as is the length of time between these later events and the primary metamorphism.

Potassium-argon age determinations on muscovites from three separate localities yielded early Tertiary ages around $60 \mathrm{~m} . \mathrm{y}$. Although it is not known which metamorphic event or what thermal effect these dates identify, they do not support, in conjunction with regional geologic considerations, the previously assigned Precambrian or early Paleozoic metamorphic age for the s?hist.

The uniform petrography of the sch ist at Willow Creek, the presence of serpentinized ultramafic bodies, and lack of similar rocks in adjacent regions suggest that the schist block is a tectonically emplaced fragment of a larger metamorphic terrane.

Metamorphosed late Paleozoic rocks, similar in lithology and K/Ar ages to rocks of the Willow Creek schist block, occur about $200 \mathrm{~km}$ to the east in the Chugach Mountains, north of the Border Ranges fault (H.C. Berg, oral commun., 1974). These metamorphosed late Paleozoic rocks are interpreted by MacKevett and Plafker (1974) to be part of the upper plate of a late Mesoroic and early Tertiary subduction system.

Ongoing petrologic research an 1 additional $\mathrm{K} / \mathrm{Ar}$ age determinations will hopef ully decipher the complex geologic history of the scl ist at Willow Creek. 
The Landlock fault: part of a major early Tertiary plate boundary in southern Alaska

By Gary R. Winkler and George Plafker

Regional mapping in the Cordova and Bering Glacier $(1: 250,000)$ quadrangles and a detailed reexamination of the "Landlock overthrust fault" of Capps and Johnson (1915) in northeastern Prince William Sound have confirmed the continuity of the Landlock fault as a segment of a major fault system (loc. 21). This system has been traced continuously for $550 \mathrm{~km}$ along the southern margin of the Chugach and Kenai Mountains from the Canada border near Mt. Saint Elias westward to Blying Sound. For most of its length the fault system separates the upper Mesozoic Valdez terrane on the north from the lower Tertiary Orca terrane on the south. The fault system probably extends at least an additional $450 \mathrm{~km}$ southwestward from Blying Sound to Kodiak Island.

The Landlock fault segment of this system extends between the Copper River and Valdez Arm in Prince William Sound. Its trace is mostly sinuous but with short linear sections such as those near Whalen Bay and the head of Port Gravina. Dip of the fault surface is everywhere northward but varies widely from $25^{\circ}$ or less to nearly vertical. Near the head of Simpson Creek, a quartz monzonite pluton approximately $50 \mathrm{~m} . \mathrm{y}$. old is sheared and strongly foliated in a narrow zone adjacent to the major fault trace suggesting some post-early Eocene movement. The irregularity of the Landlock fault trace is most conspicuous and well documented in northeastern Prince William Sound where distinctive basaltic rocks of the Orca Group are transposed relatively beneath slate and sandstone of the Valdez Group. Where topography is steep and the fault surface dips at low angles, as in the area just east of Valdez Arm, flaps of the Valdez Group can be seen to extend as much as $12 \mathrm{~km}$ southwestward over the Orca terrane.

East of the Copper River the Bagley segment of the fault system has a strikingly linear trace along Miles and Bagley Glaciers that is suggestive of a steep to vertical dip. Minor structures indicate predominantly strike-slip movement in this segment, although there is no detectable offset of an early Eocene granodiorite pluton that intrudes the fault zone (Plafker and Lanphere, 1974).

West of Valdez Arm, the Landlock fault and a prominent splay through Jack Bay join, and the trace of the fault system again becomes more regular. The fault system follows a crurvilinear trend around the north and west sides of Prince William Sound to disappear beneath the Gulf of Alaska near Johnstone Bay on the south coast of the Kenai Peninsula. The probable southwestward extension of this system resurfaces on Kodiak Island, where it separates analogous terranes-the upper Mesozoic Kodiak and lower Tertiary Ghost Rocks and Sitkalidak terranes.

The juxtaposition of major geologic terranes across the Landlock fault is equivalent in tectonic style to the older Border Ranges fault system described by MacKevett and Plafker (1.974). The younger system, of which the Landlock fault is a part, is interpreted to be a more southerly plate boundary that developed seaward of tho accreted Valdez terrane during early Tertiary time.

Bering River coal field structure

By R. B. Saunders

Study of the central area of the Bering River Coal Field (loc. 23) has shown that the structure of the area is even more complex than previously believed. The coal-bearing Kushtaka Formation occurs in steeply dipping limbs of axially thrusted chevron folds forming a discordant sexuence of imbrications. Restudy of parts of the Carbon Creek basin previously hidden beneath snow has resulted in drastic reduction of the coal resource estimates for the area. The coal:waste ratio for the Kushtaka Formation is now believed to be 1:40, with an average coal:waste ratio within the so-called coal zones of $1: 20$. Although snectacular coal exposures occur, these are believed to be local thickenings (pods or wedges) incorporated along faults or at the axes of folds. All evidenc $s$ indicates a lack of continuity of these coal beds.

Backsliding(?) along the Ragged Mountain thrust fault By Russell G. Tysdal, Travis Hudson, and George Plafker

The Ragged Mountain fault is a major westward-dipping low-angle thrust fault (loc. 22) separating greenstone and dense sandstone of the early Tertiary Orca Group in the upper plate from siltstone and sandstone of the younger Stillwater and Katalla Formations in the lower plate. Strip mapping along the $30 \mathrm{~km}$ long fault, undertaken as part of the Alaska Geologic Earthquake Hazards Project, reveals surface features suggestive of late Holocene movement on the fault. The surface features include a prominent trench representing the eroded lip of the fault, landslide 
deposits, two ages of talus, and a series of small uphill-facing scarps which cut the older talus at and near the fault trace. The most recent movement is interpreted as westward-directed gravity sliding of the upper plate, possibly initiated by seismic shaking. It is thus opposite in sense to that of the (relative) eastward tectonic thrusting which juxtaposed the Ragged Mountains block over younger sediments sometime during the late Tertiary.

Kennecott-type copper deposits in the Wrangell Mountains By E. M. MacKevett, Jr., and A. K. Armstrong

Detailed stratigraphic and petrographic studies by Armstrong of carbonate rocks that host Kennecott-type copper deposits (loc. 20), augmented by previous geologic studies, indicate that sebkha processes were involved in the ore genesis. The Kennecott deposits are localized in the largely-dolomitic lowermost $100 \mathrm{~m}$ of the Late Triassic Chitistone Limestone. The lowermost $100 \mathrm{~m}$ of the Chitistone formed in cyclic subtidal to supratidal environments and contains abundant stromatolites, mud chips, and pseudomorphs of sulfate-bearing evaporites. This sequence disconformably underlies marine limestone.

The copper in the deposits probably was derived from the Nikolai Greenstone, a thick, widespread succession of subaerial basalts, subjacent to the Chitistone, that has an intrinsically high copper content. A hydrologic regimen during which highly oxygenated water dissolved substantial amounts of copper from the Nikolai and subsequently deposited the copper in the reducing environment of the sebkha is postulated. The deposits' present configurations may reflect some remobilization and displacement during Jurassic or Cenozoic tectonic and plutonic events.

Nabesna quadrangle completed under PAMR AP By H. C. Berg

A major accomplishment by the U.S. Geological Survey during 1974 and 1975 was the preparation and publication of the first interdisciplinary mineral resource assessment of a 1:2,50,000-scale Alaskan quadrangle. The assessment, of the Nabesna quadrangle in south-central Alaska (loc. 28 ), covers an area of $17,600 \mathrm{~km}^{2}\left(6,80 . \mathrm{mi}^{2}\right)$, and is the first to be completed under the PAMRAPAMRAP program (see the writeup under statewide projects of the U.S. Geological Survey). The assessment was carried out by a research team drawn from several branches of the ea rth sciences, and was based on field and laboratory investigations of the geology, geochemistry, geophysics, and satellite imagery. The assessment comprises an interrelated collection of U.S. Geolorical Survey publications: a circular and a folio of maps that includes a modern geologic map, a variety of geochemical and geophysical maps, interpretations of satellite imagery, an analysis of the mineral endowment, and a land status map. The following summary lists the published components and specific topics covered by the Nabesna mineral assessment; the complete references are cited at the end of this section.

Geochemical survey of the Tanacross quadrarole

By Gary C. Curtin, Sherman P. Marsh, Richard B. Tripp, Richard M. O'Leary, Gordon W. Day, and He'en L. Foster

Circular 718 (Richter and others, 1975)

Background information

Miscellaneous Field Studies Maps:

$\begin{aligned} \text { MF-655-A } & \text { (Richter, 1975) } \\ \text { B } & (\text { Marsh, 1975a) } \\ \text { C } & (\text { Marsh, 1975b) } \\ \text { D } & \text { (Marsh, 1975c) } \\ \text { E } & (\text { Marsh, 1975d) } \\ \text { F } & (\text { Marsh, 1975e) } \\ \text { G } & \text { (Marsh, 1975f) } \\ \text { H } & \text { (Griscom, 1975) } \\ \text { I } & \text { (Barnes and Morin, 1975) } \\ \text { J } & \text { (Albert, 1975) Geochemistry: lead } \\ \text { K } & \text { (Richter, Singer, and Cox, 1975) } \\ \text { L } & \text { (U.S. Geological Survey, 1975) }\end{aligned}$




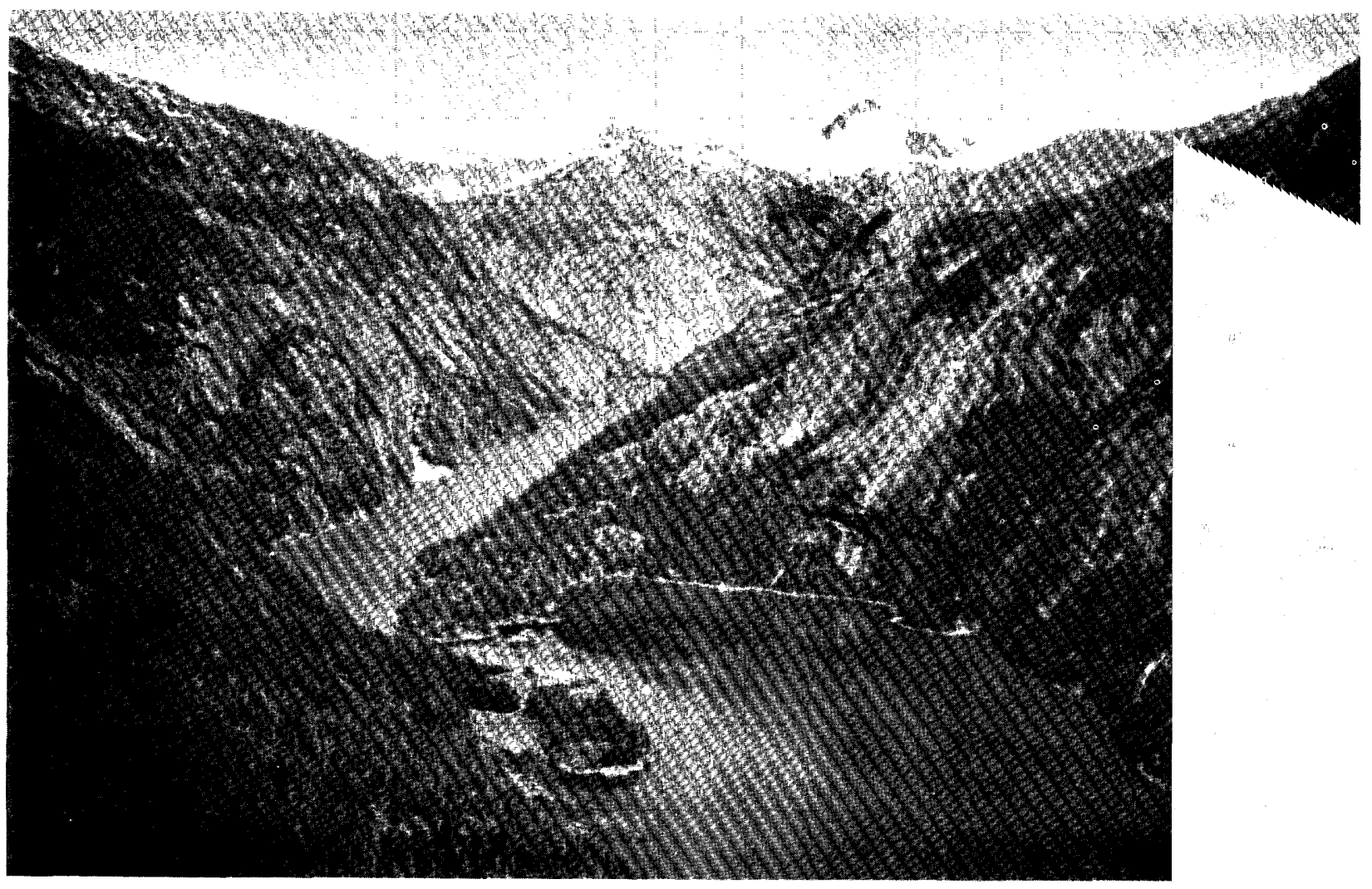

FIgure 18.-The Narrows at the entrance to Fords Terror, Tracy Arm-Fords Terror Wilderness Study area, looking north-northeast.

Preliminary results of a regional geochemical survey during the summer of 1974 in the Tanacross quadrangle (loc. 10), eastern Alaska, have revealed 15 areas where metal values $(\mathrm{Cu}, \mathrm{Pb}, \mathrm{Zn}$, Mo, As) are anomalous. Two of the areas of anomalous metal values outline known porphyry copper deposits and some of the other anomalous areas may reflect similar-though concealedbodies of mineralized rock. The anomalous metal values were detected in the secondary $\mathrm{Fe}$ - and Mn-oxide residue of an oxalic acid extraction of the minus $0.2 \mathrm{~mm}$ (minus $80 \mathrm{mesh}$ ) fraction of stream sediment, and in the ash of both streambank sod beneath the water level and moss growing in the streams.

The results also suggest that these three stream sampling media show promise as useful geochemical sampling tools in the subarctic permafrost terrane of the Yukon-Tanana upland. The oxalic acid extraction of the stream sediment takes up both secondary $\mathrm{Fe}$ - and Mn-oxides and those elements scavenged from solution by the oxides (Alminas and Mosier, oral commun., 1975).
Likewise, the moss (Whitehead and Brooks, 1969) and the decaying organic matter in the streambank sod (Brundin and Nairis, 1972) act as scavengers of elements in solution in the streams. The element content of these media, therefore, reflects the abundance of elements which are subject to solution and dispersion within the drainage system. Our studies indirate that the element content of these media better reflects the distribution and abundance of elements which are being leached and dispersed from mineralized zones than does the element content in clastic materials that constitute the bulk of the minus 0.2 $\mathrm{mm}$ fraction of stream sediment. Further, comparative studies were made between the minus 0.2 $\mathrm{mm}$ fraction of the stream sedinent and the secondary oxide residue of the oxalic acid extraction of the stream sediment. These studies showed that element values in the secondary oxide residue were relatively high and the rangos in element values among samples were greater than were those in the minus $0.2 \mathrm{~mm}$ fraction of the stream sediments. These results substantiate the findings 


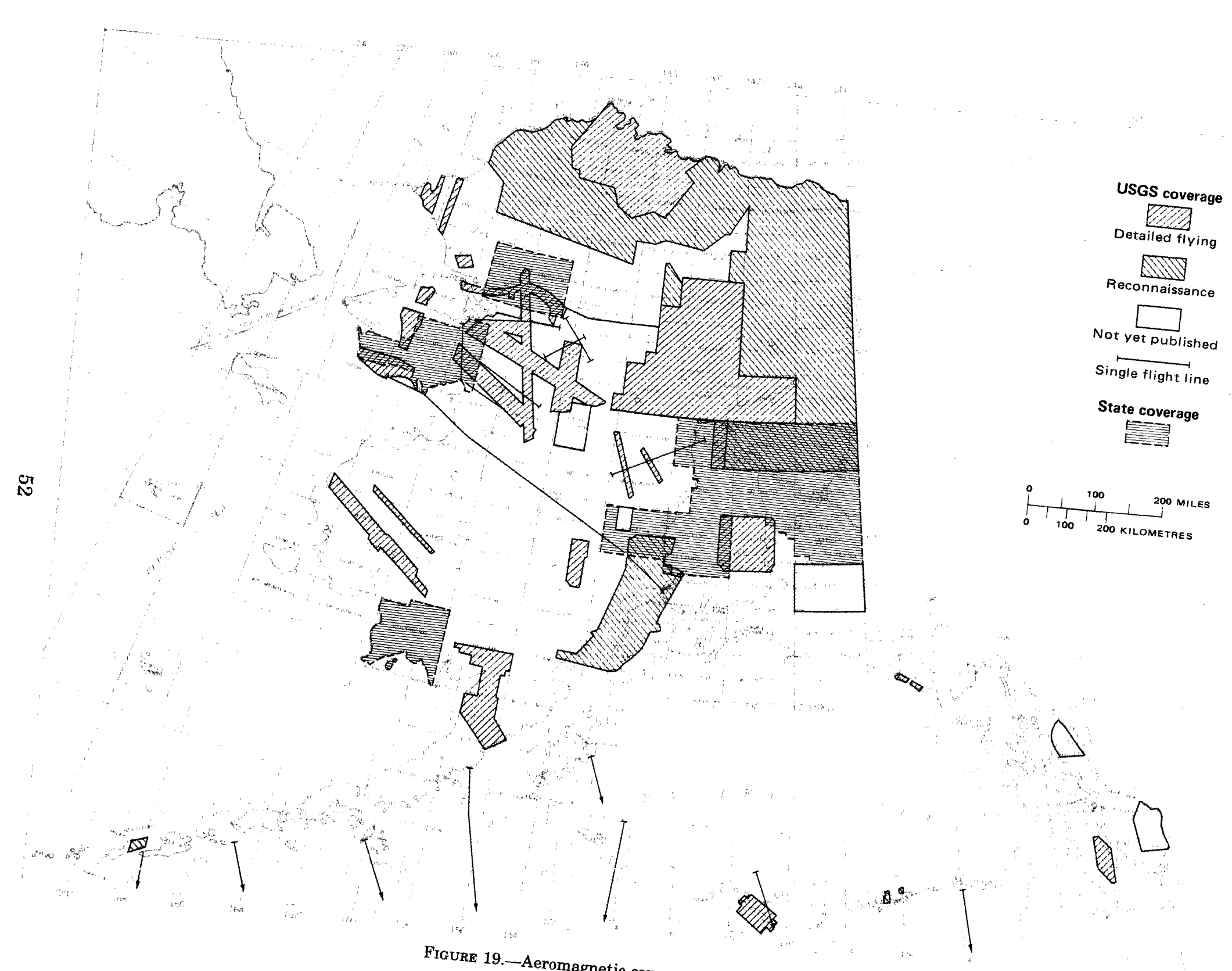

FIGURE 19.-Aeromagnetic coverage for the State of Alaska. 
of Alminas and Mosier (oral commun., 1975) which show that very weak anomalies in materials such as stream sediments can be greatly enhanced by leaching the stream sediment material with oxalic acid and analyzing the secondary $\mathrm{Fe}$ - and $\mathrm{Mn}$ oxide residue of the leachate.

\section{SOUTHEASTERN ALASKA}

Coast Range transect in Tracy Arm-Fords Terror Wilderness Study Area contains seven major belts of rock

By David A. Brew, Arthur B. Ford, Donald Grybeck, and Constance J. Nutt

A series of seven more or less continuous but irregular belts are included in the Tracy ArmFords Terror Wilderness Study Area between the tidewater of Stephens Passage and the International Boundary at the crest of the Coast Range (loc. 26). The southwestern three of the southeasttrending series consist of low-grade metamorphosed detrital clastic and volcanic rocks of probable late Paleozoic or early Mesozoic age, cut by complicated granite, diorite, and hornblendite intrusions with locally extensive contact metamorphic effects. The middle belt of the series consists of higher grade metamorphic rocks that define the southwestern edge of the Coast Range batholithic complex. The original ages of the rocks in this belt are uncertain, but are probably also late Paleozoic or early Mesozoic. The northeastern three belts of the series consist of a remarkably long foliated quartz diorite sill of inferred late Mesozoic age; a broad terrane of gneiss, schist, and marble of uncertain original age; and, along the International Boundary, a discontinuous belt of granite and granodiorite bodies of inferred mid-Tertiary age.

Tertiary granitic rocks dominate Coast Range batholithic complex in northern southeastern Alaska

By David A. Brew, Arthur B. Ford, Donald Grybeck, and Constance J. Nutt

New studies along the International Boundary in the Tracy Arm-Fords Terror Wilderness Study Area, continuing studies in the Juneau Icefield area, and available reconnaissance information on intervening and adjacent areas indicate that granodiorite and quartz monzonite of established or inferred mid-Tertiary age probably underlie most of the Coast Range batholithic complex between the Stikine River and the Skagway area (loc. 25). Several separate bodies are represented, the largest of which appears to be the 50 m.y. old "Turner Lake" body of the Juneau Icefield area. In general, the bodies intrude granitic gneisses to the southwest, but locally they extend across the granitic gneiss belt almost to the schist belt that forms the southwest boundary of the Coast Range batholithic complex. To the northeast, the bodies intrude thermally metamorphosed rocks that are largely of Mesozoic age. At a very few places the Tertiary granitic bodies are associated with volcanic rocks that may be comagmatic.

Municipal water-supply investigations

By G. S. Anderson

Work accomplished on the continuing cooperative program with the State of Alaska, Department of Natural Resources includes administrative reports on Pelican and Skagray (loc. 24). Pelican presently has enough water for its needs. Additional needs can be met by improving the current water distribution system, obtaining water from a lake, or by developing a groundwater source.

\section{REFERENCES CITED IN SUMMARY OF IMPORTANT RESULTS, 1974}

Alaska Division of Geological and Geophysical Surveys, 1973, Annual report 1972: Anchorage, Alaska, p. 34-36.

Albert, N. R. D., 1975, Interpretation of Farth Resources Technology Satellite imagery of the Nabesna quadrangle, Alaska: U.S. Geol. Survey Misc. Field S rdies Map MF655-J, 2 sheets, scale 1:250,000.

Barnes, D. F., and Morin, R. L., 1975, Gravity map of the Nabesna quadrangle, Alaska: U.S. Geol. Survey Misc. Field Studies Map MF-655-I, 1 sheet, scale 1:250,000.

Beikman, H. M., 1974, Preliminary geoloric map of the southwest quadrant of Alaska: U.S. Gesl. Survey Misc. Field Studies Map MF-611, 2 sheets, scrle 1:1,000,000.

-1974, Preliminary geologic map of the southeast quadrant of Alaska: U.S. Geol. Survey Misc. Field Studies Map MF-612, 2 sheets, scale 1:1,000,00C

Brosgé, W. P., and Dutro, J. T., Jr., 1973, Paleozoic rocks of northern and central Alaska, in Pitcher, M., (ed.), Arctic geology: Am. Assot. Petroleum Geologists Mem. 19, p. 361-375.

Brundin, N. H., and Nairis, B., 1972, Alternative sample types in regional geochemical prospecting: Jour. Geochem. Explor., v. 1, no. 1, p. 7-46.

Capps, S. R., and Johnson, B. L., 1915, The Ellamar district, Alaska: U.S. Geol. Survey Bull. 605, 125 p.

Churkin, Michael, Jr., 1973, Paleozoic and Precambrian rocks of Alaska and their role in the structurel evolution: U.S. Geol. Survey Prof. Paper 740, 64 p.

Cobb, E. H., 1974a, Synopsis of the mineral resources and geology of Alaska: U.S. Geol. Survey Bull. 1307, 53 p. 
1974b, Geological Survey open-file reports on Alaska indexed by quadrangle: U.S. Geol. Survey open-file report 74-7, $116 \mathrm{p}$.

-1974c, Selected U.S. Bureau of Mines reports on Alaska indexed by quadrangle: U.S. Geol. Survey open-file report 74-52, $40 \mathrm{p}$.

-1974d, Geological Survey maps (other than topographic maps) of Alaska indexed by quadrangle: U.S. Geol. Survey open-file report $74-84,38$ p.

-1974e, Reports of the Alaska Division of Geological and Geophysical Surveys and predecessor agencies, 19131973 , indexed by quadrangle: U.S. Geol. Survey open-file report 74-209, $112 \mathrm{p}$.

1974f, Geological Survey published reports on Alaska, 1960-1973, indexed by quadrangle: U.S. Geol. Survey open-file report $74-210,163 \mathrm{p}$.

$-1974 \mathrm{~g}$, Geological Survey published reports on Alaska, 1940-1959, indexed by quadrangle: U.S. Geol. Survey open-file report $74-261,71 \mathrm{p}$.

_ $1974 \mathrm{~h}$, Geological Survey published reports on Alaska, 1915-1939, indexed by quadrangle: U.S. Geol. Survey open-file report $74-335,159 \mathrm{p}$.

1974i, Geological Survey published reports on Alaska, 1884-1914, indexed by quadrangle: U.S. Geol. Survey open-file report $74-345,126 \mathrm{p}$.

$-1974 \mathrm{j}$, Index of metallic mineral deposits of Alaska compiled from published reports of Federal and State agencies through 1972: Natl. Tech. Inf. Service PB-233 217/AS, $590 \mathrm{p}$.

Detterman, R. L., and Hartsock, J. K., 1966, Geology of the Iniskin-Tuxedni region, Alaska: U.S. Geol. Survey Prof. Paper 512, $78 \mathrm{p}$.

Detterman, R. L., Plafker, George, Hudson, Travis, Tysdal, R. G., and Pavoni, Nazario, 1974, Surface geology and Holocene breaks along the Susitna segment of the Castle Mountain fault, Alaska: U.S. Geol. Survey Misc. Field Studies Map MF-618, 1 sheet, scale 1:24,000.

Eakin, H. M., 1918, The Cosna-Nowitna region, Alaska: U.S. Geol. Survey Bull. 667, 54 p.

Forbes, R. B., Hamilton, Thomas, Tailleur, I. L., Miller, T. P., and Patton. W. W., Jr., 1971, Tectonic implications of blueschist facies metamorphic terranes in Alaska: Nature, Phys. Sci., v. 234, p. 106-108.

Gonzales, D. D., Wolletz, L. E., and Brethauer, G. E., 1974, Bathymetry of Cannikin Lake, Amchitka Island, Alaska, with an evaluation of computer mapping techniques: U.S. Geol. Survey rept. USGS-474-203, 24 p.; available from U.S. Dept. Commerce, Natl. Tech. Inf. Service, Springfield, Va. 22151.

Grantz, Arthur, 1966, Strike-slip faults in Alaska: U.S. Geol. Survey open-file report, $82 \mathrm{p}$.

Griscom, Andrew, 1975, Aeromagnetic map and interpretation of the Nabesna quadrangle, Alaska: U.S. Geol. Survey Misc. Field Studies Map MF-655-H, 2 sheets, scale $1: 250,000$.

Haites, T. B., 1960, Transcurrent faults in western Canada: Alberta Soc. Petroleum Geologists Jour., v. 8, p. 33-79.

Hoare, J. M., and Coonrad, W. L., 1961, Geologic map of the Goodnews quadrangle: U.S. Geol. Survey Misc. Geologic Inv. Map I-339, 1 sheet, scale 1:250,000.

Ivanhoe, L. F., 1962, Right-lateral strike-slip movement along the Lake Clark fault, Alaska: Geol. Soc. America Bull., v. 73, p. 911-912.
Keith, T. E. C., and Foster, H. L., 1973, Basic data on the ultramafic rocks of the Eagle quadrangle, east-central Alaska: U.S. Geol. Survey open-file report, 4 sheets.

Lahr, J. C., Engdahl, E. R., and Page, R. A., 1974, Locations and focal mechanisms of intermediate depth earthquakes below Cook Inlet, Alaska: EOS, Am. Geophys. Union Trans., v. 55, no. 4, p. 349.

Lathram, E. H., 1973, Tectonic framework of northern and central Alaska, in Pitcher, M., (ed.), Arctic geology: Am. Assoc. Petroleum Geologists Mem. 19, p. 351-360.

Lathram, E. H., and Albert, N. R. D., 1975, Signific ance of space image linears in Alaska, in 1st International conference on the new basement tectonics, June 3-5, 1974, Proc.: Utah Geological Association, Salt Lake City, Utar (in press).

MacKevett, E. M., Jr., and Plafker, George, 1974, The Border Ranges fault in south-central Alaska: U.S. Geol. Survey, Jour. Research, v. 2, no. 2, p. 323-329.

Marsh, S. P., 1975a, Geochemical and generalized geologic map showing distribution and abundance of copper in the Nabesna quadrangle, Alaska: U.S. Geol. Survey Misc. Field Studies Map MF-655-B, 1 sheet, scale 1:250,000.

-1975b, Geochemical and generalized geologic map showing distribution and abundance of lead in the Nabesna quadrangle, Alaska: U.S. Geol. Survey Misc. Field Studies Map MF-655-C, 1 sheet, scale 1:250,000. 1975c, Geochemical and generalized giologic map showing distribution and abundance of gold in the Nabesna quadrangle, Alaska: U.S. Geol. Survey Misc. Field Studies Map MF-655-D, 1 sheet, scale 1:250,000. -1975d, Geochemical and generalized giologic map showing distribution and abundance of chromium in the Nabesna quadrangle, Alaska: U.S. Geol. S'urvey Misc. Field Studies Map MF-655-E, 1 sheet, scale 1:250,000. 1975e, Geochemical and generalized geologic map showing distribution and abundance of cobalt in the Nabesna quadrangle, Alaska: U.S. Geol. Sirrvey Misc. Field Studies Map MF-655-F, 1 sheet, scale 1:250,000.

-1975f, Perspective diagrams showing geochemical abundance of silver, lanthanum, molybdenum, nickel, vanadium, yttrium, and zinc in the Nabesna quadrangle, Alaska: U.S. Geol. Survey Misc. Field S'udies Map MF-655-G, 1 sheet, scale 1:250,000.

Patton, W. W., Jr., and Hoare, J. M., 1968, The Kaltag fault, west-central Alaska: U.S. Geol. Survey Prof. Paper 600-D, p. D147-D153.

Pessel, G. H., Garland, R. E., Tailleur, I. L., and Eakins, G. R., 1973, Preliminary geologic map of southeastern Ambler River and part of Survey Pass quadrangles, Alaska: Alaska Div. Geol. and Geophys. Surveys open-file report 28, 2 sheets, scale 1:63,360.

Péwé, T. L., and Bell, J. W., Map showing distribution of permafrost in the Fairbanks D-2 SW quadrangle, Alaska: U.S. Geol. Survey Misc. Geologic Inv. Map I-829-B, 7 p., 1 sheet, scale 1:24,000 (in press).

-Map showing ground water conditions in $t \mathrm{~s}$ Fairbanks D-2 SW quadrangle, Alaska: U.S. Geol. S'rvey Misc. Geologic Inv. Map I-829-C, 7 p., 1 sheet, scale 1:24,000 (in press).

Map showing construction materials in the Fairbanks D-2 SW quadrangle, Alaska: U.S. Geol. S urvey Misc. Geologic Inv. Map I-829-D, 7 p., 1 sheet, scale 1:24,000 (in press).

Map showing foundation conditions in the Fairbanks 
D-2 SW quadrangle, Alaska: U.S. Geol. Survey Misc. Geologic Inv. Map I-829-E, 19 p., 2 sheets, scale 1:24,000 (in press).

Map showing the distribution of permafrost in the Fairbanks D-2 NW quadrangle, Alaska: U.S. Geol. Survey Misc. Field Studies Map (in press).

-Map showing ground water conditions in the Fairbanks D-2 NW quadrangle, Alaska: U.S. Geol. Survey Misc. Field Studies Map (in press).

-Map showing construction materials in the Fairbanks D-2 NW quadrangle, Alaska: U.S. Geol. Survey Misc. Field Studies Map (in press).

Map showing foundation conditions in the Fairbanks D-2 NW quadrangle, Alaska: U.S. Geol. Survey Misc. Field Studies Map (in press).

-Map showing the distribution of permafrost in the Fairbanks D-2 NE quadrangle, Alaska: U.S. Geol. Survey Misc. Field Studies Map (in press).

-Map showing ground water conditions in the Fairbanks D-2 NE quadrangle, Alaska: U.S. Geol. Survey Misc. Field Studies Map (in press).

Map showing construction materials in the Fairbanks D-2 NE quadrangle, Alaska: U.S. Geol. Survey Misc. Field Studies Map (in press).

Map showing foundation conditions in the Fairbanks D-2 NE quadrangle, Alaska: U.S. Geol. Survey Misc. Field Studies Map (in press).

Péwé, T. L., Bell, J. W., Forbes, R. B., and Weber, F. R., 1975, Geologic map of the Fairbanks D-2 SW quadrangle, Alaska: U.S. Geol. Survey Misc. Geologic Inv. Map I-829-A, 11 p., 1 sheet, scale 1:24,000 (in press).

-Geologic map of the Fairbanks D-2 NW quadrangle, Alaska: U.S. Geol. Survey Misc. Geologic Inv. Map I-907, 1 sheet, scale 1:24,000 (in press).

Geologic map of the Fairbanks D-2 NE quadrangle, Alaska: U.S. Geol. Survey Misc. Geologic Inv. Map, 30 p., 1 sheet, scale 1:24,000 (in press).

-Geologic map of the Fairbanks D-2 SE quadrangle, Alaska: U.S. Geol. Survey Misc. Geologic Inv. Map, 1 sheet, scale 1:24,000 (in press).

Péwé, T. L., Bell, J. W., Williams, J. R., and Paige, R. A., Geologic map of the Fairbanks D-1 SW quadrangle, Alaska: U.S. Geol. Survey Misc. Geologic Inv. Map, 17 p., 1 sheet, scale 1:24,000 (in press).

Plafker, George, and Lanphere, M. A., 1974, Age of the Bagley fault, in Carter, Claire, (ed.), U.S. Geological Survey Alaska Program, 1974: U.S. Geol. Survey Circ. 700, p. 52.

Reed, B. L., and Lanphere, M. A., 1972, Generalized geologic map of the Alaska-Aleutian Range batholith showing potassium-argon ages of the plutonic rocks: U.S. Geol. Survey Misc. Field Studies Map MF-372, 2 sheets, scale $1: 1,000,000$.

Richter, D. H., 1975, Geologic map of the Nabesna quadrangle, Alaska: U.S. Geol. Survey Misc. Field Studies Map MF655-A, 1 sheet, scale 1:250,000.

Richter, D. H., Albert, N. R. D., Barnes, D. F., Griscom, Andrew, Marsh, S. P., and Singer, D. A., 1975, The Alaskan mineral resource assessment program: Background information to accompany folio of geologic and mineral resource maps of the Nabesna quadrangle, Alaska: U.S. Geol. Survey Circ. 718, 11 p.

Richter, D. H., Singer, D. A., and Cox, D. P., 1975, Mineral resources map of the Nabesna quadrangle, Alaska: U.S.
Geol. Survey Misc. Field Studies Map MF-655-K, 1 sheet, scale 1:250,000.

Sikabonyi, L. A., and Rodgers, W. J., 1959, Pal€ozoic tectonics and sedimentation in the northern half of the West Canadian Basin: Jour. Alberta Soc. Petrole גm Geologists, v. 7, p. 193-216.

Thomas, G. E. 1974, Lineament-block tectonics: WillistonBlood Creek Basin: Am. Assoc. Petroleum Geologists Bull., v. 58 , p. $1305-1322$.

Turner, F. J., 1968, Metamorphic petrology: New York, McGraw-Hill, 403 p.

U.S. Geological Survey, 1975, Status of land in the Nabesna quadrangle, Alaska: U.S. Geol. Survey Misc. Field Studies Map MF-655-L, 1 sheet, scale 1:250,000.

Von Huene, Roland, and Shor, G. G., Jr., 1969, The structure and tectonic history of the eastern Aleutiar. Trench: Geol. Soc. America Bull., v. 80, p. 1889-1902.

Whitehead, N. E., and Brooks, R. R., 1969, Aquatic bryophytes as indicators of uranium mineralization: The Bryologist, v. 72 , no. 4 , p. $501-507$.

Zwart, H. J., Corvalan, J., James, H. L., Miyashiro, A., Saggerson, E. P., Sobolev, V. S., Subramaniam, A. P., and Vallance, T. G., 1967, A scheme of metamomphic facies for the cartographic representation of regional metamorphic belts: International Union of Geological Scionces, Geological Newsletter, v. 1967, no. 2, p. 57-72.

\section{REPORTS ON ALASKA PUBLISHED BY U.S. GEOLOGICAL SURVEY I ' 1974}

The basic task of the U.S. Geological Survey is to obtain, analyze, and interpret data on the land and water of the United States. The primary products of the Geological Survey are published maps and reports.

The publications of the Geological Survey in 1974 that concern Alaska are listed in this section. Survey authors are also frequent contributors to the journals of scholarly or technical societies and references to these reports are listed in standard bibliographies. Information on the availability of U.S. Geological Survey publications relating to Alaska may be obtained from the Public Inquiries Office, U.S. Geological Survey, 218 E Street, Anchorage, Alaska 99501. Reports Fublished in scholarly or technical journals may be consulted in many college, industrial, and public libraries; sometimes single copies may be obtained by writing to the senior author.

Barnes, Peter, Leong, Kam, and Gustafson, Charles, 1974, Map showing distribution of copper, lead, zinc, mercury, and arsenic in the sediments off the coast of northern Alaska: U.S. Geol. Survey Misc. Field Studies Map MF-614, 1 sheet, scale 1:1,375,000.

Beikman, H. M., 1974, Preliminary geologic map of the southwest quadrant of Alaska: U.S. Geol. Survey Misc. Field Studies Map MF-611, 2 sheets, scale 1:1,000,000. 
1974, Preliminary geologic map of the southeast quadrant of Alaska: U.S. Geol. Survey Misc. Field Studies Map MF-612, 2 sheets, scale 1:1,000,000.

Berg, H. C., 1974, Geology of Gravina Island, Alaska: U.S. Geol. Survey Bull. 1373, 41 p.

Berg, H. C., Elliot, R. L., Smith, J. G., Pittman, T. L., and Kimball, A. L., 1974, Magnetic tape containing spectrographic and chemical analyses of rock and stream-sediment samples from the Granite Fiords Wilderness study area, Alaska: U.S. Dept. of Commerce, Natl. Tech. Inf. Service, PB-232 049.

Berryhill, H. L., Jr., 1974, The worldwide search for petroleum offshore-A status report for the quarter century, 1947-72: U.S. Geol. Survey Circ. 694, 27 p.

Boerngen, J. G., Hamilton, J. C., Marsh, W. R., and Rosenblum, Sam, 1974, Description of magnetic tape containing results of semiquantitative spectrographic analyses of the nonmagnetic fractions of 1,069 Alaskan alluvial concentrates: U.S. Dept. of Commerce, Natl. Tech. Inf. Service, PB-231 511/AS, $24 \mathrm{p}$.

Brew, D. A., 1974, Environmental impact analysis: The example of the proposed trans-Alaska pipeline: U.S. Geol. Survey Circ. 695, $16 \mathrm{p}$.

Carter, Clair, (ed.), 1974, United States Geological Survey Alaska program, 1975: U.S. Geol. Survey Circ. 700, 63 p.

Childers, J. M., 1974, Flood surveys along TAPS route, Alaska: U.S. Geol. Survey Basic-Data report, 16 p.

Christian, R., Eberlein, G. D., and Konert, J., 1974, Optical and $\mathrm{X}$-ray crystallographic investigations of strontioginorites: U.S. Geol. Survey Jour. Research, v. 2, no. 6, p. 699-700.

Cobb, E. H., 1974, Geological Survey open-file reports of Alaska indexed by quadrangle: U.S. Geol. Survey open-file report 74-7, $116 \mathrm{p}$.

1974, Geological Survey published maps (other than topographic maps) of Alaska indexed by quadrangle: U.S. Geol. Survey open-file report 74-84, 41 p.

1974, Geological Survey published reports on Alaska, 1884-1914, indexed by quadrangle: U.S. Geol. Survey open-file report $74-345,130 \mathrm{p}$.

1974, Geological Survey published reports on Alaska, 1915-1939, indexed by quadrangle: U.S. Geol. Survey open-file report $74-335,162 \mathrm{p}$.

1974, Geological Survey published reports on Alaska, 1940-1959, indexed by quadrangle: U.S. Geol. Survey open-file report $74-261,71 \mathrm{p}$.

1974, Geological Survey published reports on Alaska, 1960-1973, indexed by quadrangle: U.S. Geol. Survey open-file report $74-210,166$ p.

1974, Index of metallic mineral deposits of Alaska compiled from published reports of Federal and State agencies through 1972: U.S. Dept. Commerce, Natl. Tech. Inf. Service PB-233 217/AS, 590 p.

1974, Reports of the Alaska Division of Geological and Geophysical Surveys and predecessor agencies, 19131973 , indexed by quadrangle: U.S. Geol. Survey open-file report $74-209,115 \mathrm{p}$.

-1974, Selected U.S. Bureau of Mines reports on Alaska indexed by quadrangle: U.S. Geol. Survey open-file report 74-52, 40 p.

1974, Synopsis of the mineral resources and geology of Alaska: U.S. Geol. Survey Bull. 1307, 53 p.

Csejtey, Béla, Jr., 1974, Reconnaissance geologic investiga- tions in the Talkeetna Mountains, Alaska: U.S. Geol. Survey open-file report $74-147,53$ p.; 1 sheet, scale $1: 63,360$.

Csejtey, Béla, Jr., and Patton, W. W., Jr., 1974, Petrology of the nepheline syenite of St. Lawrence Island, Alaska: U.S. Geol. Survey Jour. Research, v. 2, no. 1, p. 41-47.

Davis, G. H., and Wood, L. A., 1974, Water demands for expanding energy development: U.S. Geol. Survey Circ. $703,14 \mathrm{p}$.

Day, G. W., Crim, W. D., Rosenblum, Sam, Overstreet, W. C., and Larson, A. L., 1974, Magnetic tape containing results of semiquantitative spectrographic analyses of the magnetic fractions of 680 Alaskan alluvial concentrates: U.S. Dept. Commerce, Natl. Tech. Inf. Service PB-229 947/AS.

Dearborn, L. L., and Freethey, G. W., 1974, Water-table contour map, Anchorage area, Alaska: U.S. Geol. Survey open-file report, 1 sheet, scale 1:24,000.

Detterman, R. L., 1974, Fence diagram showing lithologic facies of the Sadlerochit formation (Permian and lower Triassic), northeastern Alaska: U.S. Geol. Survey Misc. Field Studies Map MF-584, 1 sheet, scale 1:500,000.

Detterman, R. L., Plafker, George, Hudson, Travis, Tysdal, R. G., and Pavoni, Nazario, 1974, Surface geology and Holocene breaks along the Susitna segment of the Castle Mountain fault, Alaska: U.S. Geol. Survey Misc. Field Studies Map MF-618, 1 sheet, scale 1:24,000.

Detterman, R. L., and Reed, B. L., 1974, Surficial deposits of the Iliamna quadrangle, Alaska: U.S. Geol. Survey Bull. 1368-A, p. A1-A64.

Foster, H. L., and Keith, T. E. C., 1974, Ultramafis rocks of the Eagle quadrangle, east-central Alaska: U.S. Geol. Survey Jour. Research, v. 2, no. 6, p. 657-669.

Freethey, G. W., Reeder, J. W., and Barnwell, W. W., 1974, Map showing depth to water Anchorage area, Alaska: U.S. Geol. Survey open-file report, 1 sheet, scale 1:24,000.

Frezon, S. E., 1974, Summary of 1972 oil and gas statistics for onshore and offshore areas of 151 countries: U.S. Geol. Survey Prof. Paper 885, 163 p.

Grantz, Arthur, McHendrie, A. G., Nilsen, T. H., and Yorath, C. J., 1974, Seismic reflection profiles on the continental shelf and slope between Bering Strait and Barrow, Alaska, and Mackenzie Bay, Canada: U.S. Geol. Survey open-file report, 49 sheets.

Grantz, Arthur, McHendrie, A. G., Nilsen, T. H., Yorath, C. J., and Phillips, J. D., 1974, Digital magnetic trnes of single channel seismic reflection profiles on the continental shelf and slope between Bering Strait and Barrow, Alaska, and Mackenzie Bay, Canada: U.S. Dept. Commerce, Natl. Tech. Inf. Service PB-232, 344, $12 \mathrm{p}$.

Hamilton, J. C., Boerngen, J. G., Marsh, W. R., and Rosenblum, Sam, 1974, Magnetic tape containing results of semiquantitative spectrographic analyses of 1,069 Alaskan alluvial concentrates: U.S. Dept. Commerce, Natl. Tech. Inf. Service, PB-231 246.

Hanna, W. F., Ruppel, B. D., McHendrie, A. G.. and Sikora, R.F., 1974, Residual magnetic anomaly and free-air gravity anomaly profiles, 1973, on continental shelf and slope between Bering Strait and Barrow, Alaska, and MacKenzie Bay, Canada: U.S. Geol. Sur'ey open-file report 74-6, 6 p.

Hawley, C. C., and Clark, A. L., 1974, Geology and mineral deposits of the Upper Chulitna district, Alaska: U.S. Geol. Survey Prof. Paper 758-B, p. B1-B47. 
Johnson, G. R., and Sainsbury, C. L., 1974, Aeromagnetic and generalized geologic map of the west-central part of the Seward Peninsula, Alaska: U.S. Geol. Survey Geophys. Inv. Map GP-881, 1 sheet, scale 1:250,000.

Kachadoorian, Reuben, 1974, Geology of the Devil Canyon dam site, Alaska: U.S. Geol. Survey open-file report 74-40, 24 p.

Lahr, J. C., Page, R. A., and Thomas, J. A., 1974, Catalog of earthquakes in south-central Alaska, April-June 1974: U.S. Geol. Survey open-file report, 35 p.

Lemke, R. W., 1974, Reconnaissance engineering geology of the Wrangell area, Alaska, with emphasis on evaluation of earthquake and other geologic hazards: U.S. Geol. Survey open-file report, $103 \mathrm{p}$.

McCoy, G. A., 1974, Preconstruction assessment of biological quality of the Chena and Little Chena Rivers in the vicinity of the Chena Lakes flood control project near Fairbanks, Alaska: U.S. Geol. Survey Water-Resources Inv. WRI 29- 74, 84 p.

MacKevett, E. M., Jr., and Plafker, George, 1974, The Border Ranges fault in south-central Alaska: U.S. Geol. Survey Jour. Research, v. 2, no. 3, p. 323-329.

MacKevett, E. M., Jr., Robertson, E. C., and Winkler, G. R., 1974, Geology of the Skagway B-3 and B-4 quadrangles, southeastern Alaska: U.S. Geol. Survey Prof. Paper 832, $33 \mathrm{p}$.

MacKevett, E. M., Jr., and Smith, J. G., 1972, Geologic map of the McCarthy B-6 quadrangle, Alaska: U.S. Geol. Survey Geol. Quad. Map GQ-1035, 1 sheet, scale 1:63,360.

Marvin, R. F., 1974, A tabulation of K-Ar, Rb-Sr, and $\mathrm{Pb}-\alpha$ ages obtained for materials within the United States (including Alaska and Hawaii) during the years 1956 through 1964: U.S. Geol. Survey open-file report, $174 \mathrm{p}$.

1974, A tabulation of $\mathrm{K}-\mathrm{Ar}, \mathrm{Rb}-\mathrm{Sr}$, and $\mathrm{Pb}-\alpha$ ages obtained for materials within the United States (including Alaska and Hawaii) during the years 1965 through 1968: U.S. Geol. Survey open-file report, 245 p.

1974, A tabulation of K-Ar, Rb-Sr, and $\mathrm{Pb}-\alpha$ ages obtained for materials within the United States (including Alaska and Hawaii) during the years 1969 through 1971: U.S. Geol. Survey open-file report, 193 p.

Moore, J. C., 1974, Geologic and structural map of part of the outer Shumagin Islands, southwestern Alaska: U.S. Geol. Survey Misc. Inv. Map I-815, 1 sheet, scale 1:63,360.

-1974 , Geologic and structural map of the Sanak Islands, southwestern Alaska: U.S. Geol. Survey Misc. Geol. Inv. Map I-817, 1 sheet, scale 1:63,360.

Nauman, J. W., and Kernodle, D. R., 1974, Aquatic organisms from selected sites along the proposed trans-Alaska pipeline corridor, September 1970 to September 1972: U.S. Geol. Survey Basic-Data report, 23 p.

Nichols, D. R., and Buchanan-Banks, J. M., 1974, Seismic hazards and land-use planning: U.S. Geol. Survey Circ. $690,33 \mathrm{p}$.

Plafker, George, 1974, Preliminary geologic map of Kayak and Wingham Islands, Alaska: U.S. Geol. Survey open-file report 74-82, 1 sheet, scale 1:31,680.

Pratt, W. P., and Brobst, D. A., 1974, Mineral resources: Potentials and problems: U.S. Geol. Survey Circ. 698, 20 p.

Reed, B. L., and Lanphere, M. A., 1974, Chemical variations across the Alaska-Aleutian Range batholith: U.S. Geol. Survey Jour. Research, v. 2, no. 3, p. 343-352.

Reiser, H. N., Brosgé, W. P., Dutro, J. T., Jr., and Detterman,
R. L., 1974, Preliminary geologic map of tre Demarcation Point quadrangle, Alaska: U.S. Geol. Surrey Misc. Field Studies Map MF-610, 1 sheet, scale 1:200,000.

Richter, D. H., 1974, Reconnaissance geologic map of the Nabesna A-4 quadrangle, Alaska: U.S. Geo'. Survey Misc. Geol. Inv. Map I-789, 1 sheet, scale 1:63,360.

Richter, D. H., Matson, N. A., Jr., and Schmo'l, H. R., 1974, Reconnaissance geologic map of the Nabesna A-1 quadrangle, Alaska: U.S. Geol. Survey Misc. Geol. Inv. Map I-807, 1 sheet, scale 1:63,360.

Richter, D. H., and Schmoll, H. R., 1974, Geologic map of the Nabesna C-5 quadrangle, Alaska: U.S. Geol. Survey Geol. Quad. Map GQ-1062, 1 sheet, scale 1:63,360.

Schmoll, H. R., and Dobrovolny, Ernest, 1974, Construction materials map of Anchorage and vicinity, Alaska: U.S. Geol. Survey Misc. Geol. Inv. Map I-787-C, 1 sheet, scale 1:24,000.

1974, Foundation and excavation conditions map of Anchorage and vicinity, Alaska: U.S. Geo'. Survey Misc. Geol. Inv. Map I-787-D, 1 sheet, scale 1:24,000.

Scholl, D. W., Alpha, T. R., Marlow, M.S., and Buffington, E. C., 1974, Base map of the Aleutian-Bering Soa region: U.S. Geol. Survey Misc. Geol. Inv. Map I-879, 1 sheet, scale 1:2,500,000.

U.S. Geological Survey 1974, Aeromagnetic map of the Circle quadrangle, northeastern Alaska: U.S. Geol. Survey open-file report, 24 maps, scale $1: 63,360 ; 1$ map, scale 1:250,000.

1974, Aeromagnetic maps-

Eastern half of the Beaver quadrangle, northeastern Alaska: U.S. Geol. Survey open-file report, 12 maps, scale 1:63,360; 1 map, scale 1:250,000.

Eastern half of the Chandalar quadrangls, northeastern Alaska: U.S. Geol. Survey open-file report, 12 maps, scale 1:63,360; 1 map, scale 1:250,000.

Eastern half of the Livengood quadrangle, northeastern Alaska: U.S. Geol. Survey open-file report, 12 maps, scale 1:63,360; 1 map, scale 1:250,000.

1974, Seismic engineering program report, OctoberDecember 1974: U.S. Geol. Survey Circ. 713, 19 p.

U.S. Geological Survey, Topographic Division, 1974, Arctic A-1 quadrangle, Alaska: U.S. Geol. Survey, Topog. Ser., scale 1:63,360.

-1974, Arctic D-5 quadrangle, scale 1:63.360.

1974, Big Delta C-4 quadrangle, scale 1:63,360.

1974, Big Delta C-5 quadrangle, scale 1:63,360.

1974, Chandalar B-6 quadrangle, scale 1:63,360.

1974, Chandalar D-4 quadrangle, scale 1:63,360.

1974, Chandler Lake A-2 quadrangle, scale 1:63,360.

1974, Chandler Lake B-1 quadrangle, s sale 1:63,360.

1974, Chandler Lake B-2 quadrangle, s sale 1:63,360.

1974, Chandler Lake D-2 quadrangle, scale 1:63,360.

1974, Coleen D-1 quadrangle, scale 1:63,360.

1974, Coleen D-2 quadrangle, scale 1:63,360.

1974, Coleen D-3 quadrangle, scale 1:63,360.

1974, Coleen D-4 quadrangle, scale 1:63,360.

1974, Coleen D-5 quadrangle, scale 1:63,360.

1974, Coleen D-6 quadrangle, scale 1:63,360.

1974, Fairbanks A-2 quadrangle, scale 1:63,360.

1974, Fairbanks A-3 quadrangle, scale 1:63,360.

1974, Fairbanks A-4 quadrangle, scale 1:63,360.

1974, Fairbanks B-1 quadrangle, scale 1:63,360. 
1974, Fairbanks B-2 quadrangle, scale 1:63,360. 1974, Fairbanks B-3 quadrangle, scale 1:63,360. 1974, Fairbanks B-4 quadrangle, scale 1:63,360. 1974, Fairbanks C-1 quadrangle, scale 1:63,360. 1974, Fairbanks C-2 quadrangle, scale 1:63,360. 1974, Fiarbanks C-3 quadrangle, scale 1:63,360. 1974, Fiarbanks C-4 quadrangle, scale 1:63,360. -1974 , Fairbanks D-1 quadrangle, scale 1:63,360. 1974, Fairbanks D-2 quadrangle, scale 1:63,360. 1974, Fairbanks D-3 quadrangle, scale 1:63,360.

1974, Philip Smith Mountains A-4 quadrangle, scale 1:63,360.

1974, Philip Smith Mountains B-3 quadrangle, scale $1: 63,360$.

-1974, Philip Smith Mountains B-4 quadrangle, scale 1:63,360.

1974, Philip Smith Mountains B-5 quadrangle, scale $1: 63,360$.

-1974, Philip Smith Mountains C-2 quadrangle, scale $1: 63,360$.

-1974, Philip Smith Mountains C-5 quadrangle, scale 1:63,360.

-1974, Philip Smith Mountains D-1 quadrangle, scale $1: 63,360$.

1974, Philip Smith Mountains D-4 quadrangle, scale 1:63,360.

1974, Philip Smith Mountains D-5 quadrangle, scale $1: 63,360$.

1974, Sagavanirktok A-4 quadrangle, scale 1:63,360. -1974, Sagavanirktok B-2 quadrangle, scale 1:63,360. 1974, Sagavanirktok C-4 quadrangle, scale 1:63,360. 1974, Sagavanirktok C-5 quadrangle, scale 1:63,360.

1974, Table Mountain A-1 quadrangle, scale 1:63,360. 1974, Table Mountain A-2 quadrangle, scale 1:63,360. 1974, Table Mountain A-3 quadrangle, scale 1:63,360. 1974, Table Mountain A-4 quadrangle, scale 1:63,360. 1974, Table Mountain A-5 quadrangle, scale 1:63,360. 1974, Table Mountain B-1 quadrangle, scale 1:63,360. 1974, Table Mountain B-2 quadrangle, scale 1:63,360. 1974, Table Mountain B-3 quadrangle, scale 1:63,360. 1974, Table Mountain B-4 quadrangle, scale 1:63,360. 1974, Table Mountain B-5 quadrangle, scale 1:63,360. 1974, Umiat A-1 quadrangle, scale 1:63,360.
1974, Umiat A-2 quadrangle, scale 1:63,360. 1974, Umiat B-1 quadrangle, scale 1:63,360. 1974, Umiat B-2 quadrangle, scale 1:63,360. 1974, Umiat C-2 quadrangle, scale 1:63,360. 1974, Wiseman B-1 quadrangle, scale 1:63,360. 1974, Wiseman B-2 quadrangle, scale 1:63,360. 1974, Wiseman B-4 quadrangle, scale 1:63,360. -1974 , Wiseman B-5 quadrangle, scale 1:63,360. 1974, Wiseman $\mathrm{C}-1$ quadrangle, scale $1: 63,360$. 1974, Wiseman C-3 quadrangle, scale 1:63,360.

1974, Wiseman C-4 quadrangle, scale 1:63,360.

1974, Wiseman C-5 quadrangle, scale 1:63,360.

1974, Wiseman D-1 quadrangle, scale 1:68,360.

1974, Wiseman D-3 quadrangle, scale 1:68,360.

1974, Wiseman D-4 quadrangle, scale 1:69,360.

1974, Wiseman D-5 quadrangle, scale 1:63,360.

Water Resources Division, 1974, Quality of surface waters of the United States, 1969-Parts 12-16, North Pacific slope basins, Alaska, Hawaii, and other Pacific areas: U.S. Geol. Survey Water-Supply Paper 2150, 480 p.

Wallace, R. E., 1974, Goals, strategy, and tasks of the earthquake hazard reduction program: U.S. Geol. Survey Circ. 701, 26 p.

Worl, R. G., Van Alstine, R. E., and Heyl, A. V., 1974, Fluorite in the United States, exclusive of Hawaii: U.S. Geol. Survey Min. Inv. Res. Map MR-60, 1 sheet, scale $1: 3,168,000 ; 13 \mathrm{p}$.

Yehle, L. A., 1974, Reconnaissance engineering geology of Sitka and vicinity, Alaska, with emphasis on eraluation of earthquake and other geologic hazards: U.S. Geol. Survey open-file report $74-53,104 \mathrm{p}$.

Zenone, Chester, 1974, Geology and water resources of the Girdwood-Alyeska area, Alaska: U.S. Geol. S urvey openfile report, $24 \mathrm{p}$.

Zenone, Chester, and Donaldson, D. E., 1974, Water-quality and geohydrologic data at two sanitary landfill sites near Anchorage, Alaska: U.S. Geol. Survey open-file report, 1 sheet.

Zenone, Chester, Schmoll, H. R., and Dobrovolny, Ernest, 1974, Geology and ground water for land-use planning in the Eagle River-Chugiak area, Alaska: U.S. Gool. Survey open-file report $74-57,36 \mathrm{p}$. 
. 
. 